\title{
Assessment of the Idaho National Laboratory Remote-Handled Low-Level Waste Disposal Facility Vault Concrete Data
}

\author{
Annette L. Schafer
}

October 2017

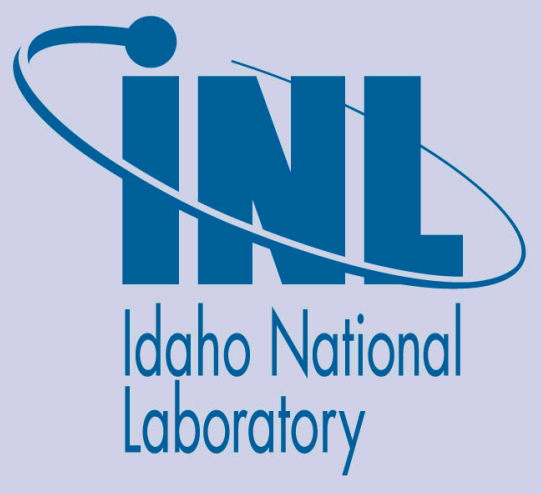

The INL is a U.S. Department of Energy National Laboratory operated by Battelle Energy Alliance 


\section{DISCLAIMER}

This information was prepared as an account of work sponsored by an agency of the U.S. Government. Neither the U.S. Government nor any agency thereof, nor any of their employees, makes any warranty, expressed or implied, or assumes any legal liability or responsibility for the accuracy, completeness, or usefulness, of any information, apparatus, product, or process disclosed, or represents that its use would not infringe privately owned rights. References herein to any specific commercial product, process, or service by trade name, trade mark, manufacturer, or otherwise, does not necessarily constitute or imply its endorsement, recommendation, or favoring by the U.S. Government or any agency thereof. The views and opinions of authors expressed herein do not necessarily state or reflect those of the U.S. Government or any agency thereof. 


\title{
Assessment of the Idaho National Laboratory Remote-Handled Low-Level Waste Disposal Facility Vault Concrete Data
}

\author{
Annette L. Schafer
}

October 2017

Idaho National Laboratory

Idaho Falls, Idaho 83415

http://www.inl.gov

Prepared for the

U.S. Department of Energy

Office of Nuclear Energy

Under DOE Idaho Operations Office

Contract DE-AC07-05ID14517 


\section{EXECUTIVE SUMMARY}

The Idaho National Laboratory has constructed a low-level waste (LLW) disposal facility to receive remote-handled (RH) LLW, defined as LLW having greater than $200 \mathrm{R} /$ hour on contact with the container, generated onsite or currently in storage onsite. The disposal facility is constructed as a series of reinforced concrete vertical vaults composed of a hexagonal base section with an integral cylindrical riser (i.e., pipe), upper riser section, and hexagonal plug. The vaults are arranged in four vault arrays to receive RH-LLW generated on-site at the Advanced Test Reactor Complex, the Naval Reactors Facility, and Materials and Fuels Complex. The facility will be operated in compliance with the requirements of U.S. Department of Energy (DOE) Order 435.1, "Radioactive Waste Management".

The performance assessment for the RH-LLW Disposal Facility is required to demonstrate the facility design will meet the performance objectives established for long-term protection of the public and environment following closure of the facility as outlined in DOE Order 435.1. Protectiveness of the facility in terms of the groundwater pathway is a function of the design features that control hydrologic and geochemical conditions within and below the vault system. The performance assessment's groundwater pathway model credits protection of the steel waste liners provided by interlocking reinforced concrete waste vaults, strength and stability of a final engineered cover that will be placed over the vaults when the facility is closed, and accounts for a cement-impacted geochemical environment within and below the vault system to inhibit corrosion of stainless steel waste containers (i.e., waste liners). To ensure the quality and performance of the concrete vault system, a thorough quality design and review process was implemented.

This document provides a summary of the concrete performance data collected during vault fabrication and installation. It also includes the process by which quality data were collected during vault fabrication and installation, inspection requirements, and a summary of resulting test data with the potential to impact vault system durability.

In addition, this report includes quantitative data collected on cured concrete samples poured for random concrete batches throughout the concrete component fabrication process. Quantitative data includes total porosity, bulk density, absorption, effective porosity, and gas-phase permeability. Chloride diffusivity data collected during the concrete mix selection process are also included for completeness.

Data show that the vault quality assurance program resulted in fabrication and installation of components with insignificant defects and damaged areas. Data collected on the cured concrete samples show gas-phase permeability and effective porosity are slightly higher than data used to select concrete mix designs. These differences are evaluated in the PA (DOE-ID 2017). 


\section{CONTENTS}

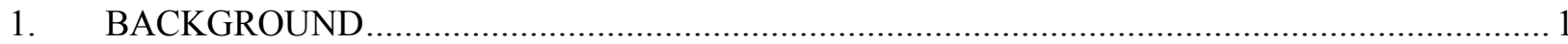

2. VAULT COMPONENT FABRICATION AND INSTALLATION QUALITY

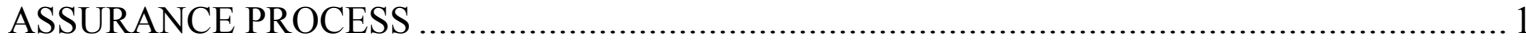

3. VAULT PERFORMANCE REQUIREMENTS AND CONCRETE MIX DESIGN .................... 3

3.1 Concrete Technical and Functional Requirements ...................................................... 3

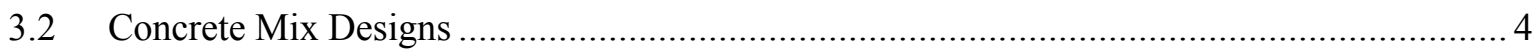

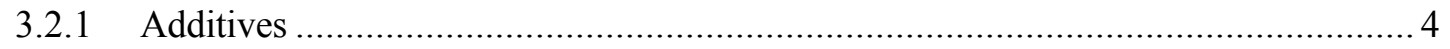

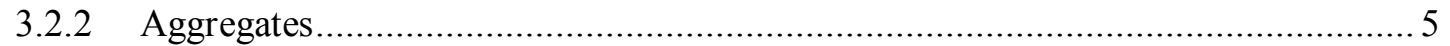

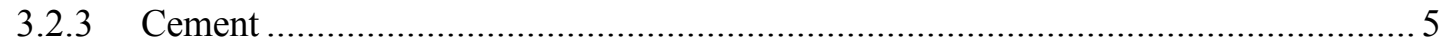

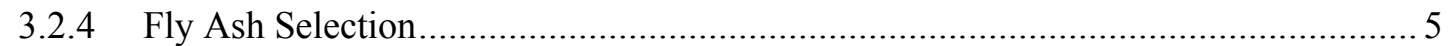

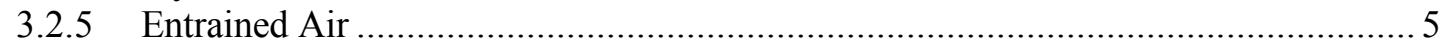

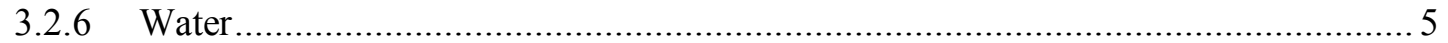

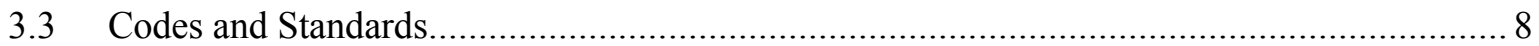

3.4 Environmental Conditions, Specified Exposure Design Limits, and Concrete Mix

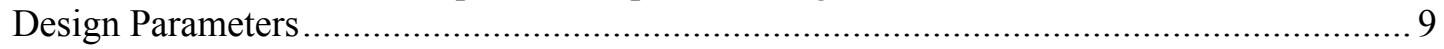

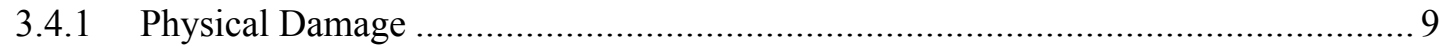

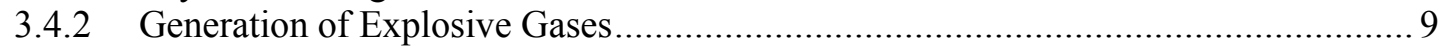

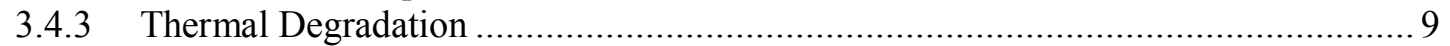

3.4.4 Aggressive Chemicals (Sulfate Exposure) ........................................................ 10

3.4.5 Exposure to Salts and Chemicals from Soil Water and Concrete (Chloride

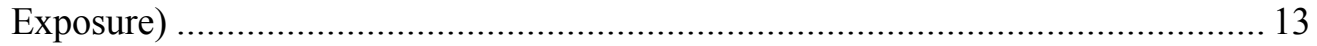

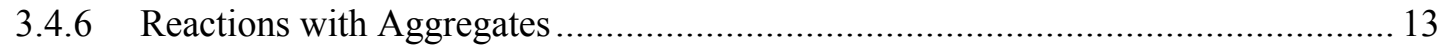

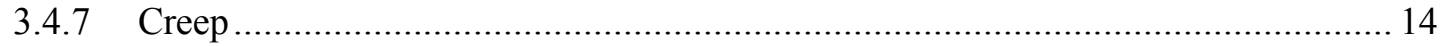

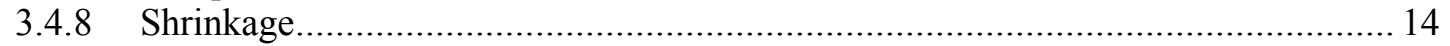

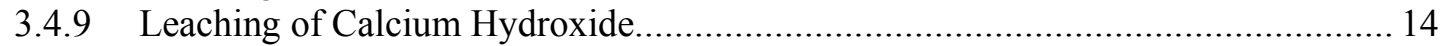

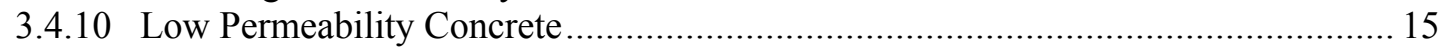

3.4.11 Carbonation and Corrosion of Reinforcing Materials ............................................ 15

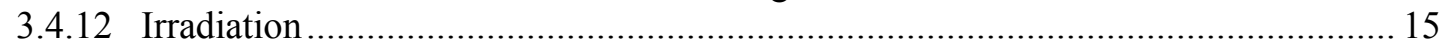

3.4.13 Managing Other Aging-Related Degradation Effects ........................................ 16

4. VAULT COMPONENT FABRICATION AND INSTALLATION QUALITY

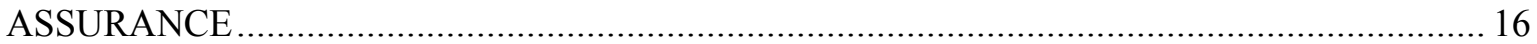

4.1 Concrete Inspection Criteria for Defects and Damage ............................................... 16

4.2 Justification for Acceptable Defects and Damaged Dimensions...................................... 19

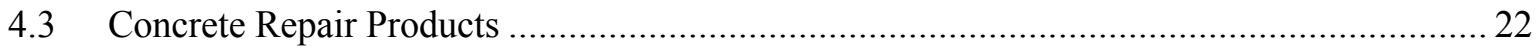

4.4 Concrete Defect and Damage Inspection Results ..................................................... 23 


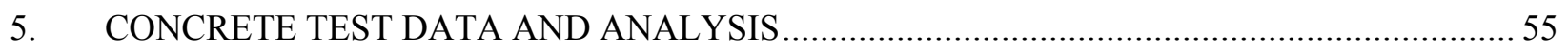

5.1 Concrete Density, Absorption, and Porosity Data......................................................... 56

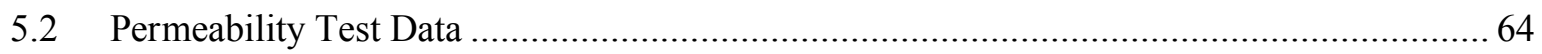

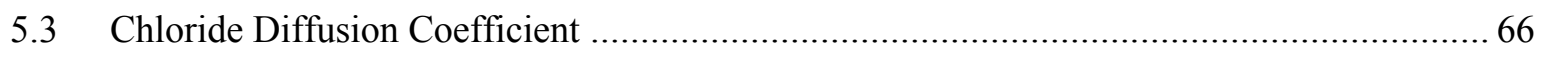

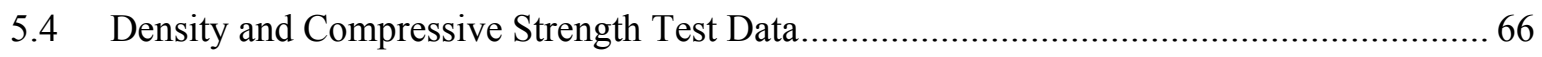

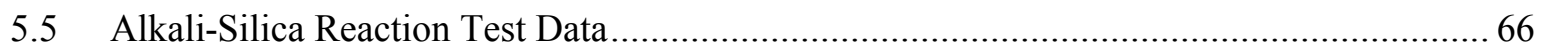

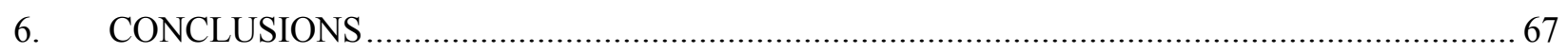

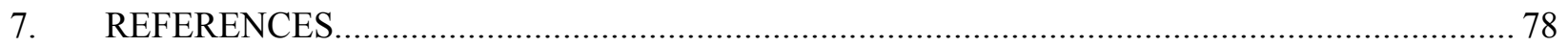

\section{FIGURES}

Figure 1. Concrete Mix Design \#2 for use in vault shield plugs, CVASs, and perimeter blocking installed above the frost line.

Figure 2. Concrete Mix Design \#3 for use in vault bases and vault upper risers installed below the frost line.

Figure 3. Test results for ASR showing average length change versus curing time with and without fly ash and lithium added to the concrete mix designs......

Figure 4. Example photograph of a bughole with measurement from SNR-027. The damage relative to the component dimensions is quantified in Table 9 and is insignificant.

Figure 5. Example photograph of honeycombing along tongue edge from SNR-087 (left) and along bottom edge from SNR-120 (right). The damage relative to the component dimensions is quantified in Table 9 and is insignificant.

Figure 6. Diagram and photos showing the dimensions for damage during shipping for LCC vault riser LCU-72 from NCR-013. The damage relative to the component dimensions is quantified in Table 9 and is insignificant.

Figure 7. Example photograph of spalling on plug LC-P29 before and after repair from SNR-108. The damage relative to the component dimensions is quantified in Table 9 and is insignificant.

Figure 8. Level 3 crack with a width 0.03-in. on component HFEF-U5 from SNR-056 (left) and portion of crack in component LC-U1, exceeding 0.01-in. width from SNR-077. Note the widest cracks occur on the portion of the component not credited for durability; the longest crack parallels a seam in the concrete form. The damage relative to the component dimensions is quantified in Table 9 and is insignificant. 
Figure 9. Total porosity as a function of hardened concrete hold time prior to testing.

Figure 10. Effective porosity versus total porosity for samples having the same batch ticket number.

Figure 11. Effective porosity and gas-phase permeability for test samples used to select the concrete mix designs from PLN-4952. 70

Figure 12. Gas-phase permeability at four different confining pressures. .71

Figure 13. Gas-phase permeability versus effective porosity. .73

Figure 14. Apparent chloride diffusion test data for Mix \#2A. .76

Figure 15. Apparent chloride diffusion test data for Mix \#3. .77

\section{TABLES}

Table 1. Summary of the freeze/thaw, sulfate, and chloride exposure class parameters according to ACI 318-11 and bounding design mix requirements.

Table 2. Thermal degradation requirements from ACI 318-11and measured batch test values. 10

Table 3. Building code requirements for structural concrete (ACI 318-11) for exposure to sulfate. 10

Table 4. RH-LLW site conditions, ACI 318-11 and SPC-1437 requirements, and concrete mix design values.

Table 5. Building code requirements for structural concrete (ACI 318-11) for exposure to chloride.

Table 6. Performance characteristics for Jet Set Concrete Repair grout.

Table 7. Composition information/ingredients for Jet Set Concrete Repair grout.

Table 8. Performance metrics for the MasterEmaco A660 admixture with sand/cement mortar samples.

Table 9. Summary of Level 3 defect and damage inspection results for individual components.

Table 10. Summary of Level 3 concrete component defects and damage by component type and vault array. .53

Table 11. Concrete density, absorption, and porosity data. .58

Table 12. Correlation between total porosity and other measured values from ASTM C642 data. 61

Table 13. Concrete porosity and density versus batch ticket data. 62

Table 14. Correlation data for concrete porosity as a function of concrete mix components. 63 
Table 15. Concrete density and compressive strength summary statistics by component type.

Table 16. Concrete permeability, porosity, and density data using API RP-40 methods.

Table 17. Correlation between measured values for the gas-phase permeability at 750-psi confining pressure and other API RP-40 data.

Table 18. Concrete permeability, porosity, and density sample batch ticket data................................ 74

Table 19. Correlation data for concrete gas-phase permeability at 500-psi confining pressure as a function of concrete mix components. 


\section{ACRONYMS}

ACI American Concrete Institute

API American Petroleum Institute

ASR alkali-silica reaction

ASTM American Society of Testing and Materials

BEA Battelle Energy Alliance

CAR corrective action report

CVAS cask-to-vault adapting structure

DOE U.S. Department of Energy

DOE-ID U.S. Department of Energy Idaho Operations Office

FTC facility transport container

HFEF Hot Fuel Examination Facility

INL Idaho National Laboratory

LCC large concept cask

LLW low-level waste

MFTC modified facility transport container

NCR nonconformance report

PA performance assessment

$\mathrm{RH} \quad$ remote-handled

SNR supplier nonconformance report

TFR technical and functional requirements 


\title{
Assessment of the Idaho National Laboratory Remote-Handled Low-Level Waste Disposal Facility Vault Concrete Data
}

\author{
1. BACKGROUND
}

A performance assessment (PA) for the Idaho National Laboratory (INL) Remote-Handled Low-Level Waste (RH-LLW) disposal facility is required to demonstrate the facility design will meet the performance objectives established for long-term protection of the public and environment following closure of the facility as outlined in DOE Order 435.1, "Radioactive Waste Management." Protectiveness of the facility in terms of the groundwater pathway is a function of the design features that control hydrologic and geochemical conditions within and below the vault system. The PA groundwater pathway model credits protection of the steel waste liners provided by interlocking reinforced concrete waste vaults, the strength and stability of a final engineered cover that will be placed over the vaults when the facility is closed, and accounts for a cement-impacted geochemical environment within and below the vault system to inhibit corrosion of stainless steel waste containers (i.e., waste liners). To ensure the quality and performance of the concrete vault system, a thorough quality design and review process was implemented.

This document provides an overview of the vault concrete-related design process, quality review process, test data, and quality review results.

\section{VAULT COMPONENT FABRICATION AND INSTALLATION QUALITY ASSURANCE PROCESS}

The RH-LLW Disposal Facility vault system (see SDD-410, "System Design Description for the Remote-Handled Low-Level Waste Disposal Vault System") was fabricated using the following design-build process:

1. The vault system installed at the RH-LLW Disposal Facility was designed and built according to the

"Technical and Functional Requirements (TFRs) for the Remote-Handled Low-Level Waste Disposal Project" (TFR-483 2015) and the "Design-Build-Operate Performance Specification for the

Remote-Handled Low-Level Waste Disposal Project" (for vault-specific requirements, see Section H of SPC-1437 2012). These documents provide technical requirements for the vault system in terms of functional capability. Functional requirements were specified based on assumptions made in the PA (DOE-ID 2012). Bids for the RH-LLW Disposal Facility project were solicited, reviewed, and the most acceptable bid was accepted.

2. A vault system design was then developed by AREVA and documented in the following:

- INL Drawings:
- 788644, Site Layout Plan, Revision 1
- 788645, 55-Ton Cask Vault Array, Revision 1
- 788648, NUPAC 14 210L Cask Vault Array, Revision 1
- 788651, HFEF-5 Cask and Large Concept Cask Vault Arrays, Revision 1
- 788652, HFEF-5 Cask and Large Concept Cask Vaults, Revision 2
- 788654, Modified FTC Cask Vault Array, Revision 1
- 788655, Modified FTC Cask Vaults, Revision 2
- 788657, Performance Assessment Vault Array, Revision 1
○ 788658, Installation Section and Detail, Revision 2 


$$
\begin{array}{ll}
\circ & 788766, \text { Excavation Plan, Revision } 1 \\
\circ & 788767, \text { Excavation Sections, Revision } 1 \\
\circ & 788768, \text { Grading Plan - Vault Yard, Revision } 1 \\
\circ & 788769, \text { Vault Yard Sections, Revision } 0 \\
\circ & 788770, \text { Vault Yard Section, Revision } 1 \\
\text { - } \quad \text { Vault System Structural Design (ECAR-2810) } \\
\text { - Vault Concrete Mix Design Report (PLN-4953). }
\end{array}
$$

3. The concrete design mix was submitted for testing by AREVA according to the following test plans:

- Vault Concrete Durability Test Plan (PLN-4989)

- Vault Compliance Test Plan (PLN-4956)

and documented in the following:

- Vault Concrete Safety-Related Design Parameters (PLN-4954)

- Vault Concrete Selection Report (PLN-4952).

Concrete test results were input into a concrete transport model for analysis conducted by Battelle Energy Alliance (BEA) (BEA is the prime contractor at the DOE-ID site) PA Development Team (i.e., Annette L. Schafer and A. Jeff Sondrup). This analysis was conducted to evaluate the total vault system's hydraulic performance and potential for concrete vaults to meet a 500-year period of performance. The analysis is documented as the Vault Hydraulic and Concrete Performance Analysis (which is an appendix in the PA).

4. The vault system design, test results, and performance analysis were all reviewed by BEA, DOE, DOE's technical reviewers, and the DOE LLW Disposal Facility Federal Review Group, who determined the vault system would be able to meet the 50 -year operational requirements for concrete density and strength and to provide reasonable expectations of being able to meet a 500-year vault system structural performance period as assumed in the PA.

5. Vault quality inspection test plans were then developed for use during vault component fabrication and vault system installation. These plans are documented in the following:

- Vault Component and Cask-To-Vault Adapting Structures (CVAS) Fabrication Quality Inspection Plan (PLN-5077)

- Vault Component and Cask-To-Vault Adapting Structures (CVAS) Fabrication Quality Inspection/Test Plan (PLN-5460, superseded PLN-5077)

- $\quad$ Vault Array Field Inspection, Sampling, and Testing Procedure (VDR-536953 2017).

6. The vaults were then fabricated according to the requirements of Construction Specification - Vault and Cask-to-vault Adapting Structure Fabrication for the RH LLW Disposal Project (SPC-1857). As vault components were being fabricated, the following occurred:

- Concrete used during fabrication was submitted for testing and subsequent analysis by the BEA PA development team

- Fabricated vault components were inspected for defects and/or damage using the PLN-5077 or PLN-5460 inspection test plan. Defects and damage were reported by the precast concrete contractor (i.e., Oldcastle) to AREVA on a corrective action report (CAR); the CAR was evaluated by the engineer-of-record; and a supplier nonconformance report (SNR), which included the technical justification for proposed corrective actions, was submitted to BEA for final disposition approval. 
- Components were either accepted as use-as-is, repaired using an approved repair procedure and transported to the disposal facility location, or they were rejected based on the BEA review of the SNR.

7. Prior to and during installation at the RH-LLW Disposal Facility location, vault components were again re-inspected according to requirements in Vault Array Field Inspection, Sampling, and Testing Procedure (VDR-536953 2017). This inspection plan provides defect and damage limits that are consistent with those in PLN-5077 and PLN-5460.

- If Level 2 or Level 3 damage occurred during transport (according to the criteria documented in SPC-1857), the components were evaluated using a process similar to that used during vault fabrication as follows:

- Damage was recorded by submitting a non-conformance report (NCR) or an SNR, including the technical evaluation for proposed corrective actions it was submitted by AREVA engineering to BEA for final disposition approval.

- If necessary, repairs using the approved repair procedure were made and a final inspection was performed to ensure the repairs were successful.

\section{VAULT PERFORMANCE REQUIREMENTS AND CONCRETE MIX DESIGN}

\subsection{Concrete Technical and Functional Requirements}

Early in the design process, it was determined that two concrete mix designs would meet the TFRs established to provide reasonable expectations of the vault system being able to meet a 500-year period of structural stability (SPC-1437). The TFRs for the vaults are as follows:

1. SPC-1437 H.1.C.1: Vaults shall be designed to be top-loading, reinforced, precast concrete cylinders with structurally supportive bases and a removable plug for top access and shielding. Unless specifically required, component sizes and thicknesses shall be based on the strength required to meet static and dynamic loading criteria during the disposal operation (Section H.1.K), dynamic and static loads imposed during operations on the interim soil cover (Section H.1.L.2), and static load of the engineered cover after facility closure (Section H.1.K.3).

2. SPC-1437 H.1.C.2: Vaults shall be precast concrete with a minimum 28-day compressive strength of 5,000 pounds per square inch (psi). Reinforcement shall be uncoated carbon steel.

3. SPC-1437 H.1.C.3: Material used in vault construction shall not adversely impact corrosion of stainless steel, Zircaloy, Inconel, carbon steel, or aluminum and shall not decrease the sorption capacity of resins beyond the range considered in the facility PA.

4. SPC-1437 H.1.C.5: Cement specifications shall consider the standards for resistance to degradation as specified by Annex 5 of the AMERICAN Society of Testing and Materials (ASTM) C1562-10, "Standard Guide for Evaluation of Materials Used in Extended Service of Interim Spent Nuclear Fuel Dry Storage," specifically, the following:

- $\quad$ ASTM C1562: Cement shall meet standards for freeze-thaw protection (A5.4.2), leaching of calcium hydroxide (A5.4.3), aggressive chemicals (A5.4.4), reactions with aggregates (A5.4.5), corrosion of embedded steel (A5.4.6), elevated temperatures (A5.4.7), irradiation (A5.4.8), creep (A5.4.9), shrinkage(A5.4.10), and managing aging-related degradation effects (A5.4.11).

- Concrete mix design should meet the requirements of American Concrete Institute (ACI) 318-08, Table 4.2.1 for the following exposure classes: 
- Freezing and thawing Class F2; air content should be determined in accordance with Table 4.3.1 of ACI 318-08

- Sulfate Class S2 (total sulfate in soil is in the range 22 to $87 \mathrm{mg} / \mathrm{kg}$, corresponding water soluble sulfate $\left(\mathrm{SO}_{4}\right)$ is $\left.200 \mathrm{ppm}\right)$

- Low permeability Class P1

- Corrosion protection of reinforcement Class C2.

In determining the mix designs, ACI 318-11 was used for concrete mix design because it was the latest code adopted by STD-139, superseding ACI 318-08, and referenced in SPC-1437.

5. SPC-1437 H.1.C.6: Aggregates, including rock, pozzolans, fly ash, and slag, shall be selected to minimize alkali-aggregate reaction (which includes alkali-carbonate reaction and alkali-silica reaction [ASR]) using the guidance provided in ACI 201.2R.

6. SPC-1437 H.1.C.7: All materials used in the vault system, including materials placed beneath and between individual vaults and between the steel liner and concrete vault to reduce the void space, shall withstand the expected radiolytic dose ranges provided in the facility PA without degrading during the first 500 years and shall not be degraded during the first 500 years via chemical or biological means. Degradation in this context refers to creation of additional void space in the concrete that would increase the concrete porosity and permeability. Examples of materials subject to radiolytic degradation include polymers, plastics, rubber, and so forth.

7. SPC-1437 H.1.C.8: All materials used in the vault system, including materials placed beneath and between individual vaults and between the steel liner and concrete vault to reduce the void space, shall not adversely impact the corrosion of stainless steel, Zircaloy, Inconel, carbon steel, or aluminum and shall not decrease the sorption capacity of resins, sub-base, and alluvium beneath the vaults beyond the range considered in the facility PA.

\subsection{Concrete Mix Designs}

Two mix designs selected for use (Mix \#2 and Mix \#3) are detailed in the Vault Concrete Mix Design Report (PLN-4953) and are shown in Figures 1 and 2. The mix design report includes the requirements for all additives, aggregates, cement, fly ash, entrained air, and water quality. The two mix designs differ only in inclusion of an air-entraining admixture in Mix \#2 used to protect the vault shield plugs, cask-tovault adapting structures (CVASs), and perimeter blocking from potential freeze-thaw damage (see Section 3.2). Components installed below the frost line include vault upper riser sections and bases. These components were fabricated using Mix \#3, which did not include the air-entraining admixture. The two mix designs were selected in consideration of the TFRs (Section 3.1), applicable codes and standards (Section 3.3), and environmental conditions expected in and adjacent to the RH-LLW Disposal Facility vaults (Section 3.4).

\subsubsection{Additives}

Additives specified for Mix \#2 and Mix \#3 were certified to be compatible with TFRs for concrete and with all other admixtures, including the following:

- Air-entraining admixture: ASTM C260 certified by the manufacturer to be compatible with other required admixtures

- Chemical admixtures: Certified by the manufacturer to be compatible with other admixtures and to not contain calcium chloride or more than $0.15 \%$ chloride ions or other salts by weight of admixture:

- Accelerating admixture: ASTM C 494, Type C

- High-range water reducer: Conform to ASTM C 494, Type A or F 
- Lithium/ASR inhibitor: ASTM C 494, Type S.

\subsubsection{Aggregates}

To ensure aggregates met the ASTM C33 specification, all aggregates were supplied by the specified supplier from the same pit location. The suppliers are Burns Concrete and Aggregate for the 3/4-in. course aggregate and Rhodehouse for the sand fine aggregate. These pits are both Idaho Transportation Department-approved pits, which helped ensure aggregate consistency and the aggregates met the following specifications:

- Normal-weight aggregates: ASTM C33 (except as modified by Precast Concrete Institute MNL 116), C.20 with maximum coarse aggregate size of 3/4-in.

- Source Bn-152-c (Burns Concrete) is located in Sec. 11, T. 1 N., R. 37 E., B.M., South of Idaho Falls, Idaho

- Source Jf-103-c (Rhodehouse Golden Valley Pit) is located in a portion of the SE, SW \& SW, SE of Sec. 15, \& NE, NW \& NW, NE of Sec. 22 T. 4 N., R. 37 E., B.M., North of Idaho Falls, Idaho.

\subsubsection{Cement}

The cement (i.e., Type II with C3A less than 5\%) was selected based on the most conservative requirements discussed in the Vault Concrete Selection Report (PLN-4952). A sulfate category S2 requires Type II cement with a $\mathrm{C}_{3} \mathrm{~A}$ less than $5 \%$. The specified cement was supplied by Ashgrove and meets ASTM C150, Type II with $\mathrm{C}_{3} \mathrm{~A}$ less than $5 \%$ requirements.

\subsubsection{Fly Ash Selection}

Fly ash was used to help achieve low permeability and porosity in the concrete. It also provides increased resistance to ASR in concrete as discussed in Vault Concrete Selection Report (PLN-4952). To ensure consistent fly ash, Class F Bridger fly ash (supplied by Headwaters) was specified. The following requirements apply:

- ASTM C618, Class F, except loss on ignition shall be less than $2 \%$

- Strength activity index at 28 days shall be at least $95 \%$ of the control

- $\mathrm{Sum}$ of $\mathrm{SiO}_{2}$ plus $\mathrm{Al}_{2} \mathrm{O}_{3}$ plus $\mathrm{Fe}_{2} \mathrm{O}_{3}$ shall be greater than $77 \%$.

\subsubsection{Entrained Air}

The air quantity in concrete Mix \#2 has been selected based on the most conservative requirements of ACI 318. A freeze-thaw category F2 requires an air content of $6 \% \pm 1.5 \%$. The air quantity was reduced by $1 \%$ for concrete with a 28 -day compressive strength of 5,000 psi or greater as specified in SPC-1437.

\subsubsection{Water}

Water used in fabrication of the vault components was taken from a municipal water supply. The water/cement ratio was specified to be less than 0.38 (see Table 4 in the Vault Concrete Selection Report, PLN-4952). 


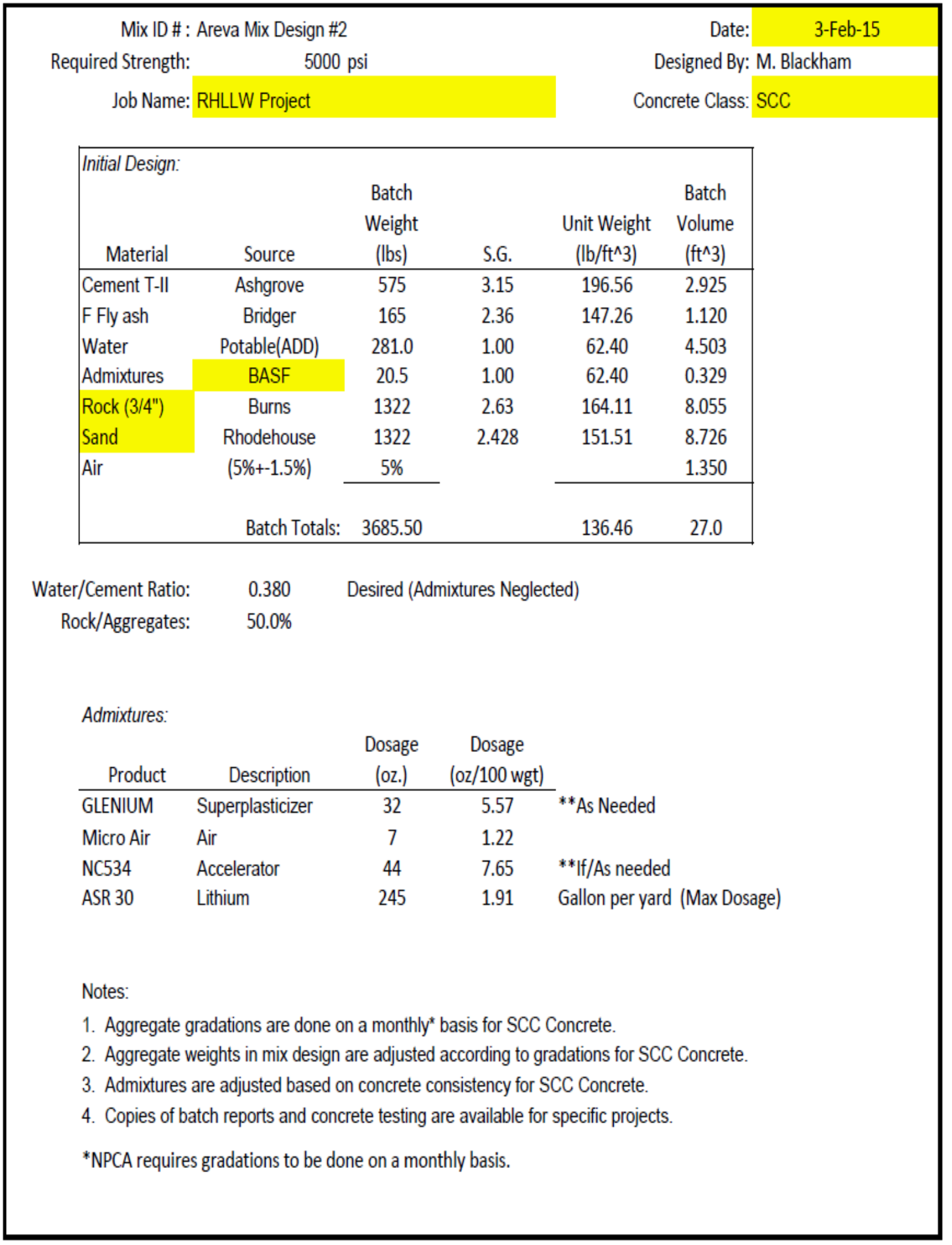

Figure 1. Concrete Mix Design \#2 for use in vault shield plugs, CVASs, and perimeter blocking installed above the frost line. 
Mix ID \# : Areva Mix Design \#3

Required Strength:

$5000 \mathrm{psi}$

Job Name: RHLLW Project
Date:

3-Feb-15

Designed By: M. Blackham

Concrete Class: SCC

\begin{tabular}{|c|c|c|c|c|c|}
\hline \multicolumn{6}{|l|}{ Initial Design: } \\
\hline \multirow[b]{2}{*}{ Material } & \multicolumn{3}{|c|}{ Batch } & \multicolumn{2}{|r|}{ Batch } \\
\hline & Source & $\begin{array}{c}\text { Weight } \\
\text { (lbs) }\end{array}$ & S.G. & $\begin{array}{c}\text { Unit Weight } \\
\left(\mathrm{lb} / \mathrm{ft}^{\wedge} 3\right)\end{array}$ & $\begin{array}{c}\text { Volume } \\
\left(\mathrm{ft}^{\wedge} 3\right)\end{array}$ \\
\hline Cement T-II & Ashgrove & 580 & 3.15 & 196.56 & 2.951 \\
\hline F Fly ash & Bridger & 160 & 2.36 & 147.26 & 1.086 \\
\hline Water & Potable(ADD) & 274.0 & 1.00 & 62.40 & 4.391 \\
\hline Admixtures & BASF & 20.6 & 1.00 & 62.40 & 0.330 \\
\hline Rock (3/4") & Burns & 1385 & 2.63 & 164.11 & 8.439 \\
\hline Sand & Rhodehouse & 1383 & 2.428 & 151.51 & 9.128 \\
\hline Air & No Air Spec. & $3 \%$ & & & 0.675 \\
\hline & Batch Total & 3802.56 & & 140.83 & 27.0 \\
\hline
\end{tabular}

Water/Cement Ratio: $\quad 0.370 \quad$ Desired (Admixtures Neglected)

Rock/Aggregates: $\quad 50.0 \%$

Admixtures:

\begin{tabular}{llccl} 
Product & \multicolumn{1}{c}{ Description } & $\begin{array}{c}\text { Dosage } \\
\text { (oz.) }\end{array}$ & $\begin{array}{c}\text { Dosage } \\
\text { (oz/100 wgt) }\end{array}$ & \\
\cline { 1 - 4 } GLENIUM & Superplasticizer & 40 & 6.90 & ${ }^{* *}$ As Needed \\
NC534 & Accelerator & 44 & 7.59 & ${ }^{* *}$ If /As needed \\
ASR 30 & Lithium & 245 & 1.91 & Gallon per yard (Max Dosage)
\end{tabular}

Notes:

1. Aggregate gradations are done on a monthly $y^{\star}$ basis for SCC Concrete.

2. Aggregate weights in mix design are adjusted according to gradations for SCC Concrete.

3. Admixtures are adjusted based on concrete consistency for SCC Concrete.

4. Copies of batch reports and concrete testing are available for specific projects.

*NPCA requires gradations to be done on a monthly basis.

Figure 2. Concrete Mix Design \#3 for use in vault bases and vault upper risers installed below the frost line. 


\subsection{Codes and Standards}

The following codes and standards used in development of the concrete mix design were determined to be applicable based on standard building practices augmented to meet nuclear facility TFRs:

- "Guide to Durable Concrete" (ACI 201.2R-08, reapproved 2011) was used as a guide to specify the considerations and requirements for the concrete mix design provided in SPC-1437.

- "Building Code Requirements for Structural Concrete and Commentary" (ACI 318-11 2011) provides exposure categories for consideration in selecting concrete mix components for the vaults. In some cases, SPC-1437 provided more restrictive specifications than would have been used following the recommendations of ACI 318-11.

- "Code Requirements for Nuclear Safety-Related Concrete Structures and Commentary" (ACI 349-06) provides concrete design recommendations used in high-temperature environments. Other requirements of ACI 349 are very similar to those of ACI 318-11. As discussed in subsequent sections, the temperature environment in the vaults does not result in modifications to the limits specified in Table 1.

Table 1 summarizes the exposure categories specified by SPC-1437 and corresponding recommendations of ACI 318-11.

Table 1. Summary of the freeze/thaw, sulfate, and chloride exposure class parameters according to ACI 318-11 and bounding design mix requirements.

\begin{tabular}{|c|c|c|c|c|}
\hline $\begin{array}{c}\text { Exposure } \\
\text { Class }^{1}\end{array}$ & $\begin{array}{l}\text { Maximum } \\
\text { Water/Cement } \\
\text { Ratio (w/cm) }\end{array}$ & $\begin{array}{c}\text { Minimum } \\
\text { Compressive } \\
\text { Strength at } \\
\text { 28-days (f'c) } \\
\text { (psi) }\end{array}$ & \multicolumn{2}{|c|}{ Additional Minimum Requirements } \\
\hline F1 & 0.45 & 2,500 & Air content per ACI 318-11, Table 4.4.1 & NA \\
\hline $\mathrm{F} 2$ & 0.45 & 4,500 & Air content per ACI 318-11, Table 4.4.1 & NA \\
\hline S2 & 0.45 & 4,500 & $\begin{array}{l}\text { Cementitious materials }^{2} \text { - } \\
\text { Type V cement or Type II with } \mathrm{C}_{3} \mathrm{~A} \\
\text { (tricalcium aluminate) content less than } 5 \%\end{array}$ & $\begin{array}{l}\text { Calcium chloride } \\
\text { admixture not permitted }\end{array}$ \\
\hline $\mathrm{C} 2$ & 0.40 & 5,000 & $\begin{array}{l}\text { Maximum water-soluble chloride ion }(\mathrm{Cl}) \\
\text { content in concrete by weight of cement for } \\
\text { reinforced concrete }=0.15 \%\end{array}$ & $\begin{array}{l}\text { Related provisions of } \\
\text { ACI 318-11 }\end{array}$ \\
\hline \multicolumn{5}{|c|}{ Most restrictive requirements: } \\
\hline \multicolumn{5}{|c|}{$\begin{array}{l}\text { Maximum water/cement ratio: } 0.40 \\
\text { Minimum 28-day compressive strength: } 5,000 \mathrm{psi} \\
\text { Cementitious materials: Type II cement with } \mathrm{C}_{3} \mathrm{~A} \text { content less than } 5 \% \\
\text { Maximum chloride ion content: } 0.15 \% \text { by weight of cement }\end{array}$} \\
\hline
\end{tabular}




\subsection{Environmental Conditions, Specified Exposure Design Limits, and Concrete Mix Design Parameters}

Section 4 of the Vault Concrete Selection Report (PLN-4952) summarizes the environmental conditions expected at the RH-LLW disposal vault location and correlates them to the design limits specified in SPC-1437 and to the selected concrete mix parameters for the two selected concrete mix designs. The environmental conditions and concrete mix parameters related to performance requirements are discussed in the following subsections.

\subsubsection{Physical Damage}

Physical damage to the disposal vaults was most likely to occur during transportation or lifting and handling activities during construction or operations. Components suffering physical damage during transportation and construction were inspected and determined to be acceptable (i.e., use-as-is), rejected or repaired subject to requirements of the Vault Compliance Test Plan (PLN-4956) and Construction Specification - Vault Fabrication for the RH LLW Disposal Project (SPC-1857).

\subsubsection{Generation of Explosive Gases}

Material safety data sheets in the Vault Concrete Mix Design Report (PLN-4953) are provided for chemical admixtures as an indication of the chemical composition and associated hazards. All admixtures have National Fire Protection Association Hazard codes of 0 for fire and reactivity.

\subsubsection{Thermal Degradation}

Low-temperature (i.e., freeze-thaw) conditions and high-temperature effects (from radiolytic exposure) were considered in the design. The resistance of concrete vault components to freeze-thaw degradation was addressed through a combination of vault system design, which placed the vault base and riser sections below the frost line with the perimeter blocks, vault plugs, and CVASs above the frost line and through the use of an air-entraining admixture for the components placed above the frost line. According to ACI 318-11, the following four freeze-thaw exposure classes for concrete are defined:

- F0: Concrete not exposed to freezing-and-thawing cycles.

- F1: Concrete exposed to freezing-and-thawing cycles and occasional exposure to moisture.

- F2: Concrete exposed to freezing-and-thawing cycles and continuous contact with moisture.

- F3: Concrete exposed to freezing and thawing cycles, in continuous contact with moisture, and where exposure to deicing minerals is expected.

Using these definitions, the vault risers and bases are Class F0 and, in the absence of deicing minerals, the components above the frost line fall in the F2 class. The worst-case exposure conditions of Class F3 can be avoided during operations by not using deicing minerals near the vaults. Therefore, two concrete mix designs were specified, with Mix \#2 containing an air-entraining admixture for use in components placed above the frost line and Mix \#3 designated for components installed below the frost line. The requirements for concrete Classes F2 and F3 from ACI 318-11, Section 4.4.1 and Tables 4.3.1 and 4.4.1 are met by both concrete mix designs as indicated in Table 2. 
Table 2. Thermal degradation requirements from ACI 318-11 and measured batch test values.

\begin{tabular}{lccc}
\hline \multicolumn{1}{c}{ Parameter } & $\begin{array}{c}\text { Concrete Mix \#2 Values for } \\
\text { Components above the Frost Line } \\
\text { (Perimeter Pieces, CVAS, and } \\
\text { Shielding Plugs) }\end{array}$ & $\begin{array}{c}\text { Concrete Mix \#3 Values for below } \\
\text { Frost Line Components (Risers and } \\
\text { Bases) }\end{array}$ & w/cm $\leq 0.38^{*}$ \\
\hline $\begin{array}{l}\text { Maximum water } \\
\text { cement ratio (w/cm) }\end{array}$ & $\mathrm{w} / \mathrm{cm} \leq 0.38^{*}$ & $5,000 \mathrm{psi}$ & $\mathrm{NA}$ \\
$\begin{array}{l}\text { Minimum 28-day } \\
\text { compressive strength }\end{array}$ & $5,000 \mathrm{psi}$ & $\mathrm{NA}$ & $>6,000 \mathrm{psi}$ \\
$\begin{array}{l}\text { Air content (3/4-in. } \\
\text { maximum aggregate } \\
\text { size) }\end{array}$ & $5 \% \pm 1.5 \%$ & & $5.8 \%$ for Mix 2 \\
\hline *There are allowable tolerances on w/cm per the applicable standards referenced in Vault Compliance Test Plan (PLN-4956). & $3.0 \%$ for Mix 3
\end{tabular}

For high-temperature environments, ACI 349 places limits on the long-term temperature exposure of in-place concrete to $150^{\circ} \mathrm{F}$. The limit is permitted to increase to $180^{\circ} \mathrm{F}$ if actual concrete compressive strengths are $115 \%$ of the specified 28 -day compressive strength. Temperatures inside the storage vaults are expected to be slightly above the average soil temperature for INL, which is close to $55^{\circ} \mathrm{F}$. The maximum short-term high temperature inside the vaults is about $85^{\circ} \mathrm{F}$ (DOE-ID 2012). The minimum strength from test results included in Vault Concrete Safety-Related Design Parameters (PLN-4954, Appendix A) from samples of design mixes was 6,520 psi, which is $130 \%$ of the specified 28 -day design compressive strength.

\subsubsection{Aggressive Chemicals (Sulfate Exposure)}

Four sulfate exposure classes exist for concrete in ACI 318-11, which are determined by the percent mass of $\mathrm{SO}_{4}$ in the soil and the dissolved $\mathrm{SO}_{4}$ in the water (ppm) as shown in Table 3.

Table 3. Building code requirements for structural concrete (ACI 318-11) for exposure to sulfate.

\begin{tabular}{lcc}
\hline Class & $\begin{array}{c}\text { Water Soluble Sulfate }\left(\mathrm{SO}_{4}\right) \text { in Soil } \\
(\text { Percent by Mass) }\end{array}$ & $\begin{array}{c}\text { Dissolved Sulfate }\left(\mathbf{S O}_{4}\right) \text { in Water } \\
(\mathbf{p p m})\end{array}$ \\
\hline $\mathrm{S} 0$ & $\mathrm{SO}_{4}<0.1$ & $\mathrm{SO}_{4}<150$ \\
$\mathrm{~S} 1$ & $0.1 \leq \mathrm{SO}_{4} \leq 0.2$ & $150 \leq \mathrm{SO}_{4}<1,500$ \\
S2 & $0.2 \leq \mathrm{SO}_{4} \leq 2$ & $1,500 \leq \mathrm{SO}_{4} \leq 10,000$ \\
\hline
\end{tabular}

SPC-1437 provided a range for total sulfate in soil equal to 22 to $87 \mathrm{mg} / \mathrm{kg}$, with a maximum of $0.009 \%$. Therefore, INL soils correspond to ACI Class S0. However, designing to ACI 318-11 Class S2 was required by SPC-1437, Section 3.2.2, even though it is not required based on the potential for exposure to sulfate in the soils. To provide additional chemical resistance, Type II concrete $\mathrm{C}_{3} \mathrm{~A}$ (i.e., tricalcium aluminate) concentrations less than 5\% were specified for Mix \#2 and Mix \#3 concrete designs as recommended by ACI 318-11. The other concrete mix design requirements (i.e., water/cement ratio and 28-day compressive strength) for Class S2 are the same as those for Class F2.

SPC-1437 H.1.C.3: Material used in vault construction shall not adversely impact corrosion of stainless steel, Zircaloy, Inconel, carbon steel, or aluminum and shall not decrease the sorption capacity of resins beyond the range considered in the facility PA. 
Table 4. RH-LLW site conditions, ACI 318-11 and SPC-1437 requirements, and concrete mix design values.

\begin{tabular}{|c|c|c|c|c|c|c|}
\hline $\begin{array}{l}\text { Requirement } \\
\text { Description }\end{array}$ & $\begin{array}{c}\text { Report } \\
\text { Discussion } \\
\text { (Section in } \\
\text { PLN-4952) } \\
\end{array}$ & $\begin{array}{c}\text { Bounding Range of } \\
\text { Conditions }\end{array}$ & $\begin{array}{c}\text { SPC-1437 } \\
\text { Bounding } \\
\text { Parameters } \\
\end{array}$ & $\begin{array}{l}\text { ACI Bounding } \\
\text { Parameters }\end{array}$ & Method of Substantiation & $\begin{array}{c}\text { Concrete Mix } \\
\text { Parameters } \\
\end{array}$ \\
\hline $\begin{array}{l}\text { 500-year structural } \\
\text { stability }\end{array}$ & General & NA & $\begin{array}{l}500 \text {-year } \\
\text { structural stability }\end{array}$ & None & $\begin{array}{l}\text { Analysis using service life } \\
\text { prediction software }\end{array}$ & $\begin{array}{l}\text { See durability } \\
\text { parameters listed } \\
\text { below and in Table } 5\end{array}$ \\
\hline $\begin{array}{l}\text { Corrosion of waste } \\
\text { containers and } \\
\text { subsequent release } \\
\text { of radionuclides }\end{array}$ & General & $\begin{array}{l}\text { Concrete that has not been } \\
\text { degraded has a high } \mathrm{pH}\end{array}$ & $\begin{array}{l}\text { No impact to } \\
\text { corrosion of waste } \\
\text { containers }\end{array}$ & None & Mix design documentation & All \\
\hline $\begin{array}{l}\text { Generation of } \\
\text { explosive gases }\end{array}$ & & $\begin{array}{l}\text { Potential for explosion in } \\
\text { vaults }\end{array}$ & $\begin{array}{l}\text { No explosive gas } \\
\text { generation }\end{array}$ & None & $\begin{array}{l}\text { Material safety data sheets for } \\
\text { admixtures and cement }\end{array}$ & $\begin{array}{l}\text { Minimal volatile } \\
\text { organic compounds in } \\
\text { components }\end{array}$ \\
\hline \multirow[t]{2}{*}{$\begin{array}{l}\text { Freeze-thaw } \\
\text { resistance }\end{array}$} & \multirow[t]{2}{*}{3.4 .3} & $\begin{array}{l}\text { Vault plug, CVASs, and } \\
\text { perimeter and end blocks } \\
\text { above frost line for up to } \\
50 \text { years }\end{array}$ & $\begin{array}{l}\text { ACI } 318 \text { Class F2 } \\
\text { for plugs, F0 for } \\
\text { below grade vault } \\
\text { components }\end{array}$ & \multirow[t]{2}{*}{$\begin{array}{l}\text { For Class F2: } \\
\mathrm{w} / \mathrm{cm} \leq 0.4 \\
\mathrm{f}^{\prime} \mathrm{c} \geq 4500 \mathrm{psi} \\
\text { Air content per ACI } \\
\text { Table } 4.4 .1\end{array}$} & \multirow[t]{2}{*}{$\begin{array}{l}\text { Ensure design mix for the } \\
\text { vault plug complies with or is } \\
\text { better than bounding } \\
\text { parameters ACI } 318 \text { Exposure } \\
\text { Class F2 }\end{array}$} & \multirow[t]{2}{*}{$\begin{array}{l}\mathrm{w} / \mathrm{cm} \leq 0.38 \\
\mathrm{fc} \geq 5,000 \mathrm{psi} \\
\text { air content } 5 \% \pm 1.5 \%\end{array}$} \\
\hline & & $\begin{array}{l}\text { Other vault components } \\
\text { below frost line }\end{array}$ & & & & \\
\hline \multirow[t]{2}{*}{ Carbonation } & \multirow[t]{2}{*}{4.9} & Pore water chemistry & 500 -year & \multirow[t]{2}{*}{ None } & \multirow[t]{2}{*}{ Concrete carbonation model } & \multirow{2}{*}{$\begin{array}{l}\text { Permeability of } \\
\text { concrete and } \\
\text { surrounding } \\
\text { environment }\end{array}$} \\
\hline & & $\begin{array}{l}\text { Unsaturated concrete pores } \\
\text { and voids }\end{array}$ & structural stability & & & \\
\hline \multirow{3}{*}{$\begin{array}{l}\text { Leaching of calcium } \\
\text { hydroxide (related } \\
\text { to water flow) }\end{array}$} & \multirow[t]{3}{*}{3.4 .9} & Pore water chemistry & ACI 318 Exposure & \multirow{3}{*}{$\begin{array}{l}\text { For Class } \mathrm{P} 1: \\
\mathrm{w} / \mathrm{cm} \leq 0.5 \\
\mathrm{fc}^{\prime} \geq 4,000 \mathrm{psi}\end{array}$} & \multirow{3}{*}{$\begin{array}{l}\text { Ensure design mix complies } \\
\text { with or is better than } \\
\text { bounding parameters for ACI } \\
318 \text { Exposure Class P1 }\end{array}$} & \multirow{3}{*}{$\begin{array}{l}\mathrm{w} / \mathrm{cm} \leq 0.38 \\
\mathrm{fc}^{\prime} \geq 5,000 \mathrm{psi}\end{array}$} \\
\hline & & Unsaturated concrete pores & Class P1 & & & \\
\hline & & and voids & $\begin{array}{l}\text { ASTM A1562 } \\
\text { Guidelines }\end{array}$ & & & \\
\hline \multirow[t]{2}{*}{$\begin{array}{l}\text { Sulfate attack } \\
\text { resistance }\end{array}$} & \multirow[t]{2}{*}{3.4 .4} & $\begin{array}{l}\text { Total sulfate in soils } 5 \text { to } \\
86 \mathrm{mg} / \mathrm{kg}(0.0005 \text { to } \\
0.0086 \% \text { by mass })\end{array}$ & $\begin{array}{l}\text { ACI } 318 \text { Exposure } \\
\text { Class S2 }\end{array}$ & \multirow{2}{*}{$\begin{array}{l}\text { w/cm } \leq 0.45 \\
\text { fc'}^{\prime} \geq 4,500 \text { psi } \\
\text { Type V cement or } \\
\text { Type II cement with } \\
\mathrm{C}_{3} \mathrm{~A}<5 \%\end{array}$} & \multirow{2}{*}{$\begin{array}{l}\text { Ensure design mix complies } \\
\text { with or is better than } \\
\text { bounding parameters for ACI } \\
318 \text { Exposure Class S2 }\end{array}$} & \multirow{2}{*}{$\begin{array}{l}\text { w/cm } \leq 0.38 \\
\text { fc'}^{\prime} \geq 5,000 \text { psi } \\
\text { Type V cement or } \\
\text { Type II cement with } \\
\mathrm{C}_{3} \mathrm{~A}<5 \%\end{array}$} \\
\hline & & $\begin{array}{l}\text { Equates to ACI } 318 \\
\text { Exposure Class S0 for soil }\end{array}$ & & & & \\
\hline $\begin{array}{l}\text { Reactions with } \\
\text { aggregate }\end{array}$ & 3.4 .6 & & $\begin{array}{l}\text { ASTM A1562 } \\
\text { Guidelines }\end{array}$ & $\begin{array}{l}\text { None in the } \\
\text { reference ACI } \\
\text { standards }\end{array}$ & $\begin{array}{l}\text { Aggregate ASR potential } \\
\text { testing }\end{array}$ & $\begin{array}{l}\text { Design mix uses a } \\
\text { durable aggregate, } \\
\text { lithium admixture, and } \\
\text { fly ash to eliminate the } \\
\text { potential for ASR }\end{array}$ \\
\hline
\end{tabular}


Table 4. (continued).

\begin{tabular}{|c|c|c|c|c|c|c|}
\hline $\begin{array}{c}\text { Requirement } \\
\text { Description }\end{array}$ & $\begin{array}{c}\text { Report } \\
\text { Discussion } \\
\text { (Section in } \\
\text { PLN-4952) } \\
\end{array}$ & $\begin{array}{c}\text { Bounding Range of } \\
\text { Conditions } \\
\end{array}$ & $\begin{array}{c}\text { SPC-1437 } \\
\text { Bounding } \\
\text { Parameters } \\
\end{array}$ & $\begin{array}{l}\text { ACI Bounding } \\
\text { Parameters } \\
\end{array}$ & Method of Substantiation & $\begin{array}{c}\text { Concrete Mix } \\
\text { Parameters } \\
\end{array}$ \\
\hline $\begin{array}{l}\text { Corrosion protection } \\
\text { of reinforcing steel } \\
\text { (water and chloride } \\
\text { ingress) }\end{array}$ & 3.4 .5 & $\begin{array}{l}\text { RH-LLW site soil chloride } \\
\text { range }=5 \text { to } 83 \mathrm{mg} / \mathrm{kg} \\
(0.0005 \text { to } 0.0083 \% \text { by } \\
\text { mass }) \\
\text { Equates to ACI } 318 \\
\text { Exposure Class C1 }\end{array}$ & $\begin{array}{l}\text { ACI } 318 \text { Exposure } \\
\text { Class P1 and C2 }\end{array}$ & $\begin{array}{l}\mathrm{w} / \mathrm{cm} \leq 0.4 \\
\mathrm{fc}^{\prime} \geq 5,000 \mathrm{psi} \\
\text { Maximum } \\
\text { water-soluble } \\
\text { chloride ion percent } \\
\text { by weight of cement } \\
\leq 0.15\end{array}$ & $\begin{array}{l}\text { Design mix complies with or } \\
\text { is better than ACI bounding } \\
\text { parameters }\end{array}$ & $\begin{array}{l}\mathrm{w} / \mathrm{cm} \leq 0.38 \\
\mathrm{fc}^{\prime} \geq 5,000 \mathrm{psi}\end{array}$ \\
\hline $\begin{array}{l}\text { Elevated } \\
\text { temperatures }\end{array}$ & 4.3 & $\begin{array}{l}\text { Temperature inside the } \\
\text { disposal vaults slightly } \\
\text { above soil temperatures } \\
\text { (i.e., about } 55^{\circ} \mathrm{F} \text { ); likely } \\
\text { short-term maximum less } \\
\text { than } 85^{\circ} \mathrm{F}\end{array}$ & $\begin{array}{l}\text { ASTM A1562 } \\
\text { Guidelines }\end{array}$ & $\begin{array}{l}\text { ACI } 349 \text { E. } 4 \\
\text { requires that } \\
\text { long-term } \\
\text { temperature be } \\
\text { limited to } 150^{\circ} \mathrm{F} \text {. }\end{array}$ & $\begin{array}{l}\text { Comparison of vault internal } \\
\text { temperature to ACI } 349 \text { limit }\end{array}$ & None \\
\hline Irradiation & 3.4 .12 & $\begin{array}{l}60,000 \mathrm{R} / \text { hour maximum } \\
\text { source term }\end{array}$ & $\begin{array}{l}\text { ASTM A1562 } \\
\text { Guidelines }\end{array}$ & None & & $\begin{array}{l}\text { Not directly applicable } \\
\text { to the design mix }\end{array}$ \\
\hline Creep & 3.4 .7 & $\begin{array}{l}\text { Ratio of design maximum } \\
\text { compressive stress to } \\
\text { design compressive } \\
\text { strength }=0.48 \text { for vault } \\
\text { walls }\end{array}$ & $\begin{array}{l}\text { ASTM A1562 } \\
\text { Guidelines }\end{array}$ & None & $\begin{array}{l}\text { No long-term creep cracking } \\
\text { expected due to fairly low } \\
\text { stress-to-strength ratio and the } \\
\text { fact that the stresses are } \\
\text { mainly compressive in nature }\end{array}$ & $\begin{array}{l}\text { Not applicable to the } \\
\text { design mix }\end{array}$ \\
\hline Shrinkage & 3.4 .8 & $\begin{array}{l}\text { Drying conditions during } \\
\text { curing }\end{array}$ & $\begin{array}{l}\text { ASTM A1562 } \\
\text { Guidelines }\end{array}$ & $\begin{array}{l}\text { A typical shrinkage } \\
\text { limit is } 0.040 \%\end{array}$ & $\begin{array}{l}\text { Inspection for shrinkage } \\
\text { cracks }\end{array}$ & $\mathrm{w} / \mathrm{cm} \leq 0.38$ \\
\hline $\begin{array}{l}\text { Managing } \\
\text { aging-related effects }\end{array}$ & 3.4 .13 & Site conditions & $\begin{array}{l}\text { ASTM A } 1562 \\
\text { Guidelines }\end{array}$ & Not applicable & $\begin{array}{l}\text { Restrict use of deicing salts or } \\
\text { other deleterious chemicals } \\
\text { during operations in the } \\
\text { vicinity of the disposal vaults }\end{array}$ & $\begin{array}{l}\text { Applicable to } \\
\text { operations and } \\
\text { maintenance }\end{array}$ \\
\hline
\end{tabular}




\subsubsection{Exposure to Salts and Chemicals from Soil Water and Concrete (Chloride Exposure)}

Exposure to chloride ions in solution will be mitigated during operations through restrictions on using deicing salts near the vaults. For unmitigated chloride exposure, ACI 318-11 defines the following three chloride exposure classes for concrete:

- $\mathrm{C} 0$ - Concrete dry or protected from moisture

- $\mathrm{C} 1$ - Concrete exposed to moisture, but not to external sources of chlorides

- $\mathrm{C} 2$ - Concrete exposed to moisture and an external source of chlorides from deicing chemicals, salt, brackish water, seawater, or spray from these sources.

The American Geotechnics Report (American Geotechnics 2011) reports the pore water chloride mass concentration at the RH-LLW site to be $0.0083 \%$. The pore water chloride concentration falls in the ACI 318-11 Class of C0. However, SPC-1437 specified the more stringent design criteria of C1. During most of the 500-year design life, the vaults will be covered with a final engineered cover that will further protect the vaults from excessive moisture.

ACI 318-11, Table 4.3.1 provides the Class $\mathrm{C} 1$ requirements reproduced in Table 5, which are met by the maximum $\mathrm{w} / \mathrm{cm}$ ratio of 0.38 required for freeze/thaw protection and by the minimum 5,000-psi compressive strength specified in SPC-1437.

Table 5. Building code requirements for structural concrete (ACI 318-11) for exposure to chloride.

\begin{tabular}{|c|c|c|}
\hline Requirement & Class C1 & Class C2 \\
\hline Maximum water cement ratio $(\mathrm{w} / \mathrm{cm})$ & NA & $0.40^{*}$ \\
\hline Minimum design 28-day compressive strength & $2,500 \mathrm{psi}$ & $5,000 \mathrm{psi}$ \\
\hline $\begin{array}{l}\text { Maximum water-soluble chloride ion }\left(\mathrm{Cl}^{-}\right) \text {content in concrete, percent by weight of cement where the } \\
\text { allowable water-soluble chloride ion content that is contributed from the ingredients (including water, } \\
\text { aggregates, cementitious materials, and admixtures) is determined on the concrete mixture by ASTM } \\
\text { C1218 at an age between } 28 \text { and } 42 \text { days }\end{array}$ & $0.30 \%$ & $0.15 \%$ \\
\hline
\end{tabular}

* Maximum w/cm ratio less than 0.38 was specified by both mix designs for freeze/thaw protection.

\subsubsection{Reactions with Aggregates}

Aggregate sources across eastern Idaho have been characterized in the report entitled, "Lithologic Characterization of Active ITD Aggregate Sources and Implications for Aggregate Quality" (Report RP-212 2014; prepared for the Idaho Transportation Department by the Idaho Geological Survey). The sources from which the aggregate were extracted are pit BN-155C and pit JF-103C as specified in the Vault Concrete Mix Design Report (PLN-4953).

The BN-152C pit from which the course aggregate was taken is about 2.5 miles south of the $\mathrm{BN}-155 \mathrm{C}$ pit just south of Idaho Falls. These pits are equal distances from the Snake River and are located along HW-91. The BN-155C pit is characterized in the RP-212 report as alluvium of Snake River glacial outwash with $65 \%$ quartzite, $10 \%$ rhyolite and dacite, $10 \%$ sandstone, and less than $1 \%$ obsidian. This mineralogy will be durable in concrete.

Fine aggregate came from the JF-103C pit, which is a volcanic lithic sand containing $15 \%$ quartzite, $40 \%$ rhyolite and dacite, $20 \%$ basalt and gabbro, with $25 \%$ chert, chalk, and obsidian. This aggregate is dominated by durable minerals and will contribute to durable concrete.

As determined in the RP-212 report and confirmed in concrete mix design trials for RH-LLW vault components, these aggregate sources are subject to ASR with concrete. To mitigate the ASR potential, the concrete mix designs for vault components shown in the Vault Concrete Mix Design Report (PLN-4953) (i.e., a low-alkali cement, a pozzolan [fly ash], and a lithium-based chemical admixture) were used as 
recommended by ACI 318-11. With these specific admixtures, the potential for ASR was reduced to $0.02 \%$ average length change as shown in Figure 3 (reproduced from Attachment 2 of the Vault Concrete Selection Report, PLN-4952).

\subsubsection{Creep}

Sustained stresses in the RH-LLW vaults are low relative to concrete design strength and are compressive in nature. The ratio of design maximum compressive stress to design compressive strength $=0.48$ for the vault walls according the Vault System Structural Design (ECAR-2810). The maximum compressive stress includes stress from short-term or dynamic loading, which does not contribute to creep. Because of the fairly low sustained stress level and the mainly compressive nature of the stress, cracks due to creep are not expected.

\subsubsection{Shrinkage}

The design mix for the RH-LLW vaults has a low quantity of excess water (the design water cementitious ratio is 0.38 ); therefore, the vaults should not experience shrinkage cracking. Degradation (i.e., cracks) caused by curing shrinkage was observed and corrected in the acceptance inspection of the vault components as specified in the Vault Compliance Test Plan (PLN-4956).

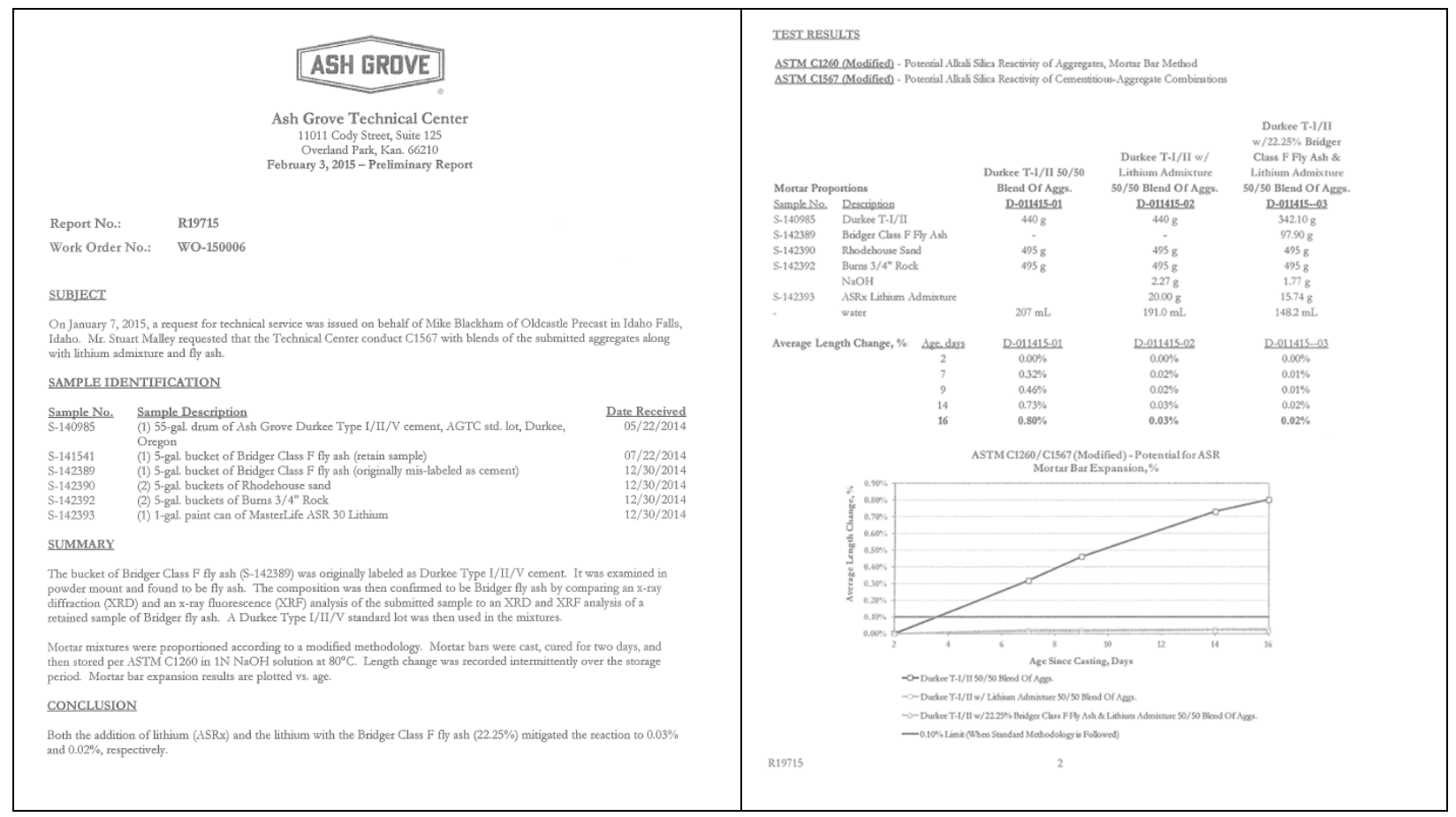

Figure 3. Test results for ASR showing average length change versus curing time with and without fly ash and lithium added to the concrete mix designs.

\subsubsection{Leaching of Calcium Hydroxide}

Water passing through cracks, joints, pores, and voids in the cured concrete may slowly dissolve calcium compounds in concrete. Water can either migrate through the concrete via Darcy Flow, capillary imbibition, or by diffusion. The dominant mechanism is, in part, dictated by permeability of the cured concrete and by water availability, which is dictated by materials (i.e., backfill and gravel infill) surrounding the vault components. Saturation of the vault area components has been quantitatively assessed in the "Vault Hydraulic and Concrete Performance Analyses" provided in the revised PA (DOE-ID 2017). Based on materials selected for vault infill materials, the pore space adjacent to the concrete and within the concrete should be near residual moisture content (i.e., the moisture content 
should be less than $1 \%$ ). This means that significant leaching is not expected to occur because significant quantities of water will not be adjacent to or available for imbibition into the concrete components.

\subsubsection{Low Permeability Concrete}

ACI 318-11 defines a P0 and P1 permeability exposure class. For exposure Class P0, there are no provided recommendations. The requirements for Class P1 from Table 4.3.1 in ACI 318-11 are as follows:

- $\quad$ Maximum water cement ratio $(\mathrm{w} / \mathrm{cm})=0.50$

- Minimum design 28-day compressive strength $=4,000 \mathrm{psi}$.

ACI 318-11 Class P1 concrete is required by SPC-1437 (Section 3.2.2). Based on test data during selection of the two concrete mix designs, gas-phase permeability was measured after 28 days of curing at $3.4 \times 10^{-8} \mathrm{~cm} / \mathrm{sec}$ (see Attachment 7 in the Vault Concrete Selection Report, PLN-4952). Gas-phase permeability is typically higher than permeability to water due to the Klinkenberg effect (Klinkenberg 1941) This effect is due to slip flow of gas at pore walls, which enhances gas flow when pore sizes are very small, resulting in gas permeability being larger than water permeability by several times to one order of magnitude. In addition, the permeability of concrete decreases with curing time, with the decrease larger for concrete containing fly ash. For this test value, the combined effect should reduce concrete permeability to within the $1 \times 10^{-10} \mathrm{~cm} / \mathrm{sec}$ range reported for mature good quality concrete (Thouvenot et al. 2013).

Quantitative permeability values for cured test cylinders collected during vault fabrication are provided in Section 5.2.

\subsubsection{Carbonation and Corrosion of Reinforcing Materials}

As discussed in the Vault Concrete Selection Report (PLN-4952), exposure conditions, primarily the pore-water saturation, have a significant effect on the depth of carbonation and the amount of $\mathrm{CO}_{2}$ absorbed over time. In general, carbonation only occurs when water saturation is between 40 and $90 \%$. If saturation is too low, then there is insufficient water in the pores for $\mathrm{CO}_{2}$ to dissolve into to form the carbonic acid needed to react with the calcium compounds. If the saturation is too high, then the pore network is full of water and ingress of carbon dioxide is inhibited. When saturation is in a moderate range, conditions are ideal to promote a greater carbonation depth and a higher $\mathrm{CO}_{2}$ absorption. As discussed in the Assessment of Idaho National Laboratory Remote-Handled Low-Level Waste Disposal Facility Hydraulic Performance (INL 2017), the hydraulic drainage system installed adjacent and between the vault arrays is expected to keep the moisture content below 1.5\% (saturation less than 9\%), except for very short (i.e., 1 to 2-day) time periods following extreme precipitation events. After installation of the final infiltration-reducing engineered cover, moisture content should be even lower adjacent to the vaults.

Normal carbonation results in a decrease of porosity, making the carbonated paste stronger. It increases both the compressive and tensile strength. Initially, the $\mathrm{pH}$ of pore water in the concrete should be in excess of 13. As carbonation occurs, depletion of calcium hydroxide will cause the concrete pore solution to drop below $\mathrm{pH} 13$, with the $\mathrm{pH}$ reaching as low as 8 for fully carbonated concrete. As discussed in the PA (DOE-ID 2017), at a pH 13, corrosion of reinforcement is inhibited and it would take centuries for reinforcement in the vault components to corrode sufficiently to cause significant concrete cracking/degradation.

\subsubsection{Irradiation}

The maximum design-level radiation exposure level for the Naval Reactors Facility-activated metal vaults is provided in TFR-483 as: "The maximum unshielded dose rate of the waste that will be disposed of at the remote-handled LLW facility will be 60,000 R/hour." The quantitative effects on concrete 
resulting from this exposure rate are evaluated in an Appendix to the PA entitled, "Vault Hydraulic and Concrete Performance Analyses" (DOE-ID 2017).

\subsubsection{Managing Other Aging-Related Degradation Effects}

The shield plugs are the only portions of the vaults that may be accessible for replacement or repair due to degradation. However, they are the portion of the vault system that is more likely to see an effect from exposure to atmosphere, freeze-thaw effects, salt exposure, or other environmental concerns.

Restrictions will be placed on operations, prohibiting the use of deicers or similar products in the vicinity of the disposal vaults.

\section{VAULT COMPONENT FABRICATION AND INSTALLATION QUALITY ASSURANCE}

The vault component inspection process was established in Engineering Change Notice SPC-1857 (Engineering Change Notice \#8) to the Construction Specification-Vault and Cask-to-Vault Adapting Structure Fabrication for the RH-LLW Disposal Project (SPC-1857). Inspection results for defects and damage to vault concrete components were evaluated by an independent inspection agency using forms provided in Vault Component and Cask-To-Vault Adapting Structures (CVAS) Fabrication Quality Inspection/Test Plan (PLN-4952 superseded by PLN-5460). Concrete units that did not comply with requirements of the design documents or were damaged were identified as nonconforming and a CAR or nonconformance report (NCR) was prepared (See Section 4.1 for criteria related to nonconforming requirements.). The CAR or NCR was evaluated by the engineer-of-record and an SNR that included technical justifications for proposed corrective actions was submitted to BEA for approval of the final disposition. Units not accepted for use-as-is or approved for repair were discarded and replaced. Repairs were permitted if structural adequacy, serviceability, and durability of units were not impaired.

\subsection{Concrete Inspection Criteria for Defects and Damage}

The independent inspection agency categorized all damage (i.e., chipping or spalling) and defects (i.e., cracks, bugholes, honeycombing, air bubble marks, or seam offsets) into one of three levels to determine the approved reporting path as follows:

- Level 1 - Acceptable defect/damage. No action is necessary unless additional criteria are noted.

- Level 2 - Minor defect/damage. These repairs may be performed by the fabricator using an approved procedure for repairs without requiring a nonconformance being written by the fabricator.

- Level 3 - Nonconforming defect/damage. These items require a CAR be prepared by the fabrication contractor. The CAR will be evaluated by the engineer-of-record and an SNR that includes technical justification for proposed corrective actions will be submitted to BEA for final disposition approval.

All cracks and repairs, regardless of level, were documented, and if a defect or damage was not addressed by the criteria given as follows, it was considered to be a Level 3 nonconforming defect/damage. Defects and damaged areas were evaluated according to the following from PLN-5460, which superseded earlier more restrictive reporting criteria contained in PLN-5077:

- $\quad$ Top edge (tongue base flat surface of bases and upper risers)

- Chipping/spalling: unlimited length, $\leq 1$-in. deep and $\leq 1$-in. horizontal along the flat, and $\leq 1$-in. vertical along the barrel. Level 1 no repair except to remove rough edges that will impede fit-up of the next component.

- Chipping/spalling: unlimited length, $\leq 1 / 2$-in. deep and $\leq 2$-in. horizontal along the flat, and $\leq 2$-in. vertical along the barrel. Level 1 no repair except to remove rough edges that will impede fit-up of the next component. 
- Chipping/spalling: unlimited length, $>1 / 2$-in. but $\leq 1$-in. deep and $>1$-in. but $\leq 2$-in. horizontal, or $>1$-in. but $\leq 2$-in.vertical along the barrel. Level 2 minor repair.

- Chipping/spalling: unlimited length, $>1$-in. deep or $>2$-in. horizontal along the flat, or $>2$-in. vertical along the barrel. Level 3 write CAR.

- Bubble marks: $\leq 1 / 2$-in. deep. Level 1 no repair.

- Bubble marks: $>1 / 2$-in. deep, but $\leq 1$-in. deep. Level 2 minor repair.

- Bubble marks: >1-in. deep. Level 3 write CAR.

- Top tongue of bases and upper risers

- Unlimited length, $\leq 1$-in. deep. Level 1 no repair, except to remove rough edges that will impede fit-up of the next component.

- Unlimited length, >1-in. deep. Level 3 write CAR.

- Bottom edge of all components

- Chipping/spalling: unlimited length, $\leq 1$-in. deep and $\leq 1$-in. horizontal along the flat, and $\leq 1$-in. vertical along the barrel. Level 1 no repair, except to remove rough edges that will impede fit-up of the next component.

- Chipping/spalling: unlimited length, $\leq 1 / 2$-in. deep and $\leq 2$-in. horizontal along the flat. and $\leq 2$-inch vertical along the barrel. Level 1 no repair, except to remove rough edges that will impede fit-up of the next component.

- Chipping/spalling: unlimited length, $>1 / 2$-in. but $\leq 1$-in. deep, and $>1$-in. but $\leq 2$-in. horizontal, or $>1$-in. but $\leq 2$-in. vertical along the barrel. Level 2 minor repair.

- Chipping/spalling: unlimited length, $>1$-in. deep or $>2$-in. horizontal along the flat, or $>2$-in. vertical along the barrel. Level 3 write CAR.

- Bugholes and bubble marks (all concrete components, excluding top edge and top tongue)

- $\quad$ Single surface void $\leq 1 / 2$-in. deep. Level 1 no repair.

- $\quad$ Single surface void $>1 / 2$-in. deep but $\leq 1$-in. deep. Level 2 minor repair.

- $\quad$ Single surface void $>1$-in. deep. Level 3 write CAR.

- Honeycombing (all concrete components excluding top edge and top tongue) (defined as voids typically characterized by presence of aggregate)

- Honeycombing with void depths $\leq 1 / 2$-in. deep. Level 1 no repair.

- Honeycombing with void depths $>1 / 2$-in. deep, but $\leq 1$-in. deep. Level 2 minor repair.

- Honeycombing with void depths $>1$-in. deep. Level 3 write CAR.

- Lift lug area (all concrete components)

- Within a 6 -in. radius from the center of the lift lug and $\leq 1 / 2$-in. deep. Level 1 no repair.

- Within a 6-in. radius from the center of the lift lug and $>1 / 2$-in. deep but $\leq 1$-in. deep. Level 2 minor repair.

- Within a 6-in. radius from the center of the lift lug and $>1$-in. deep. Level 3 write CAR.

- Cracks - general (all concrete components)

- $\quad \leq 0.01$-in. width (unlimited length). Level 1 no repair; however, for visible cracks $>0.005$-in. width and $\leq 0.01$-in. width mark ends of cracks and write date using a permanent marker.

- Note: Visible cracks are cracks that are observed under normal lighting conditions without magnification and without adding solutions or other means to illuminate the crack. $>0.01$-in. width (any length). Level 3 write CAR.

- Cracks - spider (all concrete components) 
- $\quad$ Spider cracks (three or more visible cracks, all within 2 in. of each other at some point) 0.005 -in. width (any length). Level 1 no repair; however, for visible spider cracks $\leq 0.005$-in. in width mark the extent of the spider crack by circling the area and write date using a permanent marker.

- Note: Visible cracks are cracks that are observed under normal lighting conditions without magnification and without adding solutions or other means to illuminate the crack.

- Spider cracks (three or more visible cracks all within 2 in. of each other at some point) $>0.005$-in. width (any length). Level 3 write CAR.

- Plug edges

- Unlimited length, $\leq 1$-in. perpendicular from the edge and $\leq 1 / 2$-in. deep. Level 1 no repair, except to remove rough edges.

- Unlimited length, $>1$-in. but $\leq 1$ 1/2-in. perpendicular from the edge and $>1 / 2$-in. but $\leq 1$-in. deep. Level 2 minor repair.

- Unlimited length, $>1$ 1/2-in. perpendicular from the edge or $>1$-in. deep. Level 3 write CAR.

- Hex base

- If the base has a defect/damage that does not expose rebar or loose aggregate, repair is left to the discretion of the fabricator based on their quality assurance/quality control program. Level 1 no repair or Level 2 minor repair.

- If the base has a defect/damage that exposes rebar or loose aggregate. Level 3 write CAR.

- Perimeter/end block or end wall edges

- Unlimited length, $\leq 1$ 1/2-in. perpendicular from the edge and $\leq 1 / 2$-in. deep. Level 1 no repair.

- Unlimited length, $\leq 1$ 1/2-in. perpendicular from the edge and $>1 / 2$-in. deep, but $\leq 1$-in. deep. Level 2 minor repair.

- Unlimited length, $>1$ 1/2-in. perpendicular from the edge or $>1$-in. deep. Level 3 write CAR.

- Vault barrel seams

- Seam offset $\leq 1 / 4$-in. Level 1 no repair, except rub or grind seams as needed to eliminate protrusions.

- $\quad$ Seam offset $>1 / 4$-in. Level 3 write CAR.

- Drilled lift holes between partition voids on the facility transfer container (FTC or equivalent, MFTC) base and upper section vault components)

- Chipping/spalling: a $\leq 6$-in. radius from the center of the drilled lift hole (applies to both sides of the hole) and $\leq 11 / 8$-in. total depth from both sides combined (i.e., minimum wall thickness of remaining concrete at any horizontal point in the hole is $\geq 3$-in.). Level 1 no repair.

- Chipping/spalling: apply the following criterial independently to both sides of the hole: $>6$-in., but $\leq 12$-in. radius from the center of the drilled lift hole and $\leq 3 / 8$-in. deep. Level 1 no repair.

- Chipping/spalling: unlimited radius, $\geq 11 / 8$-in. total depth from both sides combined (i.e., minimum wall thickness of remaining concrete at any horizontal point in the hole is $<3$-in.). Level 3 write CAR.

- Chipping/spalling: Apply the following criterial independently to both sides of the hole: $>6$-in., but $\leq 12$-in. radius from the center of the drilled lift hole and $>3 / 8$-in. deep. Level 3 write CAR.

- Chipping/spalling: >12-in. radius from center of the drilled lift hole, any depth. Level 3 write CAR. 


\subsection{Justification for Acceptable Defects and Damaged Dimensions}

Acceptable defects and damage dimensions were defined based on the vault component fabricator's experience and technical evaluation of the concrete longevity evaluated Vault Hydraulic and Concrete Performance Analysis (an appendix in the PA). This approach was taken because building codes and standards reviewed by the project were not developed to ensure the 500 -year performance period specified by SPC-1437. The following justifications are provided for accepting the Level 1 defects without repair, repairing the Level 2 defects, and addressing the Level 3 defects as special cases:

- Effect of Surface Defects and Damage on Concrete Longevity and Long-Term Structural Performance. Surface defects are inherently common in concrete. Typical surface defects include bugholes, honeycombing, and bubble marks that are typically surface voids caused by air entrapped between the form and the concrete volume (but not within the concrete volume that is unable to escape during casting).

- Level 1 criteria were established to identify minor defects or damaged areas occurring on the vault component concrete surfaces. Left unrepaired, these damaged areas are not expected to have a significant impact on concrete durability or structural performance of the vault components.

- Level 2 criteria were established to identify repairable areas. Defects and damage falling into this criterion increases the potential of moisture penetration into the components. This moisture has the potential of freezing within the concrete matrix and causing further damage, has the potential of reaching and causing corrosion of steel reinforcement, or has potential of increasing other chemical degradation rates (i.e., carbonation). Thus, repairing defects and damage falling into this category was mandated in order to minimize the potential for moisture penetration. For surface defects, this assessment applies to damage such as bugholes, honeycombing, bubble marks, chipping, spalling, and damage in the lift lug area.

For surface defect damage, the limiting dimension is the depth because it most directly affects the degree of moisture penetration into the concrete, shielding capability, and concrete longevity characteristics. For the allowable unrepaired loss of thickness due to Level 1 conditions, a thickness loss of 0.5 -in. results in an $8.4 \%$ decrease in the 6 -in. wall thickness of the vault upper riser or base components and a $0.84 \%$ decrease in plug thickness while maintaining a 2 " thick cover over the reinforcement. This loss would have minimal impact to the radiation analysis provided ECAR-2747 and an acceptable loss to concrete durability. Repairs made for Level 2 conditions replaced the lost concrete, resulting in no decrease in shielding, strength, or concrete durability, or adverse conditions that affect vault fit-up, container fit, or vault alignment.

The allowable repairable area for repairable bugholes, honeycombing, bubble marks, chipping, and spalling was initially defined in inspection criteria provided in PLN-5077, although the area of the defect is not limiting. The specified areal extents for allowable repairs corresponded to specifications in ACI 301, where surface defects larger than 1-1/2 in. wide are recommended to be repaired for an as-cast surface finish of SF-1.0 (which is the lowest surface criteria for exposed concrete surfaces).

Level 3 criteria. Defects and damage exceeding the Level 2 criteria triggered a CAR. Repairs for Level 3 conditions were evaluated on a case-by-case basis. For the special case of damage occurring to the drilled lift holes in the MFTC bases and upper sections, the allowable spalling depth was defined in ECAR-3852, which determined the minimum required concrete thickness for lifting the components. 
- Effect of Cracks: It is normal for concrete to have very small (e.g., hairline, microscopic, pattern, map, and crazing) cracking where the cracks are so small they typically cannot be seen without wetting the concrete surface. There are also more visible cracks that typically form as a result of thermal stresses occurring in the concrete during curing caused by the outside of the component curing at a faster rate than the inside. Curing cracks are more common in thicker components and were expected to be seen in higher numbers on the 5-ft thick vault plugs as opposed to the vault riser sections having 6-in thick vault walls. The following are taken from references related to this type of cracking:

- ACI 224R states, "In general, microcracking that occurs before loading has little effect on the compressive strength of the concrete" and "surface cracking can appear as pattern cracking and results from a decrease in volume of the material near the surface or increase in volume below the surface."

- The National Ready Mix Concrete Association has done research and has created publications talking about this type of cracking. One publication states the following, "Crazing cracks are sometimes referred to as shallow map or pattern cracking. They do not affect the structural integrity of concrete and rarely do they affect durability or wear resistance." These small hairline cracks are typically so small and have virtually no depth that to see them typically requires water or some other solution to be applied to the concrete. Per the National Ready Mix Concrete Association, this type of cracking does not affect the structural integrity of the concrete. These cracks are so small they cannot be accurately measured with common equipment.

There are three primary reasons to be concerned with microcracking. The first is related to moisture infiltration that could impact long-term vault performance. The second is related to microcracking being a starting point for development of larger cracks (as stated in ACI 446.1R-91). The third reason is related to the potential for a reduction in compressive strength that could impact both short-term and long-term performance of the vault components.

- Level 1 and 2 criteria.

To establish the allowable crack width, a literature search was performed, resulting in a project-determined allowable crack width of $0.01 \mathrm{in}$. or less in the vault components. The justification for this is as follows and is based on the potential for cracks of this width to autogenously heal if located in a favorable environment:

- Autogenous healing of concrete is reviewed by Neville (2002). Neville's literature review shows that autogenous healing of concrete is a function of carbon dioxide availability, chloride, water wetting cycles, and carbonation content of water.

- Autogenous healing of concrete has also been shown to be a function of the local hydraulic gradient (Edvardson 1999). Under a hydraulic gradient of $15 \mathrm{~m} / \mathrm{m}$, a permissible crack width for autogenous healing ranges from 0.2 to $0.25 \mathrm{~mm}$ ( 0.008 to 0.01 in.) (see Table 2 Edvardson 1999).

- The results of Edvardson are consistent with the American Water Works Association Standard C301-99 for pre-stressed concrete pipes, where "over non-pressurized zones of pipe, exterior cracks in mortar coating up to 0.01 in $(0.25 \mathrm{~mm})$ are acceptable without repair."

- At the RH-LLW Disposal Facility, the chloride content of the water is in the non-aggressive range, water is close to saturated with respect to calcium, and the pore-environment should be minimally saturated, allowing the relative humidity to allow transport of carbon dioxide into the exterior concrete surfaces. Because of the drainage materials selected to be emplaced adjacent to and beneath the vault system, the local hydraulic gradient should be roughly $1 \mathrm{~mm} / 1 \mathrm{~mm}$ (i.e., unit gradient conditions). 
Therefore, given that the RH-LLW Disposal Facility subsurface environment has the potential to promote autogenous healing, a permissible crack width of 0.01 in. or less was applied for single cracks.

- Level 3 criteria. Crack widths exceeding 0.01 in. triggered a CAR. The presence of spider cracks, defined as three or more cracks $>0.005$-in. within a 2 -in. area, triggers a CAR because of the propensity to develop larger cracks (as stated in ACI 446.1R-91, "Fracture Mechanics of Concrete").

- Effect of Chipping, Spalling, and Other Damage to the Top Edges, Bottom Edges, Top Tongue, and Plug Edges. Physical damage, typically occurring during removal of components from the forms or while moving components, can result in chipped areas, spalled areas, and abrasion damage to the lift lug area. Criteria were established to identify limits with respect to the following:

- Level 1 criteria were defined to allow damage to edges of the upper riser section, base, and plug determined on the basis of not affecting shielding, structural, or environmental performance.

- Level 2 criteria were defined to allow repairable damage with the following considerations:

- Shielding: Impacts to environmental and shielding performance have been limited by specifying the depth of the repairable areas for the top edges and plugs.

The repair material used is of lower density than concrete components. The effect on shielding for repairable areas was evaluated in consideration of the lower concrete density and the Level 2 defined allowable physical damage in ECAR-2747 not affect bulk shielding of the components. The dose rate on top of the shield plug is limited to $1 \mathrm{mrem} / \mathrm{hour}$ and the maximum calculated value in ECAR-2747 is $0.5 \mathrm{mrem} /$ hour at the centerline of the shield plug, which is a factor of two below the limit. The proposed acceptable damage will not cause the dose rate limit to be exceeded.

In the gap analysis, the gap between adjacent shield plugs is filled with pea gravel. The dose rate above the gap filled with pea gravel is $0.1 \mathrm{mrem} /$ hour, which is a factor of 10 below the dose rate limit. The bulk shielding provided by the pea gravel is unaffected by minor damage to the various concrete components. Therefore, minor acceptable damage would have a negligible effect on the computed $0.1-\mathrm{mrem} /$ hour dose rate. The proposed acceptable damage without repair will not cause the dose rate limit to be exceeded.

- Structural Performance: The load bearing area with Level 2 repairable damage still allows vaults to meet design criteria during operations and with the final engineered cover, without the repairs having been performed. This allows not crediting the repaired area in the evaluation of structural performance impact.

- Environmental Performance (Long-Term Durability): Impacts to environmental performance have been limited by specifying the depth of the repairable areas for the top edge of all components. Repairs for Level 2 conditions will replace the lost concrete with a slightly less dense repair material, resulting in an insignificant decrease in concrete durability. The distance between the concrete surface and reinforcement materials is larger on the vault top edges, bottom edges, and tongue areas than it is in the vault walls. The defined allowable repair thickness maintains a concrete-to-reinforcement-cover thickness in excess of 2.5-in. (i.e., higher than in the undamaged vault wall). Therefore, repaired damage to these areas will still leave concrete cover thicknesses comparable to that in the vault walls.

$\circ$ Vault Fitment and Container Fit-Up: Each of the damaged areas was independently evaluated to ensure a failed repair would not impact vault operations and disposal of waste containers.

- Level 3 criteria. Spalling exceeding the Level 2 criteria triggered a CAR. 


\subsection{Concrete Repair Products}

Concrete repair materials were used to meet the primary criteria specified in SPC-1437 for the vault component compressive strength and environmental durability and are as follows:

- Have a minimum compressive strength of 5,000 psi at 28 days, matching the requirements for concrete used in vault components. The Jet Set Complete Repair product used for all repairs has a 28-day compressive strength in excess of 6,000 psi, which exceeds the 5,000-psi design compressive strength of the vault mix design (see Table 6).

- To ensure long-term environmental durability of repaired areas, the repair material was selected on the basis of being comprised of low alkali cement and sand to ensure the repair materials did not degrade radiolytically. Bonding agents (i.e., acrylic polymer admixtures) were allowed to be used for minor repairs to increase the initial strength of the repair bond. However, bonding agents were not allowed to be used as an internal component to the repair material. Therefore, the repairs were made using two components as follows:

- The Jet Set Complete Repair product used as the repair material is comprised of low alkali cement and sand (see Table 7).

- The bonding agent, MasterEmaco 600, was used to provide early strength bonding of the repair material to the vault component cement (see Table 8). Bonding agents are used either in the repair grout mix or applied to the surfaces being repaired. These bonding agents are typically acrylic-polymers that could degrade over time.

If the bonding agent had been mixed into the grout mix, the mixing proportions would have replaced roughly half the water added to the repair mix. As such, the relative water-cement ratio would be roughly the same as the vault cement mix. This material, applied as part of the grout, would be expected to remain in place during the vault transport and installation process and to remain in place through plug emplacement; however, it would be expected to degrade radiolytically after waste emplacement, resulting in a more porous and less dense repaired area. Instead, the bonding agent was just applied to the concrete surface prior to application of grout repair material. Therefore, it is expected that the repaired area will remain in place during vault transport, installation, and during plug and waste emplacement. After waste emplacement, it is expected the grout will remain in place and provide radiolytic protection for workers without degrading. Summary information for this product is given in Table 8.

Table 6. Performance characteristics for Jet Set Concrete Repair grout.

\begin{tabular}{llccl}
\hline $\begin{array}{c}\text { Performance } \\
\text { Metric }\end{array}$ & $\begin{array}{c}\text { Method of } \\
\text { Determination }\end{array}$ & Days & Metric & \multicolumn{1}{c}{ Comment } \\
\hline Compressive & ASTM C109 & 1 & 3,570 & Exceeds concrete compressive strength requirement of \\
strength (psi) & & 7 & 4,800 & 5,000 psi at 28 days. \\
& & 14 & 5,300 & \\
Flexural & ASTM C348 & 1 & 6,000 & \\
strength (psi) & & 7 & 570 & No requirement for this metric. \\
& & 28 & 1,330 & \\
Shrinkage \% & ASTM C596 & 7 & $0.087 \%$ & Very low shrinkage as required in SPC-1857. \\
Bond strength & ASTM C1042 & 1 & 574 & Not specified in SPC-1857. Bond strength is sufficient to \\
(psi) & & 3 & 850 & prevent repair fallout during normal handling operations. \\
& & 7 & 939 & \\
Tensile & ASTM C190 & 28 & 507 & Not specified in SPC-1857. \\
strength (psi) & & & & \\
Set times & ASTM C191 & Initial & 8 to 10 minutes & Quick setting, allowing repair, and removal to the yard. \\
& & final & 15 to 20 minutes & \\
\hline
\end{tabular}


Table 7. Composition information/ingredients for Jet Set Concrete Repair grout.

\begin{tabular}{|c|c|c|}
\hline Ingredient & Total Percentage & Comment \\
\hline Portland cement & 10 to $70 \%$ & This is one of the primary ingredients in the vault concrete. \\
\hline Silica sand & 30 to $50 \%$ & This is comparable to the aggregate used in the vault concrete. \\
\hline Calcium sulfate hemihydrate & 10 to $70 \%$ & $\begin{array}{l}\text { The natural form is gypsum (a mineral) and is formed during } \\
\text { hydration of cement. }\end{array}$ \\
\hline Calcium hydroxide & 10 to $70 \%$ & The natural form is lime, which is a component of cement. \\
\hline Magnesium hydroxide & 1 to $10 \%$ & $\begin{array}{l}\text { The natural form is the mineral brucite, which is a component of } \\
\text { cement. }\end{array}$ \\
\hline Silicon dioxide & 1 to $20 \%$ & $\begin{array}{l}\text { The natural form is quartz, which is a component of aggregate and } \\
\text { cement. }\end{array}$ \\
\hline Calcium aluminate & 10 to $70 \%$ & $\begin{array}{l}\text { A mineral formed by heating calcium oxide and aluminum oxide } \\
\text { and formed during hydration of cement. }\end{array}$ \\
\hline
\end{tabular}

Table 8. Performance metrics for the MasterEmaco A660 admixture with sand/cement mortar samples.

\begin{tabular}{llcc}
\hline \multicolumn{1}{c}{ Performance Metric } & $\begin{array}{c}\text { Method of } \\
\text { Determination }\end{array}$ & With Water & $\begin{array}{c}\text { With 1-to-1 MasterEmaco } \\
\text { A660 and Water }\end{array}$ \\
\hline $\begin{array}{l}\text { Compressive strength (psi) at } 28 \\
\text { days }\end{array}$ & ASTM C109 & 3,800 & 4,500 \\
Tensile strength (psi) at 28 days & ASTM C190 & 225 & 350 \\
Flexural strength (psi) at 28 days & ASTM C348 & 1,000 & 1,800 \\
\hline
\end{tabular}

\subsection{Concrete Defect and Damage Inspection Results}

During inspection of the three reinforced concrete vault components (bases, risers, and plugs) out of all 1542 individual vault components (excluding perimeter blocking), a total of 394 vault components were found to contain a fabrication defect or to be damaged as a result of handling the component. Compiled data for individual components are summarized in Table 9, with examples shown in Figures 4 through 9. Columns 1 and 2 contain the SNR number or the NCR number submitted to BEA for review and approval prior to addressing the reported defects and damage for the component listed in Column 3. These SNR and NCR reports contain the full description of the defects or damage for each component listed in Column 3. For spalling, the damage location is given in Column 4. Honeycombing typically occurred at the bottom edge of the form; therefore, it occurs on the component bottom or top depending on whether the components were poured with the forms inverted or right side up. The specific nonconforming Level 3 condition is listed in Column 5. Dimensions of the bounding (i.e., largest) Level 3 defect are given in Columns 6 through 9. Measurements of the dimensions are illustrated in Figures 4 through 9, with the length corresponding to the longest dimension, which is typically the horizontal dimension for damage occurring on a component top or bottom edge. The two widths for edge damage are provided to allow calculation of the affected component volume. The widths are measured perpendicular to the length. In the case of honeycombing or bugholes, the depth was reported as measured perpendicular to the concrete wall. In the case of spalling, the depth was reported as shown in Figure 4; therefore, it provides a conservative estimate of concrete remaining over the steel reinforcement. It also results in overestimating the concrete volume affected by the defect or damage. Column 10 contains the number of Level 3 damaged areas on each component. When the total area affected by Level 3 damage was computed, it was conservatively assumed that the area of each affected area was equal to the largest (worst case) area reported. Column 11 contains the total affected area computed as the sum of the rectangle areas: A $=$ length*(width $1+$ width 2$) *$ number of Level 3 damaged areas, and Column 12 contains the total volume computed as $\mathrm{V}=\mathrm{A} *$ depth. 
The summary of defects and damage by component type and vault array is provided in Table 10 . Vault component data are contained in Columns 2 through 4, beginning with the number of components (i.e., the number of upper riser sections) in the 55-ton array, LCC array, HFEF, NuPac, MFTC, and PA arrays in Column 2 followed by the total surface area and concrete volume in each component type in Columns 3 and 4 . The surface area for the upper vault riser section includes the inner and outer cylinder surface area and excludes the top and bottom tongue because they do not contribute significantly to the vault structural performance. Similarly, the surface area for the vault bases only includes the inner and outer cylinder surface area, while excluding the surface area contributed by the hexagonal base and tongue surface areas. The surface area of the plugs includes both the top and bottom surface area and six sides of the hexagonal plug. The total concrete volume was computed considering only the upper riser and base cylinder, conservatively neglecting the hexagonal base portion of the vault base and the concrete contained in the tongue mating surfaces for the risers and plugs.

Columns 5 through 7 of Table 9 contain the summary of defects for the specific vault array and component type. Column 5 provides the number of components with defects or damage. Column 6 contains the total defect or damaged area. Column 7 contains the volume of damaged concrete for each vault component type and each array type. The total impact on the array was assessed by computing the percentage relative to the vault array by component type. This information is provided in Columns 8 through 10. As shown in Column 8, the percentage of HFEF components exhibiting damage is relatively high compared to other vault components; however, the overall impact to surface area and volume is negligible.

Overall, the impact of this damage is superficial when quantified as a percentage of the total surface area within each array type and when quantified as a percentage of the overall concrete volume. There are no significant differences between the array types and no significant differences between component types within an array. Therefore, summary statistics support the assumption that defects/damage do not contribute to component failure in the overall concrete durability analysis. 
Table 9. Summary of Level 3 defect and damage inspection results for individual components.

\begin{tabular}{|c|c|c|c|c|c|c|c|c|c|c|c|}
\hline SNR & NCR & $\begin{array}{c}\text { Component } \\
\text { ID }^{\mathrm{a}}\end{array}$ & $\begin{array}{c}\text { Where } \\
\text { Damaged }\end{array}$ & $\begin{array}{c}\text { Nonconforming } \\
\text { Condition }\end{array}$ & $\begin{array}{l}\text { Length } \\
\text { (in) }\end{array}$ & $\begin{array}{c}\text { Width } \\
1 \\
\text { (in) } \\
\end{array}$ & $\begin{array}{c}\text { Width } \\
2 \\
\text { (in) } \\
\end{array}$ & $\begin{array}{l}\text { Depth } \\
\text { (in) }\end{array}$ & $\begin{array}{c}\text { Number of } \\
\text { Defects }\end{array}$ & $\begin{array}{c}\text { Defect } \\
\text { Area } \\
\left(\mathbf{i n}^{2}\right) \\
\end{array}$ & $\begin{array}{c}\text { Defect } \\
\text { Volume } \\
\left(\text { in }^{3}\right)\end{array}$ \\
\hline 65 & & $55 \mathrm{~T}-\mathrm{U} 1$ & & Bughole & 2.00 & 1.00 & 0.00 & 0.50 & 1 & 2.0 & 1.0 \\
\hline 47 & & $55 \mathrm{~T}-\mathrm{U} 2$ & Wall & Honeycombing & 24.60 & 2.50 & 0.00 & 0.25 & 1 & 61.5 & 15.4 \\
\hline 12 & & 55T-U7 & Wall & Bughole & 1.63 & 1.63 & 0.00 & 0.25 & 1 & 2.7 & 0.7 \\
\hline 75 & & 55T-U7 & & Honeycombing & 7.00 & 3.00 & 0.00 & 0.63 & 2 & 42.0 & 26.2 \\
\hline 47 & & 55T-U9 & Wall & Honeycombing & 22.00 & 1.00 & 0.00 & 0.38 & 1 & 22.0 & 8.3 \\
\hline 12 & & $55 \mathrm{~T}-\mathrm{U} 10$ & Wall & Bughole & 1.63 & 1.63 & 0.00 & 0.25 & 1 & 2.7 & 0.7 \\
\hline 47 & & 55T-U12 & Wall & Honeycombing & 6.00 & 1.50 & 0.00 & 0.38 & 1 & 9.0 & 3.4 \\
\hline 47 & & 55T-U13 & Wall & Honeycombing & 2.00 & 1.00 & 0.00 & 0.19 & 1 & 2.0 & 0.4 \\
\hline \multirow[t]{2}{*}{12} & & $55 \mathrm{~T}-\mathrm{U} 14$ & Wall & Bughole & 1.88 & 1.88 & 0.00 & 0.14 & 1 & 3.5 & 0.5 \\
\hline & 12 & 55T-U16 & Edge & Spalling & 4.50 & 2.50 & 0.50 & 0.50 & 1 & 13.5 & 6.8 \\
\hline 47 & & $55 \mathrm{~T}-\mathrm{U} 17$ & Wall & Honeycombing & 29.60 & 1.13 & 0.00 & 0.19 & 1 & 33.4 & 6.3 \\
\hline 54 & & 55T-U19 & & Honeycombing & 1.75 & 2.50 & 0.00 & 0.63 & 2 & 8.8 & 5.5 \\
\hline 46 & & $55 \mathrm{~T}-\mathrm{U} 21$ & Wall & Honeycombing & 4.88 & 0.38 & 0.00 & 0.13 & 1 & 1.8 & 0.2 \\
\hline \multirow[t]{2}{*}{53} & & 55T-U24 & Tongue & Spalling & 1.50 & 1.00 & 0.00 & 0.44 & 1 & 1.5 & 0.7 \\
\hline & 11 & $55 \mathrm{~T}-\mathrm{U} 25$ & Edge & Spalling & 3.00 & 1.25 & 0.88 & 0.50 & 1 & 6.4 & 3.2 \\
\hline 46 & & 55T-U28 & Wall & Bughole & 1.75 & 1.25 & 0.00 & 0.38 & 3 & 6.6 & 2.5 \\
\hline 47 & & 55T-U31 & Wall & Honeycombing & 9.00 & 3.50 & 0.00 & 0.25 & 1 & 31.5 & 7.9 \\
\hline \multirow[t]{3}{*}{46} & & $55 \mathrm{~T}-\mathrm{U} 32$ & Wall & Honeycombing & 2.00 & 0.75 & 0.00 & 0.13 & 1 & 1.5 & 0.2 \\
\hline & 12 & 55T-U33 & Edge & Spalling & 1.00 & 0.75 & 1.00 & 0.25 & 1 & 1.8 & 0.4 \\
\hline & 12 & $55 \mathrm{~T}-\mathrm{U} 33$ & Edge & Spalling & 1.19 & 1.00 & 0.19 & 0.31 & 1 & 1.4 & 0.4 \\
\hline 65 & & 55T-U40 & & Crack & 3.00 & 0.03 & 0.00 & 0.03 & 1 & 0.1 & 0.0 \\
\hline \multirow[t]{2}{*}{65} & & $55 \mathrm{~T}-\mathrm{U} 40$ & & Crack & 1.42 & 0.04 & 0.00 & 0.03 & 1 & 0.1 & 0.0 \\
\hline & 12 & 55T-U46 & Edge & Spalling & 3.50 & 4.50 & 1.00 & 1.00 & 1 & 19.2 & 19.2 \\
\hline 75 & & 55T-U48 & Edge & Spalling & 16.90 & 3.50 & 1.25 & 0.50 & 1 & 80.3 & 40.1 \\
\hline 72 & & 55T-U70 & Edge & Spalling & 5.00 & 3.00 & 0.75 & 0.75 & 1 & 18.8 & 14.1 \\
\hline 75 & & 55T-U77 & & Crack & 2.94 & 0.01 & 0.00 & 0.06 & 1 & 0.0 & 0.0 \\
\hline 93 & 25 & 55T-U82 & Edge & Spalling & 5.50 & 2.50 & 0.75 & 0.50 & 1 & 17.9 & 8.9 \\
\hline 118 & & 55T-U84 & Tongue & Spalling & 8.00 & 1.75 & 0.00 & 1.75 & 1 & 14.0 & 24.5 \\
\hline
\end{tabular}


Table 9. (continued).

\begin{tabular}{|c|c|c|c|c|c|c|c|c|c|c|c|}
\hline SNR & NCR & $\begin{array}{c}\text { Component } \\
\text { ID }^{\mathrm{a}} \\
\end{array}$ & $\begin{array}{c}\text { Where } \\
\text { Damaged }\end{array}$ & $\begin{array}{c}\text { Nonconforming } \\
\text { Condition }\end{array}$ & $\begin{array}{l}\text { Length } \\
\text { (in) }\end{array}$ & $\begin{array}{c}\text { Width } \\
\mathbf{1} \\
\text { (in) } \\
\end{array}$ & $\begin{array}{c}\text { Width } \\
2 \\
\text { (in) } \\
\end{array}$ & $\begin{array}{l}\text { Depth } \\
\text { (in) }\end{array}$ & $\begin{array}{c}\text { Number of } \\
\text { Defects }\end{array}$ & $\begin{array}{c}\text { Defect } \\
\text { Area } \\
\left(\text { in }^{2}\right) \\
\end{array}$ & $\begin{array}{c}\text { Defect } \\
\text { Volume } \\
\left(\text { in }^{3}\right)\end{array}$ \\
\hline 12 & & 55T-B1 & Wall & Bughole & 3.75 & 3.75 & 0.00 & 0.41 & 1 & 14.1 & 5.8 \\
\hline 46 & & 55T-B2 & Wall & Honeycombing & 5.00 & 1.50 & 0.00 & 0.19 & 1 & 7.5 & 1.4 \\
\hline 12 & & 55T-B3 & Wall & Bughole & 3.75 & 3.75 & 0.00 & 0.41 & 1 & 14.1 & 5.8 \\
\hline 12 & & 55T-B4 & Wall & Bughole & 3.75 & 3.75 & 0.00 & 0.41 & 1 & 14.1 & 5.8 \\
\hline 12 & & 55T-B5 & Wall & Bughole & 3.75 & 3.75 & 0.00 & 0.41 & 1 & 14.1 & 5.8 \\
\hline 12 & & 55T-B6 & Wall & Bughole & 2.13 & 2.13 & 0.00 & 0.33 & 1 & 4.5 & 1.5 \\
\hline 12 & & 55T-B7 & Wall & Bughole & 3.75 & 3.75 & 0.00 & 0.41 & 1 & 14.1 & 5.8 \\
\hline 12 & & 55T-B8 & Wall & Bughole & 3.75 & 3.75 & 0.00 & 0.41 & 1 & 14.1 & 5.8 \\
\hline 12 & & 55T-B9 & Wall & Bughole & 3.75 & 3.75 & 0.00 & 0.41 & 1 & 14.1 & 5.8 \\
\hline 46 & & 55T-B12 & Wall & Honeycombing & 5.19 & 1.25 & 0.00 & 0.25 & 5 & 32.4 & 8.1 \\
\hline 12 & & $55 \mathrm{~T}-\mathrm{B} 13$ & Wall & Bughole & 3.75 & 3.75 & 0.00 & 0.41 & 1 & 14.1 & 5.8 \\
\hline 12 & & 55T-B14 & Wall & Bughole & 3.75 & 3.75 & 0.00 & 0.41 & 1 & 14.1 & 5.8 \\
\hline 46 & & 55T-B14 & Wall & Honeycombing & 6.00 & 1.25 & 0.00 & 0.38 & 3 & 22.5 & 8.4 \\
\hline 47 & & 55T-B15 & Wall & Honeycombing & 5.00 & 1.00 & 0.00 & 0.50 & 1 & 5.0 & 2.5 \\
\hline 47 & & 55T-B15 & Wall & Bughole & 1.69 & 0.75 & 0.00 & 0.25 & 1 & 1.3 & 0.3 \\
\hline 65 & & 55T-B16 & & Bughole & 1.63 & 1.25 & 0.00 & 0.88 & 3 & 6.1 & 5.4 \\
\hline 48 & & 55T-B19 & Wall & Bughole & 2.13 & 0.75 & 0.00 & 0.25 & 33 & 52.7 & 13.2 \\
\hline 48 & & 55T-B19 & Edge & spalling & 4.00 & 1.50 & 0.00 & 0.50 & 1 & 6.0 & 3.0 \\
\hline 46 & & $55 \mathrm{~T}-\mathrm{B} 20$ & Wall & Bughole & 1.69 & 0.63 & 0.00 & 0.13 & 7 & 7.4 & 0.9 \\
\hline 46 & & $55 \mathrm{~T}-\mathrm{B} 20$ & Wall & Honeycombing & 8.00 & 1.25 & 0.00 & 0.50 & 2 & 20.0 & 10.0 \\
\hline 46 & & $55 \mathrm{~T}-\mathrm{B} 21$ & Wall & Honeycombing & 1.75 & 0.25 & 0.00 & 0.06 & 1 & 0.4 & 0.0 \\
\hline 48 & & 55T-B22 & Edge & spalling & 4.00 & 2.00 & 0.00 & 0.50 & 1 & 8.0 & 4.0 \\
\hline 48 & & $55 \mathrm{~T}-\mathrm{B} 22$ & Wall & Bughole & 2.19 & 0.63 & 0.00 & 0.13 & 1 & 1.4 & 0.2 \\
\hline 47 & & $55 \mathrm{~T}-\mathrm{B} 23$ & Wall & Bughole & 1.88 & 0.75 & 0.00 & 0.25 & 1 & 1.4 & 0.4 \\
\hline 46 & & 55T-B24 & Wall & Bughole & 2.38 & 0.88 & 0.00 & 0.13 & 13 & 27.1 & 3.4 \\
\hline 47 & & $55 \mathrm{~T}-\mathrm{B} 25$ & Wall & Bughole & 1.88 & 1.25 & 0.00 & 0.25 & 1 & 2.4 & 0.6 \\
\hline 46 & & $55 \mathrm{~T}-\mathrm{B} 26$ & Wall & Bughole & 1.63 & 1.13 & 0.00 & 0.06 & 6 & 11.1 & 0.7 \\
\hline 59 & & 55T-B27 & Tongue & Spalling & 6.00 & 2.00 & 0.00 & 0.50 & 1 & 12.0 & 6.0 \\
\hline
\end{tabular}


Table 9. (continued).

\begin{tabular}{|c|c|c|c|c|c|c|c|c|c|c|c|}
\hline SNR & NCR & $\begin{array}{c}\text { Component } \\
\text { ID }^{\mathbf{a}} \\
\end{array}$ & $\begin{array}{c}\text { Where } \\
\text { Damaged }\end{array}$ & $\begin{array}{c}\text { Nonconforming } \\
\text { Condition } \\
\end{array}$ & $\begin{array}{l}\text { Length } \\
\text { (in) }\end{array}$ & $\begin{array}{c}\text { Width } \\
\mathbf{1} \\
\text { (in) } \\
\end{array}$ & $\begin{array}{c}\text { Width } \\
2 \\
\text { (in) } \\
\end{array}$ & $\begin{array}{c}\text { Depth } \\
\text { (in) }\end{array}$ & $\begin{array}{c}\text { Number of } \\
\text { Defects }\end{array}$ & $\begin{array}{c}\text { Defect } \\
\text { Area } \\
\left(\text { in }^{2}\right) \\
\end{array}$ & $\begin{array}{c}\text { Defect } \\
\text { Volume } \\
\left(\text { in }^{3}\right)\end{array}$ \\
\hline 48 & & $55 \mathrm{~T}-\mathrm{B} 27$ & Wall & Honeycombing & 2.50 & 2.00 & 0.00 & 0.50 & 1 & 5.0 & 2.5 \\
\hline 46 & & 55T-B30 & Wall & Bughole & 2.00 & 1.25 & 0.00 & 0.06 & 1 & 2.5 & 0.2 \\
\hline 46 & & 55T-B31 & Wall & Honeycombing & 5.50 & 1.50 & 0.00 & 0.38 & 3 & 24.8 & 9.3 \\
\hline 46 & & 55T-B31 & Wall & Bughole & 2.00 & 2.00 & 0.00 & 0.25 & 5 & 20.0 & 5.0 \\
\hline \multirow[t]{2}{*}{46} & & 55T-B33 & Wall & Bughole & 1.75 & 1.00 & 0.00 & 0.38 & 3 & 5.3 & 2.0 \\
\hline & 14 & 55T-B53 & Edge & Spalling & 4.00 & 1.75 & 0.38 & 0.25 & 1 & 8.5 & 2.1 \\
\hline 91 & & 55T-B54 & Edge & spalling & 7.50 & 6.00 & 0.50 & 0.50 & 1 & 48.8 & 24.4 \\
\hline 75 & & 55T-B75 & Edge & Spalling & 5.75 & 2.00 & 1.25 & 0.25 & 1 & 18.7 & 4.7 \\
\hline 92 & 24 & 55T-B82 & Edge & Spalling & 8.50 & 3.50 & 1.00 & 1.00 & 1 & 38.2 & 38.2 \\
\hline 92 & 24 & 55T-B82 & Edge & Spalling & 5.00 & 2.00 & 0.75 & 0.75 & 1 & 13.8 & 10.3 \\
\hline 54 & & 55T-P2 & & Honeycombing & 1.88 & 1.25 & 0.00 & 0.38 & 1 & 2.4 & 0.9 \\
\hline 12 & & 55T-P5 & Wall & Bughole & 2.00 & 2.00 & 0.00 & 0.23 & 1 & 4.0 & 0.9 \\
\hline 12 & & 55T-P6 & Wall & Bughole & 2.00 & 2.00 & 0.00 & 0.23 & 1 & 4.0 & 0.9 \\
\hline 49 & & 55T-P7 & Edge & spalling & 3.00 & 1.75 & 0.50 & 0.50 & 1 & 6.8 & 3.4 \\
\hline 156 & & 55T-P7 & Corner & Spalling & 5.25 & 5.25 & 2.50 & 0.00 & 1 & 40.7 & 0.0 \\
\hline 65 & & 55T-P11 & Edge & Spalling & 54.00 & 1.50 & 0.50 & 0.50 & 1 & 108.0 & 54.0 \\
\hline 12 & & 55T-P12 & Wall & Bughole & 1.75 & 1.75 & 0.00 & 0.24 & 1 & 3.1 & 0.7 \\
\hline 49 & & $55 \mathrm{~T}-\mathrm{P} 23$ & Wall & Bughole & 1.75 & 1.00 & 0.00 & 0.38 & 1 & 1.8 & 0.7 \\
\hline 49 & & 55T-P25 & Wall & Honeycombing & 2.50 & 2.00 & 0.00 & 0.13 & 1 & 5.0 & 0.6 \\
\hline 156 & & 55T-P27 & Edge & Spalling & 4.00 & 2.75 & 0.63 & 0.50 & 1 & 13.5 & 6.8 \\
\hline 49 & & 55T-P28 & Edge & spalling & 3.00 & 3.25 & 0.00 & 0.13 & 1 & 9.8 & 1.2 \\
\hline 49 & & 55T-P31 & Edge & spalling & 2.50 & 4.50 & 0.00 & 0.13 & 2 & 22.5 & 2.8 \\
\hline 156 & & 55T-P32 & Edge & Spalling & 4.50 & 2.25 & 0.63 & 0.50 & 1 & 13.0 & 6.5 \\
\hline 156 & & 55T-P32 & Corner & Spalling & 2.50 & 2.50 & 2.50 & 0.00 & 1 & 12.5 & 0.0 \\
\hline 49 & & 55T-P33 & Wall & Bughole & 2.00 & 1.00 & 0.00 & 0.38 & 2 & 4.0 & 1.5 \\
\hline 49 & & 55T-P34 & Edge & spalling & 5.88 & 1.44 & 0.00 & 1.50 & 1 & 8.5 & 12.7 \\
\hline 156 & & 55T-P43 & Corner & Spalling & 4.00 & 4.50 & 2.00 & 0.00 & 1 & 26.0 & 0.0 \\
\hline 156 & & 55T-P44 & Corner & Spalling & 3.50 & 3.00 & 3.50 & 0.00 & 1 & 22.8 & 0.0 \\
\hline
\end{tabular}


Table 9. (continued).

\begin{tabular}{|c|c|c|c|c|c|c|c|c|c|c|c|}
\hline SNR & NCR & $\begin{array}{c}\text { Component } \\
\text { ID }^{\mathrm{a}} \\
\end{array}$ & $\begin{array}{c}\text { Where } \\
\text { Damaged }\end{array}$ & $\begin{array}{c}\text { Nonconforming } \\
\text { Condition } \\
\end{array}$ & $\begin{array}{l}\text { Length } \\
\text { (in) }\end{array}$ & $\begin{array}{c}\text { Width } \\
\mathbf{1} \\
\text { (in) } \\
\end{array}$ & $\begin{array}{c}\text { Width } \\
2 \\
\text { (in) } \\
\end{array}$ & $\begin{array}{c}\text { Depth } \\
\text { (in) }\end{array}$ & $\begin{array}{c}\text { Number of } \\
\text { Defects }\end{array}$ & $\begin{array}{c}\text { Defect } \\
\text { Area } \\
\left(\mathrm{in}^{2}\right) \\
\end{array}$ & $\begin{array}{c}\text { Defect } \\
\text { Volume } \\
\left(\text { in }^{3}\right)\end{array}$ \\
\hline 156 & & 55T-P47 & Edge & Spalling & 6.00 & 2.50 & 0.75 & 0.75 & 1 & 19.5 & 14.6 \\
\hline 82 & & 55T-P53 & Edge & Spalling & 9.13 & 6.00 & 0.75 & 0.25 & 1 & 61.6 & 15.4 \\
\hline 156 & & 55T-P53 & Edge & Spalling & 6.50 & 3.00 & 0.63 & 0.75 & 1 & 23.6 & 17.7 \\
\hline 156 & & 55T-P53 & Corner & Spalling & 6.00 & 1.75 & 6.00 & 0.00 & 1 & 46.5 & 0.0 \\
\hline 156 & & 55T-P62 & Corner & Spalling & 6.50 & 4.25 & 6.50 & 0.00 & 1 & 69.9 & 0.0 \\
\hline 114 & & 55T-P77 & Edge & Spalling & 5.25 & 0.75 & 2.75 & 0.50 & 1 & 18.4 & 9.2 \\
\hline 77 & & LC-U1 & & Crack & 86.00 & 0.02 & 0.00 & 0.03 & 1 & 1.6 & 0.0 \\
\hline & 19 & LC-U1B-2 & Edge & Spalling & 3.50 & 1.50 & 3.50 & 0.19 & 1 & 17.5 & 3.3 \\
\hline & 19 & LC-U1B-2 & Edge & Spalling & 2.50 & 0.50 & 3.00 & 0.38 & 1 & 8.8 & 3.3 \\
\hline 12 & & LC-U5 & Wall & Bughole & 1.63 & 1.63 & 0.00 & 0.25 & 1 & 2.7 & 0.7 \\
\hline 76 & & LC-U5 & & Honeycombing & 5.00 & 4.00 & 0.00 & 0.25 & 2 & 40.0 & 10.0 \\
\hline 57 & & LC-U6 & & Honeycombing & 53.30 & 3.50 & 0.00 & 0.50 & 3 & 560.0 & 280.0 \\
\hline 76 & & LC-U7 & & Honeycombing & 13.00 & 2.00 & 0.00 & 0.50 & 3 & 78.0 & 39.0 \\
\hline 12 & & LC-U8 & Wall & Bughole & 1.63 & 1.63 & 0.00 & 0.25 & 1 & 2.7 & 0.7 \\
\hline 57 & & LC-U11 & & Honeycombing & 16.90 & 2.63 & 0.00 & 0.50 & 11 & 489.0 & 244.0 \\
\hline 57 & & LC-U14 & & Honeycombing & 9.00 & 2.25 & 0.00 & 0.31 & 2 & 40.5 & 12.7 \\
\hline 57 & & LC-U15 & & Honeycombing & 96.40 & 4.00 & 0.00 & 0.50 & 6 & 2310.0 & 1160.0 \\
\hline 57 & & LC-U16 & & Honeycombing & 5.63 & 0.88 & 0.00 & 0.19 & 6 & 29.6 & 5.6 \\
\hline 57 & & LC-U17 & & Honeycombing & 13.00 & 0.38 & 0.00 & 0.31 & 2 & 9.8 & 3.1 \\
\hline 57 & & LC-U20 & & Honeycombing & 79.80 & 2.00 & 0.00 & 0.31 & 4 & 638.0 & 200.0 \\
\hline 57 & & LC-U21 & & Honeycombing & 9.50 & 3.50 & 0.00 & 0.31 & 1 & 33.2 & 10.4 \\
\hline 57 & & LC-U22 & & Honeycombing & 6.00 & 1.06 & 0.00 & 0.25 & 6 & 38.2 & 9.5 \\
\hline 57 & & LC-U28 & & Honeycombing & 6.50 & 2.50 & 0.00 & 0.06 & 4 & 65.0 & 4.1 \\
\hline 57 & & LC-U29 & & Honeycombing & 2.63 & 0.38 & 0.00 & 0.13 & 1 & 1.0 & 0.1 \\
\hline 57 & & LC-U34 & & Honeycombing & 4.00 & 3.00 & 0.00 & 0.06 & 1 & 12.0 & 0.8 \\
\hline 68 & & LC-U36 & & Honeycombing & 2.75 & 1.16 & 0.00 & 0.31 & 5 & 15.9 & 5.0 \\
\hline 76 & & LC-U39 & & Bughole & 3.75 & 0.50 & 0.00 & 0.13 & 2 & 3.8 & 0.5 \\
\hline 68 & & LC-U64 & Top Edge & Spalling & 3.25 & 1.25 & 0.00 & 1.00 & 1 & 4.1 & 4.1 \\
\hline
\end{tabular}


Table 9. (continued).

\begin{tabular}{|c|c|c|c|c|c|c|c|c|c|c|c|}
\hline SNR & NCR & $\begin{array}{c}\text { Component } \\
\text { ID }^{\mathbf{a}} \\
\end{array}$ & $\begin{array}{c}\text { Where } \\
\text { Damaged }\end{array}$ & $\begin{array}{c}\text { Nonconforming } \\
\text { Condition } \\
\end{array}$ & $\begin{array}{l}\text { Length } \\
\text { (in) }\end{array}$ & $\begin{array}{c}\text { Width } \\
1 \\
\text { (in) } \\
\end{array}$ & $\begin{array}{c}\text { Width } \\
2 \\
\text { (in) } \\
\end{array}$ & $\begin{array}{c}\text { Depth } \\
\text { (in) }\end{array}$ & $\begin{array}{c}\text { Number of } \\
\text { Defects }\end{array}$ & $\begin{array}{c}\text { Defect } \\
\text { Area } \\
\left(\text { in }^{2}\right) \\
\end{array}$ & $\begin{array}{c}\text { Defect } \\
\text { Volume } \\
\left(\text { in }^{3}\right)\end{array}$ \\
\hline & 13 & LC-U71-2 & Edge & Spalling & 0.75 & 0.75 & 0.75 & 0.25 & 1 & 1.1 & 0.3 \\
\hline & 13 & LC-U71-2 & Edge & Spalling & 4.00 & 2.50 & 3.50 & 0.50 & 1 & 24.0 & 12.0 \\
\hline & 13 & LC-U71-2 & Edge & Spalling & 3.00 & 1.38 & 2.50 & 0.50 & 1 & 11.6 & 5.8 \\
\hline & 13 & LC-U71-2 & Edge & Spalling & 2.25 & 1.63 & 2.25 & 0.50 & 1 & 8.7 & 4.4 \\
\hline & 13 & LC-U72-1 & Edge & Spalling & 8.00 & 3.63 & 5.75 & 0.88 & 1 & 75.0 & 65.7 \\
\hline 88 & & LC-U94 & Top Edge & Spalling & 17.00 & 3.25 & 0.00 & 1.13 & 1 & 55.2 & 62.4 \\
\hline 69 & & LC-U99-2 & Edge & Spalling & 12.00 & 4.00 & 0.00 & 0.75 & 1 & 48.0 & 36.0 \\
\hline 81 & & LC-U116 & Edge & spalling & 5.00 & 1.00 & 3.13 & 1.25 & 1 & 20.7 & 25.8 \\
\hline 137 & & LC-B1 & Liftlug & spalling & 1.00 & 1.00 & 0.00 & 0.63 & 1 & 1.0 & 0.6 \\
\hline 68 & & LC-B1 & Edge & Spalling & 3.00 & 2.00 & 0.00 & 1.50 & 1 & 6.0 & 9.0 \\
\hline 68 & & LC-B1B & & Bughole & 1.50 & 0.88 & 0.00 & 1.63 & 1 & 1.3 & 2.1 \\
\hline 137 & & LC-B1 & Base & Spalling & 1.00 & 1.00 & 0.00 & 0.63 & 1 & 1.0 & 0.6 \\
\hline 12 & & LC-B2 & Wall & Bughole & 3.75 & 3.75 & 0.00 & 0.41 & 1 & 14.1 & 5.8 \\
\hline 12 & & LC-B3 & Wall & Bughole & 3.75 & 3.75 & 0.00 & 0.41 & 1 & 14.1 & 5.8 \\
\hline 12 & & LC-B4 & Wall & Bughole & 3.75 & 3.75 & 0.00 & 0.41 & 1 & 14.1 & 5.8 \\
\hline 12 & & LC-B5 & Wall & Bughole & 3.75 & 3.75 & 0.00 & 0.41 & 1 & 14.1 & 5.8 \\
\hline 68 & & LC-B5 & & Honeycombing & 2.25 & 1.38 & 0.00 & 0.50 & 1 & 3.1 & 1.6 \\
\hline 12 & & LC-B7 & Wall & Bughole & 3.75 & 3.75 & 0.00 & 0.41 & 1 & 14.1 & 5.8 \\
\hline 76 & & LC-B9 & & Crack & 0.25 & 0.01 & 0.00 & 0.03 & 1 & 0.0 & 0.0 \\
\hline 12 & & LC-B9 & Wall & Bughole & 3.75 & 3.75 & 0.00 & 0.41 & 1 & 14.1 & 5.8 \\
\hline 12 & & LC-B10 & Wall & Bughole & 3.75 & 3.75 & 0.00 & 0.41 & 1 & 14.1 & 5.8 \\
\hline 68 & & 55T-B11 & & Bughole & 2.25 & 1.00 & 0.00 & 0.25 & 2 & 4.5 & 1.1 \\
\hline 68 & & 55T-B11 & & Honeycombing & 3.75 & 1.00 & 0.00 & 0.63 & 9 & 33.8 & 21.1 \\
\hline 12 & & LC-B11 & Wall & Bughole & 3.75 & 3.75 & 0.00 & 0.41 & 1 & 14.1 & 5.8 \\
\hline 12 & & LC-B12 & Wall & Bughole & 3.75 & 3.75 & 0.00 & 0.41 & 6 & 84.4 & 34.6 \\
\hline 12 & & LC-B13 & Wall & Bughole & 3.75 & 3.75 & 0.00 & 0.41 & 1 & 14.1 & 5.8 \\
\hline 12 & & LC-B14 & Wall & Bughole & 3.75 & 3.75 & 0.00 & 0.41 & 1 & 14.1 & 5.8 \\
\hline 57 & & LC-B16 & & Honeycombing & 2.00 & 1.88 & 0.00 & 0.44 & 1 & 3.8 & 1.7 \\
\hline
\end{tabular}


Table 9. (continued).

\begin{tabular}{|c|c|c|c|c|c|c|c|c|c|c|c|}
\hline SNR & NCR & $\begin{array}{c}\text { Component } \\
\text { ID }^{\mathbf{a}} \\
\end{array}$ & $\begin{array}{c}\text { Where } \\
\text { Damaged }\end{array}$ & $\begin{array}{c}\text { Nonconforming } \\
\text { Condition } \\
\end{array}$ & $\begin{array}{l}\text { Length } \\
\text { (in) }\end{array}$ & $\begin{array}{c}\text { Width } \\
\mathbf{1} \\
\text { (in) } \\
\end{array}$ & $\begin{array}{c}\text { Width } \\
2 \\
\text { (in) } \\
\end{array}$ & $\begin{array}{c}\text { Depth } \\
\text { (in) }\end{array}$ & $\begin{array}{c}\text { Number of } \\
\text { Defects }\end{array}$ & $\begin{array}{c}\text { Defect } \\
\text { Area } \\
\left(\mathrm{in}^{2}\right) \\
\end{array}$ & $\begin{array}{c}\text { Defect } \\
\text { Volume } \\
\left(\text { in }^{3}\right)\end{array}$ \\
\hline 68 & & LC-B17 & & Honeycombing & 3.00 & 2.00 & 0.00 & 0.88 & 1 & 6.0 & 5.3 \\
\hline 12 & & LC-B17 & Wall & Bughole & 3.75 & 3.75 & 0.00 & 0.41 & 1 & 14.1 & 5.8 \\
\hline 57 & & LC-B18 & & Honeycombing & 2.00 & 1.00 & 0.00 & 1.25 & 3 & 6.0 & 7.5 \\
\hline 57 & & LC-B18 & & Bughole & 2.25 & 3.00 & 0.00 & 0.50 & 1 & 6.8 & 3.4 \\
\hline 76 & & LC-B19 & & Bughole & 1.25 & 1.00 & 0.00 & 1.25 & 6 & 7.5 & 9.4 \\
\hline 76 & & LC-B20 & & Bughole & 1.75 & 1.25 & 0.00 & 1.13 & 6 & 13.1 & 14.8 \\
\hline 76 & & LC-B22 & Edge & Spalling & 3.00 & 2.00 & 0.00 & 2.00 & 1 & 6.0 & 12.0 \\
\hline 57 & & LC-B23 & & Honeycombing & 3.19 & 1.63 & 0.00 & 0.25 & 1 & 5.2 & 1.3 \\
\hline 68 & & LC-B24 & & Honeycombing & 8.50 & 2.50 & 0.00 & 0.25 & 1 & 21.2 & 5.3 \\
\hline 68 & & LC-B26 & & Honeycombing & 5.00 & 1.25 & 0.00 & 0.50 & 1 & 6.3 & 3.1 \\
\hline 88 & & LC-B27 & Top Edge & Spalling & 3.00 & 2.00 & 0.00 & 1.50 & 1 & 6.0 & 9.0 \\
\hline 68 & & LC-B28 & & Bughole & 1.50 & 1.38 & 0.00 & 1.50 & 8 & 16.6 & 24.8 \\
\hline 57 & & LC-B33 & & Bughole & 1.75 & 1.00 & 0.00 & 0.13 & 5 & 8.8 & 1.1 \\
\hline 57 & & LC-B34 & & Honeycombing & 3.00 & 2.00 & 0.00 & 0.13 & 1 & 6.0 & 0.8 \\
\hline 57 & & LC-B35 & & Bughole & 2.25 & 0.75 & 0.00 & 0.88 & 5 & 8.4 & 7.4 \\
\hline 68 & & LC-B36 & & Bughole & 1.50 & 1.06 & 0.00 & 0.13 & 2 & 3.2 & 0.4 \\
\hline 68 & & LC-B37 & & Bughole & 1.63 & 0.63 & 0.00 & 0.25 & 1 & 1.0 & 0.3 \\
\hline 57 & & LC-B38 & & Bughole & 1.75 & 0.04 & 0.00 & 0.38 & 3 & 0.2 & 0.1 \\
\hline 57 & & LC-B39 & & Honeycombing & 2.25 & 1.13 & 0.00 & 0.44 & 2 & 5.1 & 2.2 \\
\hline 68 & & 55T-B73 & Top Edge & Spalling & 6.00 & 2.50 & 0.00 & 1.00 & 1 & 15.0 & 15.0 \\
\hline 76 & & LC-B85 & Tongue & Spalling & 7.13 & 2.00 & 0.00 & 1.88 & 1 & 14.3 & 26.8 \\
\hline 68 & & LC-B87 & Top Edge & Spalling & 11.50 & 1.88 & 0.00 & 1.75 & 1 & 21.6 & 37.8 \\
\hline 76 & & LC-B87 & Tongue & Spalling & 11.50 & 1.88 & 0.00 & 1.75 & 1 & 21.6 & 37.8 \\
\hline 76 & & LC-B122 & & Crack & 3.63 & 0.02 & 0.00 & 0.03 & 1 & 0.1 & 0.0 \\
\hline 76 & & LC-B123 & & Crack & 0.75 & 0.02 & 0.00 & 0.03 & 1 & 0.0 & 0.0 \\
\hline 104 & & LC-B130 & Edge & Spalling & 15.00 & 0.75 & 6.00 & 0.75 & 1 & 101.0 & 75.9 \\
\hline 76 & & LC-B131 & Tongue & Spalling & 10.50 & 2.25 & 0.00 & 2.00 & 1 & 23.6 & 47.2 \\
\hline 76 & & LC-B131 & & Bughole & 1.13 & 1.75 & 0.00 & 1.13 & 1 & 2.0 & 2.2 \\
\hline
\end{tabular}


Table 9. (continued).

\begin{tabular}{|c|c|c|c|c|c|c|c|c|c|c|c|}
\hline SNR & NCR & $\begin{array}{c}\text { Component } \\
\text { ID }^{\mathbf{a}} \\
\end{array}$ & $\begin{array}{c}\text { Where } \\
\text { Damaged }\end{array}$ & $\begin{array}{c}\text { Nonconforming } \\
\text { Condition } \\
\end{array}$ & $\begin{array}{l}\text { Length } \\
\text { (in) }\end{array}$ & $\begin{array}{c}\text { Width } \\
1 \\
\text { (in) } \\
\end{array}$ & $\begin{array}{c}\text { Width } \\
2 \\
\text { (in) } \\
\end{array}$ & $\begin{array}{c}\text { Depth } \\
\text { (in) }\end{array}$ & $\begin{array}{c}\text { Number of } \\
\text { Defects }\end{array}$ & $\begin{array}{c}\text { Defect } \\
\text { Area } \\
\left(\text { in }^{2}\right) \\
\end{array}$ & $\begin{array}{c}\text { Defect } \\
\text { Volume } \\
\left(\text { in }^{3}\right)\end{array}$ \\
\hline 76 & & LC-B134 & Edge & Spalling & 9.25 & 3.38 & 1.50 & 1.00 & 1 & 45.1 & 45.1 \\
\hline & 37 & LC-B146 & Liftlug & & 9.13 & 8.25 & 0.00 & 1.00 & 1 & 75.3 & 75.3 \\
\hline 137 & & LC-B152 & Base & Spalling & 1.00 & 1.00 & 0.00 & 0.31 & 1 & 1.0 & 0.3 \\
\hline 137 & & LC-B152 & Liftlug & spalling & 1.00 & 1.00 & 0.00 & 0.31 & 1 & 1.0 & 0.3 \\
\hline & 41 & LC-B160 & Base & spalling & 3.00 & 3.00 & 0.00 & 0.50 & 1 & 9.0 & 4.5 \\
\hline & 41 & LC-B166 & Base & spalling & 5.00 & 5.00 & 0.00 & 0.81 & 1 & 25.0 & 20.3 \\
\hline & 41 & LC-B173 & Base & spalling & 4.75 & 4.75 & 0.00 & 1.00 & 1 & 22.6 & 22.6 \\
\hline & 41 & LC-B173 & Base & spalling & 4.75 & 4.75 & 0.00 & 0.50 & 1 & 22.6 & 11.3 \\
\hline & 41 & LC-B179 & Base & spalling & 3.00 & 3.00 & 0.00 & 0.31 & 1 & 9.0 & 2.8 \\
\hline 101 & & LC-B180 & Top Edge & Spalling & 4.00 & 3.00 & 1.75 & 1.00 & 1 & 19.0 & 19.0 \\
\hline & 41 & LC-B182 & Base & spalling & 5.00 & 5.00 & 0.00 & 0.88 & 1 & 25.0 & 21.9 \\
\hline & 41 & LC-B183 & Base & spalling & 3.50 & 3.50 & 0.00 & 0.38 & 1 & 12.2 & 4.6 \\
\hline & 41 & LC-B184 & Base & spalling & 4.75 & 4.75 & 0.00 & 0.63 & 1 & 22.6 & 14.1 \\
\hline & 41 & LC-B185 & Base & spalling & 6.00 & 6.00 & 0.00 & 0.75 & 1 & 36.0 & 27.0 \\
\hline & 41 & LC-B188 & Base & spalling & 4.00 & 4.00 & 0.00 & 0.56 & 1 & 16.0 & 9.0 \\
\hline & 34 & LC-B192 & Wall & Spalling & 6.00 & 5.00 & 0.00 & 0.25 & 1 & 30.0 & 7.5 \\
\hline & 41 & LC-B193 & Base & spalling & 5.00 & 5.00 & 0.00 & 0.50 & 1 & 25.0 & 12.5 \\
\hline 82 & & LC-P1A & Edge & Spalling & 3.50 & 2.50 & 0.94 & 0.88 & 1 & 12.0 & 10.5 \\
\hline 82 & & LC-P1 & Edge & Spalling & 1.50 & 1.50 & 1.00 & 0.50 & 1 & 3.8 & 1.9 \\
\hline 108 & & LC-P2 & Edge & Spalling & 2.75 & 2.25 & 1.88 & 0.63 & 3 & 34.1 & 21.3 \\
\hline 159 & & LC-P3 & Edge & Spalling & 10.00 & 7.50 & 1.50 & 1.25 & 1 & 90.0 & 112.0 \\
\hline 12 & & LC-P7 & Wall & Bughole & 2.00 & 2.00 & 0.00 & 0.23 & 1 & 4.0 & 0.9 \\
\hline 159 & & LC-P7 & Corner & Spalling & 4.25 & 3.75 & 3.75 & 0.00 & 1 & 31.9 & 0.0 \\
\hline 12 & & LC-P10 & Wall & Bughole & 2.00 & 2.00 & 0.00 & 0.23 & 1 & 4.0 & 0.9 \\
\hline 82 & & LC-P10 & Edge & Spalling & 2.00 & 2.25 & 1.88 & 0.50 & 1 & 8.3 & 4.1 \\
\hline 157 & & LC-P11 & Corner & Spalling & 3.00 & 4.75 & 3.00 & 0.00 & 1 & 23.2 & 0.0 \\
\hline 12 & & LC-P16 & Wall & Bughole & 2.00 & 2.00 & 0.00 & 0.23 & 1 & 4.0 & 0.9 \\
\hline 82 & & LC-P20 & Edge & Spalling & 3.50 & 1.13 & 1.88 & 0.63 & 1 & 10.5 & 6.6 \\
\hline
\end{tabular}


Table 9. (continued).

\begin{tabular}{|c|c|c|c|c|c|c|c|c|c|c|c|}
\hline SNR & NCR & $\begin{array}{c}\text { Component } \\
\text { ID }^{\mathbf{a}} \\
\end{array}$ & $\begin{array}{c}\text { Where } \\
\text { Damaged }\end{array}$ & $\begin{array}{c}\text { Nonconforming } \\
\text { Condition } \\
\end{array}$ & $\begin{array}{l}\text { Length } \\
\text { (in) }\end{array}$ & $\begin{array}{c}\text { Width } \\
1 \\
\text { (in) } \\
\end{array}$ & $\begin{array}{c}\text { Width } \\
2 \\
\text { (in) } \\
\end{array}$ & $\begin{array}{c}\text { Depth } \\
\text { (in) }\end{array}$ & $\begin{array}{c}\text { Number of } \\
\text { Defects }\end{array}$ & $\begin{array}{c}\text { Defect } \\
\text { Area } \\
\left(\text { in }^{2}\right) \\
\end{array}$ & $\begin{array}{c}\text { Defect } \\
\text { Volume } \\
\left(\text { in }^{3}\right)\end{array}$ \\
\hline & 23 & LC-P21 & Wall & Crack & 1.50 & 0.00 & 0.00 & 0.00 & 2 & 0.0 & 0.0 \\
\hline & 23 & LC-P23 & Wall & Crack & 9.00 & 0.01 & 0.00 & 0.00 & 1 & 0.1 & 0.0 \\
\hline 108 & & LC-P29 & Edge & Spalling & 5.25 & 1.25 & 2.00 & 0.88 & 1 & 17.1 & 14.9 \\
\hline 82 & & LC-P31 & & Honeycombing & 3.00 & 1.00 & 1.06 & 0.06 & 1 & 6.2 & 0.4 \\
\hline 82 & & LC-P59 & Edge & Spalling & 2.50 & 2.00 & 1.50 & 0.13 & 2 & 17.5 & 2.3 \\
\hline & 29 & LC-P65-2 & & Crack & 8.00 & 0.01 & 0.00 & 0.00 & 1 & 0.1 & 0.0 \\
\hline 82 & & LC-P71 & Edge & Spalling & 3.13 & 2.50 & 1.88 & 1.00 & 1 & 13.7 & 13.7 \\
\hline 82 & & LC-P82 & Edge & Spalling & 5.63 & 1.75 & 1.00 & 0.88 & 1 & 15.5 & 13.5 \\
\hline 82 & & LC-P95 & & Crack & 1.75 & 0.02 & 0.00 & 0.03 & 0 & 0.0 & 0.0 \\
\hline 124 & & LC-P95 & Wall & Crack Depth & 1.00 & 1.00 & 1.00 & 0.50 & 3 & 6.0 & 3.0 \\
\hline 124 & & LC-P95 & Wall & Crack & 47.00 & 0.02 & 0.00 & 0.00 & 1 & 1.0 & 0.0 \\
\hline 108 & & LC-P96 & Edge & Spalling & 4.13 & 3.50 & 1.13 & 0.25 & 5 & 95.6 & 23.9 \\
\hline & 29 & LC-P101 & & Crack & 3.00 & 0.01 & 0.00 & 0.00 & 1 & 0.0 & 0.0 \\
\hline & 29 & LC-P105 & Edge & Spalling & 9.50 & 4.00 & 1.00 & 0.75 & 1 & 47.5 & 35.6 \\
\hline & 22 & LC-P105- & Edge & Spalling & 9.50 & 4.00 & 1.00 & 0.75 & 1 & 47.5 & 35.6 \\
\hline 108 & & LC-P107 & Edge & Spalling & 12.50 & 5.63 & 3.00 & 1.38 & 3 & 324.0 & 447.0 \\
\hline & 29 & LC-P112 & Edge & Spalling & 7.25 & 4.50 & 1.25 & 1.50 & 1 & 41.7 & 62.5 \\
\hline 157 & & LC-P141 & Corner & Spalling & 5.25 & 3.00 & 5.25 & 0.00 & 1 & 43.3 & 0.0 \\
\hline 157 & & LC-P153 & Corner & Spalling & 9.00 & 5.75 & 9.00 & 0.00 & 1 & 133.0 & 0.0 \\
\hline 154 & & LC-P155 & Edge & Spalling & 6.75 & 3.63 & 1.13 & 0.88 & 1 & 32.1 & 28.3 \\
\hline 108 & & LC-P163 & Edge & Spalling & 6.00 & 5.13 & 1.13 & 1.00 & 1 & 37.6 & 37.6 \\
\hline & 24 & LC-P164 & Edge & Spalling & 13.00 & 8.00 & 2.00 & 2.00 & 1 & 130.0 & 260.0 \\
\hline 157 & & LC-P183 & Edge & Spalling & 26.00 & 3.50 & 1.25 & 0.88 & 1 & 124.0 & 109.0 \\
\hline 154 & & LC-P188 & Corner & Spalling & 8.00 & 7.25 & 7.25 & 0.00 & 1 & 116.0 & 0.0 \\
\hline 54 & & HFEF-U1 & & Honeycombing & 1.88 & 0.38 & 0.00 & 0.38 & 1 & 0.7 & 0.3 \\
\hline 56 & & HFEF-U3 & Wall & Crack & 2.00 & 0.03 & 0.00 & 0.03 & 1 & 0.1 & 0.0 \\
\hline 56 & & HFEF-U3 & & Crack & 2.00 & 0.03 & 0.00 & 0.03 & 1 & 0.1 & 0.0 \\
\hline 56 & & HFEF-U3 & & Honeycombing & 5.25 & 2.00 & 0.00 & 0.75 & 4 & 42.0 & 31.5 \\
\hline
\end{tabular}


Table 9. (continued).

\begin{tabular}{|c|c|c|c|c|c|c|c|c|c|c|c|}
\hline SNR & NCR & $\begin{array}{c}\text { Component } \\
\text { ID }^{\mathbf{a}} \\
\end{array}$ & $\begin{array}{c}\text { Where } \\
\text { Damaged }\end{array}$ & $\begin{array}{c}\text { Nonconforming } \\
\text { Condition } \\
\end{array}$ & $\begin{array}{l}\text { Length } \\
\text { (in) }\end{array}$ & $\begin{array}{c}\text { Width } \\
1 \\
\text { (in) } \\
\end{array}$ & $\begin{array}{c}\text { Width } \\
2 \\
\text { (in) } \\
\end{array}$ & $\begin{array}{c}\text { Depth } \\
\text { (in) }\end{array}$ & $\begin{array}{c}\text { Number of } \\
\text { Defects }\end{array}$ & $\begin{array}{c}\text { Defect } \\
\text { Area } \\
\left(\text { in }^{2}\right) \\
\end{array}$ & $\begin{array}{c}\text { Defect } \\
\text { Volume } \\
\left(\text { in }^{3}\right)\end{array}$ \\
\hline 56 & & HFEF-U3 & Wall & Honeycombing & 5.25 & 2.00 & 0.00 & 0.75 & 1 & 10.5 & 7.9 \\
\hline 56 & & HFEF-U4 & & Honeycombing & 2.75 & 1.88 & 0.00 & 0.63 & 5 & 25.9 & 16.2 \\
\hline 56 & & HFEF-U4 & & Crack & 3.50 & 0.01 & 0.00 & 0.03 & 1 & 0.0 & 0.0 \\
\hline 56 & & HFEF-U4 & Wall & Crack & 3.50 & 0.01 & 0.00 & 0.03 & 1 & 0.0 & 0.0 \\
\hline 56 & & HFEF-U4 & Wall & Honeycombing & 2.75 & 1.88 & 0.00 & 0.63 & 1 & 5.2 & 3.2 \\
\hline 56 & & HFEF-U5 & & Honeycombing & 10.50 & 2.50 & 0.00 & 1.25 & 4 & 105.0 & 131.0 \\
\hline 56 & & HFEF-U5 & Edge & Spalling & 35.00 & 1.25 & 0.00 & 0.25 & 1 & 43.8 & 10.9 \\
\hline 56 & & HFEF-U5 & Wall & Crack & 12.00 & 0.03 & 0.00 & 0.03 & 1 & 0.4 & 0.0 \\
\hline 56 & & HFEF-U5 & & Crack & 12.00 & 0.03 & 0.00 & 0.03 & 1 & 0.4 & 0.0 \\
\hline 56 & & HFEF-U5 & Edge & Spalling & 35.00 & 1.25 & 0.00 & 0.25 & 1 & 43.8 & 10.9 \\
\hline 56 & & HFEF-U5 & Wall & Honeycombing & 10.50 & 2.50 & 0.00 & 1.25 & 1 & 26.2 & 32.8 \\
\hline 54 & & HFEF-U6 & & Honeycombing & 3.88 & 1.00 & 0.00 & 0.13 & 6 & 23.3 & 2.9 \\
\hline 54 & & HFEF-U7 & & Honeycombing & 3.13 & 1.19 & 0.00 & 0.13 & 1 & 3.7 & 0.5 \\
\hline 56 & & HFEF-U8 & Wall & Honeycombing & 48.00 & 4.00 & 0.00 & 0.50 & 1 & 192.0 & 96.0 \\
\hline 154 & & HFEF-U8 & Edge & Spalling & 14.50 & 7.00 & 1.75 & 1.75 & 1 & 127.0 & 222.0 \\
\hline 56 & & HFEF-U8 & & Honeycombing & 48.00 & 4.00 & 0.00 & 0.50 & 4 & 768.0 & 384.0 \\
\hline 56 & & HFEF-U8 & & Crack & 1.75 & 0.02 & 0.00 & 0.03 & 1 & 0.0 & 0.0 \\
\hline 56 & & HFEF-U8 & Wall & Crack & 1.75 & 0.02 & 0.00 & 0.03 & 1 & 0.0 & 0.0 \\
\hline 56 & & HFEF-U10 & Wall & Bughole & 1.75 & 1.00 & 0.00 & 0.50 & 1 & 1.8 & 0.9 \\
\hline 56 & & HFEF-U10 & Wall & Honeycombing & 10.00 & 2.50 & 0.00 & 0.50 & 1 & 25.0 & 12.5 \\
\hline 56 & & HFEF-U10 & & Honeycombing & 10.00 & 2.50 & 0.00 & 0.13 & 7 & 175.0 & 21.9 \\
\hline 56 & & HFEF-U10 & & Crack & 5.00 & 0.01 & 0.00 & 0.03 & 1 & 0.1 & 0.0 \\
\hline 56 & & HFEF-U10 & & Bughole & 1.75 & 1.00 & 0.00 & 0.50 & 3 & 5.3 & 2.6 \\
\hline 56 & & HFEF-U10 & Wall & Crack & 5.00 & 0.01 & 0.00 & 0.03 & 1 & 0.1 & 0.0 \\
\hline 56 & & HFEF-U11 & Wall & Crack & 3.00 & 0.01 & 0.00 & 0.03 & 1 & 0.0 & 0.0 \\
\hline 56 & & HFEF-U11 & & Crack & 3.00 & 0.01 & 0.00 & 0.03 & 1 & 0.0 & 0.0 \\
\hline 62 & 8 & HFEF-U12 & Edge & spalling & 3.00 & 2.50 & 1.00 & 1.00 & 1 & 10.5 & 10.5 \\
\hline 54 & & HFEF-U12 & & Honeycombing & 3.00 & 2.00 & 0.00 & 0.06 & 1 & 6.0 & 0.4 \\
\hline
\end{tabular}


Table 9. (continued).

\begin{tabular}{|c|c|c|c|c|c|c|c|c|c|c|c|}
\hline SNR & NCR & $\begin{array}{c}\text { Component } \\
\text { ID }^{\mathbf{a}} \\
\end{array}$ & $\begin{array}{c}\text { Where } \\
\text { Damaged }\end{array}$ & $\begin{array}{c}\text { Nonconforming } \\
\text { Condition } \\
\end{array}$ & $\begin{array}{l}\text { Length } \\
\text { (in) }\end{array}$ & $\begin{array}{c}\text { Width } \\
1 \\
\text { (in) } \\
\end{array}$ & $\begin{array}{c}\text { Width } \\
2 \\
\text { (in) } \\
\end{array}$ & $\begin{array}{c}\text { Depth } \\
\text { (in) }\end{array}$ & $\begin{array}{c}\text { Number of } \\
\text { Defects }\end{array}$ & $\begin{array}{c}\text { Defect } \\
\text { Area } \\
\left(\text { in }^{2}\right) \\
\end{array}$ & $\begin{array}{c}\text { Defect } \\
\text { Volume } \\
\left(\text { in }^{3}\right)\end{array}$ \\
\hline 55 & & HFEF-U13 & & Bughole & 3.00 & 2.00 & 0.00 & 0.06 & 3 & 18.0 & 1.1 \\
\hline 55 & & HFEF-U13 & & Honeycombing & 2.50 & 1.00 & 0.00 & 0.25 & 1 & 2.5 & 0.6 \\
\hline 55 & & HFEF-U13 & Edge & Spalling & 3.00 & 1.00 & 0.00 & 0.25 & 1 & 3.0 & 0.8 \\
\hline 55 & & HFEF-U15 & Edge & Spalling & 12.00 & 4.50 & 0.00 & 1.75 & 1 & 54.0 & 94.5 \\
\hline 55 & & HFEF-U15 & & Honeycombing & 2.00 & 2.50 & 0.00 & 0.50 & 4 & 20.0 & 10.0 \\
\hline 56 & & HFEF-U16 & Wall & Crack & 8.50 & 0.02 & 0.00 & 0.03 & 1 & 0.2 & 0.0 \\
\hline 56 & & HFEF-U16 & Edge & Spalling & 8.00 & 1.13 & 0.00 & 0.50 & 1 & 9.0 & 4.5 \\
\hline 56 & & HFEF-U16 & Wall & Honeycombing & 6.00 & 2.75 & 0.00 & 0.63 & 1 & 16.5 & 10.3 \\
\hline 55 & & HFEF-BPT & & Honeycombing & 4.56 & 2.25 & 0.00 & 0.25 & 5 & 51.3 & 12.8 \\
\hline 55 & & HFEF-BPT & Edge & Spalling & 3.25 & 2.25 & 0.00 & 0.63 & 1 & 7.3 & 4.6 \\
\hline 54 & & HFEF-B1 & & Honeycombing & 13.10 & 2.94 & 0.00 & 0.38 & 9 & 347.0 & 130.0 \\
\hline 54 & & HFEF-B2 & & Honeycombing & 5.31 & 4.75 & 0.00 & 0.38 & 2 & 50.4 & 18.9 \\
\hline 55 & & HFEF-B4 & Edge & Spalling & 6.00 & 2.38 & 0.00 & 1.06 & 1 & 14.3 & 15.1 \\
\hline 54 & & HFEF-B5 & & Honeycombing & 5.00 & 3.13 & 0.00 & 0.38 & 5 & 78.2 & 29.3 \\
\hline 55 & & HFEF-B6 & Edge & Spalling & 4.88 & 1.88 & 0.00 & 1.13 & 1 & 9.2 & 10.4 \\
\hline 55 & & HFEF-B7 & Edge & Spalling & 5.75 & 2.75 & 0.00 & 1.13 & 1 & 15.8 & 17.9 \\
\hline 56 & & HFEF-B8 & Wall & Honeycombing & 3.25 & 0.75 & 0.00 & 0.25 & 1 & 2.4 & 0.6 \\
\hline 56 & & HFEF-B8 & & Honeycombing & 3.25 & 0.75 & 0.00 & 0.25 & 1 & 2.4 & 0.6 \\
\hline 54 & & HFEF-B10 & & Honeycombing & 2.00 & 1.25 & 0.00 & 0.63 & 6 & 15.0 & 9.4 \\
\hline 54 & & HFEF-B14 & & Bughole & 1.50 & 1.00 & 0.00 & 0.13 & 1 & 1.5 & 0.2 \\
\hline 54 & & HFEF-B15 & & Honeycombing & 6.00 & 1.00 & 0.00 & 0.06 & 4 & 24.0 & 1.5 \\
\hline & 999 & HFEF-P3 & Corner & Spalling & 4.00 & 4.50 & 4.00 & 0.00 & 1 & 34.0 & 0.0 \\
\hline 154 & & HFEF-P3 & Corner & Spalling & 9.63 & 5.00 & 3.00 & 0.00 & 1 & 77.0 & 0.0 \\
\hline 154 & & HFEF-P3 & Edge & Spalling & 24.00 & 2.00 & 4.88 & 1.50 & 1 & 165.0 & 248.0 \\
\hline 156 & & HFEF-P8 & Corner & Spalling & 3.25 & 3.00 & 3.25 & 0.00 & 1 & 20.3 & 0.0 \\
\hline 156 & & HFEF-P9 & Corner & Spalling & 3.25 & 2.75 & 3.25 & 0.00 & 1 & 19.5 & 0.0 \\
\hline 157 & & HFEF-P13 & Edge & Spalling & 6.25 & 2.50 & 1.38 & 1.25 & 1 & 24.2 & 30.3 \\
\hline 155 & & HFEF-P13 & Edge & Spalling & 24.00 & 1.00 & 2.50 & 0.75 & 1 & 84.0 & 63.0 \\
\hline
\end{tabular}


Table 9. (continued).

\begin{tabular}{|c|c|c|c|c|c|c|c|c|c|c|c|}
\hline SNR & NCR & $\begin{array}{c}\text { Component } \\
\text { ID }^{\mathbf{a}} \\
\end{array}$ & $\begin{array}{c}\text { Where } \\
\text { Damaged }\end{array}$ & $\begin{array}{c}\text { Nonconforming } \\
\text { Condition } \\
\end{array}$ & $\begin{array}{l}\text { Length } \\
\text { (in) }\end{array}$ & $\begin{array}{c}\text { Width } \\
1 \\
\text { (in) } \\
\end{array}$ & $\begin{array}{c}\text { Width } \\
2 \\
\text { (in) } \\
\end{array}$ & $\begin{array}{c}\text { Depth } \\
\text { (in) }\end{array}$ & $\begin{array}{c}\text { Number of } \\
\text { Defects }\end{array}$ & $\begin{array}{c}\text { Defect } \\
\text { Area } \\
\left(\text { in }^{2}\right) \\
\end{array}$ & $\begin{array}{c}\text { Defect } \\
\text { Volume } \\
\left(\text { in }^{3}\right)\end{array}$ \\
\hline 55 & & HFEF-P14 & Edge & Spalling & 2.00 & 1.75 & 0.00 & 0.50 & 1 & 3.5 & 1.8 \\
\hline 55 & & HFEF-P14 & & Honeycombing & 2.50 & 2.00 & 0.00 & 0.25 & 2 & 10.0 & 2.5 \\
\hline 155 & & HFEF-P15 & Corner & Spalling & 4.50 & 0.75 & 3.13 & 0.75 & 1 & 17.5 & 13.1 \\
\hline 155 & & HFEF-P15 & Corner & Spalling & 16.00 & 2.00 & 4.00 & 2.50 & 1 & 96.0 & 240.0 \\
\hline 155 & & HFEF-P15 & Corner & Spalling & 13.40 & 2.00 & 2.63 & 2.50 & 1 & 61.9 & 155.0 \\
\hline 155 & & HFEF-P15 & Corner & Spalling & 2.75 & 1.00 & 3.00 & 0.75 & 1 & 11.0 & 8.3 \\
\hline 42 & & NP-U1 & Wall & Crack & 1.00 & 0.03 & 0.00 & 0.03 & 1 & 0.0 & 0.0 \\
\hline 42 & & NP-U1 & Edge & Spalling & 2.00 & 1.00 & 0.00 & 0.63 & 1 & 2.0 & 1.3 \\
\hline 42 & & NP-U2 & Wall & Honeycombing & 3.00 & 1.00 & 0.00 & 0.63 & 1 & 3.0 & 1.9 \\
\hline 41 & & NP-U3 & Edge & Spalling & 4.00 & 1.00 & 0.00 & 0.50 & 1 & 4.0 & 2.0 \\
\hline 29 & & NP-U4 & Lift Lug & Crack & 2.00 & 0.03 & 0.00 & 0.00 & 5 & 0.3 & 0.0 \\
\hline 29 & & NP-U4 & Lift Lug & Crack & 2.00 & 0.03 & 0.00 & 0.00 & 5 & 0.3 & 0.0 \\
\hline \multirow[t]{2}{*}{12} & & NP-U5 & Wall & Bughole & 1.63 & 1.63 & 0.00 & 0.25 & 1 & 2.7 & 0.7 \\
\hline & 10 & NP-U5 & Edge & Spalling & 3.00 & 1.25 & 0.75 & 0.75 & 1 & 6.0 & 4.5 \\
\hline 29 & & NP-U7 & Lift Lug & Crack & 2.00 & 0.02 & 0.00 & 0.00 & 2 & 0.1 & 0.0 \\
\hline 29 & & NP-U7 & Lift Lug & Crack & 2.00 & 0.02 & 0.00 & 0.00 & 2 & 0.1 & 0.0 \\
\hline 42 & & NP-U9 & Edge & Spalling & 4.94 & 1.38 & 0.00 & 0.50 & 1 & 6.8 & 3.4 \\
\hline 42 & & NP-U9 & Wall & Honeycombing & 8.38 & 1.25 & 0.00 & 0.50 & 1 & 10.5 & 5.2 \\
\hline 43 & & NP-U14 & Wall & Bughole & 2.00 & 2.13 & 0.00 & 0.56 & 2 & 8.5 & 4.8 \\
\hline 31 & & NP-U17 & & Honeycombing & 3.38 & 1.00 & 0.00 & 0.25 & 4 & 13.5 & 3.4 \\
\hline 31 & & NP-U17 & Wall & Honeycombing & 3.38 & 1.00 & 0.00 & 0.25 & 4 & 13.5 & 3.4 \\
\hline 35 & & NP-U19 & & Honeycombing & 12.50 & 1.50 & 0.00 & 0.38 & 6 & 112.0 & 42.2 \\
\hline 45 & & NP-U19 & Wall & Crack Depth & 2.38 & 0.88 & 0.00 & 0.38 & 1 & 2.1 & 0.8 \\
\hline \multirow[t]{2}{*}{71} & 13 & NP-U19 & Edge & Spalling & 9.00 & 1.25 & 3.13 & 1.25 & 1 & 39.4 & 49.3 \\
\hline & 35 & NP-U19 & Wall & Honeycombing & 12.50 & 1.50 & 0.00 & 0.38 & 3 & 56.2 & 21.1 \\
\hline 45 & & NP-U19 & Wall & Crack & 48.00 & 0.02 & 0.00 & 0.03 & 1 & 0.9 & 0.0 \\
\hline 45 & & NP-U19 & Wall & Crack Depth & 2.38 & 0.88 & 0.00 & 0.38 & 1 & 2.1 & 0.8 \\
\hline 45 & & NP-U19 & Wall & Crack & 48.00 & 0.02 & 0.00 & 0.38 & 1 & 0.9 & 0.3 \\
\hline
\end{tabular}


Table 9. (continued).

\begin{tabular}{|c|c|c|c|c|c|c|c|c|c|c|c|}
\hline SNR & NCR & $\begin{array}{c}\text { Component } \\
\text { ID }^{\mathbf{a}} \\
\end{array}$ & $\begin{array}{c}\text { Where } \\
\text { Damaged }\end{array}$ & $\begin{array}{c}\text { Nonconforming } \\
\text { Condition } \\
\end{array}$ & $\begin{array}{l}\text { Length } \\
\text { (in) }\end{array}$ & $\begin{array}{c}\text { Width } \\
1 \\
\text { (in) } \\
\end{array}$ & $\begin{array}{c}\text { Width } \\
2 \\
\text { (in) } \\
\end{array}$ & $\begin{array}{c}\text { Depth } \\
\text { (in) }\end{array}$ & $\begin{array}{c}\text { Number of } \\
\text { Defects }\end{array}$ & $\begin{array}{c}\text { Defect } \\
\text { Area } \\
\left(\text { in }^{2}\right) \\
\end{array}$ & $\begin{array}{c}\text { Defect } \\
\text { Volume } \\
\left(\text { in }^{3}\right)\end{array}$ \\
\hline 35 & & NP-U19 & & Honeycombing & 12.50 & 1.50 & 0.00 & 0.38 & 6 & 112.0 & 42.2 \\
\hline \multirow[t]{2}{*}{12} & & NP-U20 & Wall & Bughole & 1.63 & 1.63 & 0.00 & 0.25 & 1 & 2.7 & 0.7 \\
\hline & 6 & NP-U21 & Edge & Spalling & 1.75 & 1.00 & 0.00 & 0.50 & 3 & 5.3 & 2.6 \\
\hline \multirow[t]{2}{*}{12} & & NP-U21 & Wall & Bughole & 1.63 & 1.63 & 0.00 & 0.25 & 1 & 2.7 & 0.7 \\
\hline & 6 & NP-U21 & Edge & Spalling & 1.75 & 1.00 & 0.00 & 0.50 & 3 & 5.3 & 2.6 \\
\hline 12 & & NP-U22 & Wall & Bughole & 1.63 & 1.63 & 0.00 & 0.25 & 1 & 2.7 & 0.7 \\
\hline 12 & & NP-U25 & Wall & Bughole & 1.63 & 1.63 & 0.00 & 0.25 & 1 & 2.7 & 0.7 \\
\hline 52 & & NP-U27 & Tongue & Spalling & 20.00 & 2.00 & 0.00 & 3.50 & 1 & 40.0 & 140.0 \\
\hline 31 & & NP-U27 & Wall & Honeycombing & 35.00 & 2.00 & 0.00 & 0.25 & 4 & 280.0 & 70.0 \\
\hline 31 & & NP-U27 & & Honeycombing & 35.00 & 2.00 & 0.00 & 0.25 & 4 & 280.0 & 70.0 \\
\hline \multirow[t]{3}{*}{45} & & NP-U29 & Wall & Spalling & 18.00 & 10.00 & 0.00 & 0.13 & 2 & 360.0 & 45.0 \\
\hline & 6 & NP-U30 & Edge & Spalling & 1.50 & 1.00 & 0.00 & 0.25 & 1 & 1.5 & 0.4 \\
\hline & 6 & NP-U30 & Edge & Spalling & 1.50 & 1.00 & 0.00 & 0.25 & 1 & 1.5 & 0.4 \\
\hline \multirow[t]{3}{*}{12} & & NP-U31 & Wall & Bughole & 1.63 & 1.63 & 0.00 & 0.25 & 1 & 2.7 & 0.7 \\
\hline & 6 & NP-U32 & Edge & Spalling & 2.00 & 1.00 & 0.00 & 0.38 & 1 & 2.0 & 0.8 \\
\hline & 6 & NP-U32 & Edge & Spalling & 2.00 & 1.00 & 0.00 & 0.38 & 1 & 2.0 & 0.8 \\
\hline \multirow[t]{2}{*}{12} & & NP-U33 & Wall & Bughole & 1.63 & 1.63 & 0.00 & 0.25 & 1 & 2.7 & 0.7 \\
\hline & 6 & NP-U39 & Edge & Spalling & 3.00 & 1.00 & 0.00 & 0.50 & 1 & 3.0 & 1.5 \\
\hline 31 & & NP-U39 & Wall & Honeycombing & 26.40 & 1.19 & 0.00 & 0.31 & 4 & 126.0 & 39.3 \\
\hline \multirow[t]{2}{*}{31} & & NP-U39 & & Honeycombing & 26.40 & 1.19 & 0.00 & 0.31 & 4 & 126.0 & 39.3 \\
\hline & 6 & NP-U39 & Edge & Spalling & 3.00 & 1.00 & 0.00 & 0.50 & 1 & 3.0 & 1.5 \\
\hline 31 & & NP-U40 & Wall & Honeycombing & 51.40 & 0.63 & 0.00 & 0.19 & 5 & 161.0 & 30.2 \\
\hline 31 & & NP-U40 & & Honeycombing & 51.40 & 0.63 & 0.00 & 0.19 & 5 & 161.0 & 30.2 \\
\hline 31 & & NP-U41 & Wall & Honeycombing & 10.90 & 0.38 & 0.00 & 0.19 & 3 & 12.3 & 2.3 \\
\hline 60 & & NP-U41 & Tongue & Spalling & 25.00 & 2.63 & 0.00 & 4.50 & 1 & 65.8 & 296.0 \\
\hline 60 & 1 & NP-U41 & Tongue & Spalling & 25.00 & 2.63 & 0.00 & 4.25 & 1 & 65.8 & 279.0 \\
\hline 31 & & NP-U41 & & Honeycombing & 10.90 & 0.38 & 0.00 & 0.19 & 3 & 12.3 & 2.3 \\
\hline 43 & & NP-U43 & Wall & Honeycombing & 1.88 & 1.25 & 0.00 & 0.63 & 2 & 4.7 & 2.9 \\
\hline
\end{tabular}


Table 9. (continued).

\begin{tabular}{|c|c|c|c|c|c|c|c|c|c|c|c|}
\hline SNR & NCR & $\begin{array}{c}\text { Component } \\
\text { ID }^{\mathrm{a}} \\
\end{array}$ & $\begin{array}{c}\text { Where } \\
\text { Damaged }\end{array}$ & $\begin{array}{c}\text { Nonconforming } \\
\text { Condition } \\
\end{array}$ & $\begin{array}{c}\text { Length } \\
\text { (in) }\end{array}$ & $\begin{array}{c}\text { Width } \\
1 \\
\text { (in) } \\
\end{array}$ & $\begin{array}{c}\text { Width } \\
2 \\
\text { (in) } \\
\end{array}$ & $\begin{array}{c}\text { Depth } \\
\text { (in) }\end{array}$ & $\begin{array}{c}\text { Number of } \\
\text { Defects }\end{array}$ & $\begin{array}{c}\text { Defect } \\
\text { Area } \\
\left(\text { in }^{2}\right) \\
\end{array}$ & $\begin{array}{c}\text { Defect } \\
\text { Volume } \\
\left(\text { in }^{3}\right)\end{array}$ \\
\hline \multirow[t]{4}{*}{43} & & NP-U43 & Edge & Spalling & 1.75 & 1.88 & 0.00 & 0.75 & 1 & 3.3 & 2.5 \\
\hline & 6 & NP-U46 & Edge & Spalling & 1.00 & 1.00 & 0.00 & 0.25 & 1 & 1.0 & 0.3 \\
\hline & 6 & NP-U46 & Edge & Spalling & 1.00 & 1.00 & 0.00 & 0.25 & 1 & 1.0 & 0.3 \\
\hline & 10 & NP-U49 & Edge & Spalling & 2.00 & 1.25 & 0.25 & 0.25 & 1 & 3.0 & 0.8 \\
\hline 31 & & NP-U50 & & Honeycombing & 4.00 & 2.00 & 0.00 & 0.25 & 2 & 16.0 & 4.0 \\
\hline 31 & & NP-U50 & Wall & Honeycombing & 4.00 & 2.00 & 0.00 & 0.25 & 2 & 16.0 & 4.0 \\
\hline 31 & & NP-U51 & & Bughole & 2.63 & 0.13 & 0.00 & 0.06 & 1 & 0.3 & 0.0 \\
\hline 31 & & NP-U51 & & Honeycombing & 4.13 & 0.38 & 0.00 & 0.13 & 2 & 3.1 & 0.4 \\
\hline 31 & & NP-U51 & Wall & Bughole & 2.63 & 0.13 & 0.00 & 0.06 & 1 & 0.3 & 0.0 \\
\hline 31 & & NP-U51 & Wall & Honeycombing & 4.13 & 0.38 & 0.00 & 0.13 & 2 & 3.1 & 0.4 \\
\hline 31 & & NP-U52 & & Bughole & 2.25 & 0.06 & 0.00 & 0.06 & 1 & 0.1 & 0.0 \\
\hline 31 & & NP-U52 & & Honeycombing & 10.00 & 3.50 & 0.00 & 0.13 & 3 & 105.0 & 13.1 \\
\hline 31 & & NP-U52 & Wall & Honeycombing & 10.00 & 3.50 & 0.00 & 0.13 & 7 & 245.0 & 30.6 \\
\hline 31 & & NP-U53 & Wall & Honeycombing & 3.00 & 0.88 & 0.00 & 0.06 & 2 & 5.3 & 0.3 \\
\hline 31 & & NP-U53 & & Honeycombing & 3.00 & 0.88 & 0.00 & 0.06 & 2 & 5.3 & 0.3 \\
\hline 31 & & NP-U54 & Wall & Honeycombing & 3.00 & 2.00 & 0.00 & 0.06 & 1 & 6.0 & 0.4 \\
\hline 31 & & NP-U54 & & Bughole & 2.50 & 0.25 & 0.00 & 0.06 & 1 & 0.6 & 0.0 \\
\hline 31 & & NP-U54 & & Honeycombing & 3.00 & 2.00 & 0.00 & 0.06 & 1 & 6.0 & 0.4 \\
\hline 31 & & NP-U54 & Wall & Bughole & 2.50 & 0.25 & 0.00 & 0.06 & 1 & 0.6 & 0.0 \\
\hline 31 & & NP-U55 & & Bughole & 2.06 & 1.00 & 0.00 & 0.25 & 6 & 12.4 & 3.1 \\
\hline \multirow[t]{2}{*}{31} & & NP-U55 & Wall & Bughole & 2.06 & 1.00 & 0.00 & 0.25 & 6 & 12.4 & 3.1 \\
\hline & 12 & NP-U55 & Edge & Spalling & 3.00 & 0.50 & 0.44 & 0.44 & 1 & 2.8 & 1.2 \\
\hline 112 & & NP-U55 & Tongue & Spalling & 7.00 & 2.00 & 1.75 & 0.75 & 1 & 26.2 & 19.7 \\
\hline 31 & & NP-U55 & Wall & Honeycombing & 4.00 & 1.50 & 0.00 & 0.06 & 4 & 24.0 & 1.5 \\
\hline 31 & & NP-U55 & & Honeycombing & 4.00 & 1.50 & 0.00 & 0.06 & 4 & 24.0 & 1.5 \\
\hline 35 & & NP-U56 & & Bughole & 3.00 & 0.25 & 0.00 & 0.06 & 1 & 0.8 & 0.0 \\
\hline \multirow[t]{2}{*}{35} & & NP-U56 & & Honeycombing & 20.00 & 2.00 & 0.00 & 0.25 & 3 & 120.0 & 30.0 \\
\hline & 35 & NP-U56 & Wall & Honeycombing & 20.00 & 2.00 & 0.00 & 0.25 & 2 & 80.0 & 20.0 \\
\hline
\end{tabular}


Table 9. (continued).

\begin{tabular}{|c|c|c|c|c|c|c|c|c|c|c|c|}
\hline SNR & NCR & $\begin{array}{c}\text { Component } \\
\text { ID }^{\mathrm{a}}\end{array}$ & $\begin{array}{c}\text { Where } \\
\text { Damaged }\end{array}$ & $\begin{array}{c}\text { Nonconforming } \\
\text { Condition } \\
\end{array}$ & $\begin{array}{l}\text { Length } \\
\text { (in) }\end{array}$ & $\begin{array}{c}\text { Width } \\
\mathbf{1} \\
\text { (in) } \\
\end{array}$ & $\begin{array}{c}\text { Width } \\
2 \\
\text { (in) } \\
\end{array}$ & $\begin{array}{c}\text { Depth } \\
\text { (in) }\end{array}$ & $\begin{array}{c}\text { Number of } \\
\text { Defects }\end{array}$ & $\begin{array}{c}\text { Defect } \\
\text { Area } \\
\left(\mathrm{in}^{2}\right) \\
\end{array}$ & $\begin{array}{c}\text { Defect } \\
\text { Volume } \\
\left(\text { in }^{3}\right)\end{array}$ \\
\hline & 35 & NP-U58 & Wall & Bughole & 2.00 & 0.50 & 0.00 & 0.25 & 3 & 3.0 & 0.8 \\
\hline 35 & & NP-U58 & & Bughole & 2.00 & 0.50 & 0.00 & 0.25 & 1 & 1.0 & 0.3 \\
\hline & 35 & NP-U58 & Wall & Honeycombing & 6.00 & 2.00 & 0.00 & 0.13 & 2 & 24.0 & 3.0 \\
\hline 35 & & NP-U58 & & Honeycombing & 6.00 & 2.00 & 0.00 & 0.13 & 1 & 12.0 & 1.5 \\
\hline 35 & & NP-U59 & & Honeycombing & 2.25 & 0.75 & 0.00 & 0.13 & 1 & 1.7 & 0.2 \\
\hline & 35 & NP-U59 & Wall & Honeycombing & 2.25 & 0.75 & 0.00 & 0.19 & 2 & 3.4 & 0.6 \\
\hline 55 & & NP-U60 & & Honeycombing & 2.50 & 0.69 & 0.00 & 0.25 & 3 & 5.2 & 1.3 \\
\hline 12 & & NP-B1 & Wall & Bughole & 3.75 & 3.75 & 0.00 & 0.41 & 1 & 14.1 & 5.8 \\
\hline 45 & & NP-B2 ${ }^{b}$ & Wall & Bughole & 2.25 & 1.00 & 0.00 & 0.25 & 3 & 6.8 & 1.7 \\
\hline 45 & & NP-B $2^{b}$ & Wall & Bughole & 2.25 & 1.00 & 0.00 & 0.25 & 2 & 4.5 & 1.1 \\
\hline 45 & & $\mathrm{NP}-\mathrm{B} 2^{\mathrm{b}}$ & Wall & Crack & 2.25 & 0.06 & 0.00 & 0.00 & 4 & 0.5 & 0.0 \\
\hline 45 & & NP-B2 ${ }^{b}$ & Wall & Crack & 2.25 & 0.06 & 0.00 & 0.00 & 4 & 0.5 & 0.0 \\
\hline 12 & & NP-B3 & Wall & Bughole & 3.75 & 3.75 & 0.00 & 0.41 & 1 & 14.1 & 5.8 \\
\hline 34 & & NP-B3 & Lift Lug & Crack & 2.00 & 0.02 & 0.00 & 0.00 & 3 & 0.1 & 0.0 \\
\hline 12 & & NP-B5 & Wall & Bughole & 3.75 & 3.75 & 0.00 & 0.41 & 1 & 14.1 & 5.8 \\
\hline 43 & & NP-B6 & Wall & Bughole & 1.75 & 0.50 & 0.00 & 0.25 & 1 & 0.9 & 0.2 \\
\hline 31 & & NP-B7 & Wall & Honeycombing & 6.00 & 1.50 & 0.00 & 0.38 & 2 & 18.0 & 6.8 \\
\hline 31 & & NP-B7 & & Honeycombing & 6.00 & 1.50 & 0.00 & 0.38 & 2 & 18.0 & 6.8 \\
\hline 29 & & NP-B7 & Lift Lug & Crack & 2.00 & 0.03 & 0.00 & 0.00 & 1 & 0.1 & 0.0 \\
\hline 29 & & NP-B7 & Lift Lug & Crack & 2.00 & 0.03 & 0.00 & 0.00 & 1 & 0.1 & 0.0 \\
\hline 29 & & NP-B8 & Lift Lug & Crack & 2.00 & 0.03 & 0.00 & 0.00 & 1 & 0.1 & 0.0 \\
\hline 29 & & NP-B8 & Lift Lug & Crack & 2.00 & 0.03 & 0.00 & 0.00 & 1 & 0.1 & 0.0 \\
\hline 12 & & NP-B9 & Wall & Bughole & 3.75 & 3.75 & 0.00 & 0.41 & 1 & 14.1 & 5.8 \\
\hline 29 & & NP-B9 & Lift Lug & Crack & 2.00 & 0.03 & 0.00 & 0.00 & 1 & 0.1 & 0.0 \\
\hline 29 & & NP-B9 & Lift Lug & Crack & 2.00 & 0.03 & 0.00 & 0.00 & 1 & 0.1 & 0.0 \\
\hline 12 & & NP-B10 & Wall & Bughole & 3.75 & 3.75 & 0.00 & 0.41 & 1 & 14.1 & 5.8 \\
\hline 43 & & NP-B12 & Edge & Spalling & 4.00 & 1.00 & 0.00 & 1.13 & 1 & 4.0 & 4.5 \\
\hline 12 & & NP-B14 & Wall & Bughole & 3.75 & 3.75 & 0.00 & 0.41 & 1 & 14.1 & 5.8 \\
\hline
\end{tabular}


Table 9. (continued).

\begin{tabular}{|c|c|c|c|c|c|c|c|c|c|c|c|}
\hline SNR & NCR & $\begin{array}{c}\text { Component } \\
\text { ID }^{\mathbf{a}} \\
\end{array}$ & $\begin{array}{c}\text { Where } \\
\text { Damaged }\end{array}$ & $\begin{array}{c}\text { Nonconforming } \\
\text { Condition } \\
\end{array}$ & $\begin{array}{l}\text { Length } \\
\text { (in) }\end{array}$ & $\begin{array}{c}\text { Width } \\
\mathbf{1} \\
\text { (in) } \\
\end{array}$ & $\begin{array}{c}\text { Width } \\
2 \\
\text { (in) } \\
\end{array}$ & $\begin{array}{c}\text { Depth } \\
\text { (in) }\end{array}$ & $\begin{array}{c}\text { Number of } \\
\text { Defects }\end{array}$ & $\begin{array}{c}\text { Defect } \\
\text { Area } \\
\left(\mathrm{in}^{2}\right) \\
\end{array}$ & $\begin{array}{c}\text { Defect } \\
\text { Volume } \\
\left(\text { in }^{3}\right)\end{array}$ \\
\hline 12 & & NP-B15 & Wall & Bughole & 3.75 & 3.75 & 0.00 & 0.41 & 1 & 14.1 & 5.8 \\
\hline 12 & & NP-B16 & Wall & Bughole & 3.75 & 3.75 & 0.00 & 0.41 & 1 & 14.1 & 5.8 \\
\hline 12 & & NP-B17 & Wall & Bughole & 3.75 & 3.75 & 0.00 & 0.41 & 1 & 14.1 & 5.8 \\
\hline 12 & & NP-B18 & Wall & Bughole & 3.75 & 3.75 & 0.00 & 0.41 & 1 & 14.1 & 5.8 \\
\hline 12 & & NP-B19 & Wall & Bughole & 3.75 & 3.75 & 0.00 & 0.41 & 1 & 14.1 & 5.8 \\
\hline 12 & & NP-B20 & Wall & Bughole & 3.75 & 3.75 & 0.00 & 0.41 & 1 & 14.1 & 5.8 \\
\hline 12 & & NP-B22 & Wall & Bughole & 3.75 & 3.75 & 0.00 & 0.41 & 1 & 14.1 & 5.8 \\
\hline 31 & & NP-B23 & Wall & Honeycombing & 3.00 & 1.00 & 0.00 & 0.06 & 1 & 3.0 & 0.2 \\
\hline 31 & & NP-B23 & Wall & Bughole & 2.25 & 1.13 & 0.00 & 0.06 & 5 & 12.7 & 0.8 \\
\hline 31 & & NP-B23 & & Bughole & 2.25 & 1.13 & 0.00 & 0.06 & 5 & 12.7 & 0.8 \\
\hline 31 & & NP-B23 & & Honeycombing & 3.00 & 1.00 & 0.00 & 0.06 & 1 & 3.0 & 0.2 \\
\hline 12 & & NP-B24 & Wall & Bughole & 3.75 & 3.75 & 0.00 & 0.41 & 1 & 14.1 & 5.8 \\
\hline 12 & & NP-B25 & Wall & Bughole & 3.75 & 3.75 & 0.00 & 0.41 & 1 & 14.1 & 5.8 \\
\hline 12 & & NP-B26 & Wall & Bughole & 3.75 & 3.75 & 0.00 & 0.41 & 1 & 14.1 & 5.8 \\
\hline 12 & & NP-B27 & Wall & Bughole & 3.75 & 3.75 & 0.00 & 0.41 & 1 & 14.1 & 5.8 \\
\hline 51 & & NP-B27 & Edge & Spalling & 10.00 & 2.50 & 0.50 & 0.50 & 1 & 30.0 & 15.0 \\
\hline 12 & & NP-B28 & Wall & Bughole & 3.75 & 3.75 & 0.00 & 0.41 & 1 & 14.1 & 5.8 \\
\hline & 9 & NP-B28 & Edge & Spalling & 3.00 & 1.25 & 0.50 & 0.50 & 1 & 5.3 & 2.6 \\
\hline 45 & & NP-B29 & Edge & Spalling & 18.00 & 10.00 & 0.00 & 0.13 & 3 & 540.0 & 67.5 \\
\hline 43 & & NP-B31 & Edge & Spalling & 2.00 & 1.00 & 0.00 & 0.06 & 1 & 2.0 & 0.1 \\
\hline 43 & & NP-B31 & Wall & Honeycombing & 12.00 & 1.00 & 0.00 & 1.25 & 2 & 24.0 & 30.0 \\
\hline 12 & & NP-B32 & Wall & Bughole & 3.75 & 3.75 & 0.00 & 0.41 & 1 & 14.1 & 5.8 \\
\hline 12 & & NP-B33 & Wall & Bughole & 3.75 & 3.75 & 0.00 & 0.41 & 1 & 14.1 & 5.8 \\
\hline 43 & & NP-B34 & Edge & Spalling & 10.90 & 13.00 & 0.00 & 0.13 & 1 & 142.0 & 17.7 \\
\hline 12 & & NP-B34 & Wall & Bughole & 3.75 & 3.75 & 0.00 & 0.41 & 1 & 14.1 & 5.8 \\
\hline 12 & & NP-B35 & Wall & Bughole & 3.75 & 3.75 & 0.00 & 0.41 & 1 & 14.1 & 5.8 \\
\hline 12 & & NP-B37 & Wall & Bughole & 3.75 & 3.75 & 0.00 & 0.41 & 1 & 14.1 & 5.8 \\
\hline 29 & & NP-B38 & Wall & Crack & 1.00 & 0.01 & 0.00 & 0.00 & 2 & 0.0 & 0.0 \\
\hline
\end{tabular}


Table 9. (continued).

\begin{tabular}{|c|c|c|c|c|c|c|c|c|c|c|c|}
\hline SNR & NCR & $\begin{array}{c}\text { Component } \\
\text { ID }^{\mathrm{a}}\end{array}$ & $\begin{array}{c}\text { Where } \\
\text { Damaged }\end{array}$ & $\begin{array}{c}\text { Nonconforming } \\
\text { Condition }\end{array}$ & $\begin{array}{c}\text { Length } \\
\text { (in) }\end{array}$ & $\begin{array}{c}\text { Width } \\
1 \\
\text { (in) } \\
\end{array}$ & $\begin{array}{c}\text { Width } \\
2 \\
\text { (in) } \\
\end{array}$ & $\begin{array}{c}\text { Depth } \\
\text { (in) }\end{array}$ & $\begin{array}{c}\text { Number of } \\
\text { Defects }\end{array}$ & $\begin{array}{c}\text { Defect } \\
\text { Area } \\
\left(\mathrm{in}^{2}\right) \\
\end{array}$ & $\begin{array}{c}\text { Defect } \\
\text { Volume } \\
\left(\text { in }^{3}\right)\end{array}$ \\
\hline 12 & & NP-B38 & Wall & Bughole & 3.75 & 3.75 & 0.00 & 0.41 & 1 & 14.1 & 5.8 \\
\hline 29 & & NP-B38 & Lift Lug & Crack & 1.00 & 0.01 & 0.00 & 0.00 & 2 & 0.0 & 0.0 \\
\hline 12 & & NP-B39 & Wall & Bughole & 3.75 & 3.75 & 0.00 & 0.41 & 1 & 14.1 & 5.8 \\
\hline 29 & & NP-B39 & Wall & Crack & 1.00 & 0.02 & 0.00 & 0.00 & 1 & 0.0 & 0.0 \\
\hline 12 & & NP-B41 & Wall & Bughole & 3.75 & 3.75 & 0.00 & 0.41 & 1 & 14.1 & 5.8 \\
\hline 29 & & NP-B42 & Lift Lug & Crack & 2.00 & 0.02 & 0.00 & 0.00 & 1 & 0.0 & 0.0 \\
\hline 29 & & NP-B42 & Lift Lug & Crack & 2.00 & 0.02 & 0.00 & 0.00 & 1 & 0.0 & 0.0 \\
\hline 43 & & NP-B42 & Wall & Honeycombing & 3.00 & 1.50 & 0.00 & 0.50 & 1 & 4.5 & 2.3 \\
\hline 42 & & NP-B43 & Wall & Honeycombing & 2.75 & 1.25 & 0.00 & 0.50 & 2 & 6.9 & 3.4 \\
\hline 36 & & NP-B47 & & & 0.00 & 0.00 & 0.00 & 0.00 & 0 & 0.0 & 0.0 \\
\hline 42 & & NP-B49 & Edge & Spalling & 1.25 & 1.00 & 0.00 & 0.50 & 1 & 1.3 & 0.6 \\
\hline 35 & & NP-B49 & & Bughole & 2.50 & 1.25 & 0.00 & 0.50 & 11 & 34.4 & 17.2 \\
\hline 35 & & NP-B49 & & Bughole & 2.50 & 1.25 & 0.00 & 0.50 & 11 & 34.4 & 17.2 \\
\hline \multirow[t]{2}{*}{36} & & NP-B49 & & & 0.00 & 0.00 & 0.00 & 0.00 & 0 & 0.0 & 0.0 \\
\hline & 35 & NP-B49 & Wall & Bughole & 2.50 & 1.25 & 0.00 & 0.50 & 1 & 3.1 & 1.6 \\
\hline 42 & & NP-B49 & Wall & Bughole & 1.50 & 0.75 & 0.00 & 0.38 & 11 & 12.4 & 4.6 \\
\hline \multirow[t]{2}{*}{35} & & NP-B51 & & Bughole & 2.38 & 1.31 & 0.00 & 0.19 & 19 & 59.2 & 11.1 \\
\hline & 35 & NP-B51 & Wall & Bughole & 2.38 & 1.31 & 0.00 & 0.19 & 1 & 3.1 & 0.6 \\
\hline 35 & & NP-B51 & & Bughole & 2.38 & 1.31 & 0.00 & 0.19 & 19 & 59.2 & 11.1 \\
\hline \multirow[t]{2}{*}{35} & & NP-B53 & & Bughole & 1.63 & 1.00 & 0.00 & 0.31 & 43 & 70.1 & 21.9 \\
\hline & 35 & NP-B53 & Wall & Bughole & 1.63 & 1.00 & 0.00 & 0.31 & 1 & 1.6 & 0.5 \\
\hline 35 & & NP-B53 & & Bughole & 1.63 & 1.00 & 0.00 & 0.31 & 43 & 70.1 & 21.9 \\
\hline \multirow[t]{2}{*}{35} & & NP-B54 & & Bughole & 1.75 & 1.00 & 0.00 & 0.25 & 11 & 19.2 & 4.8 \\
\hline & 35 & NP-B54 & Wall & Bughole & 1.75 & 1.00 & 0.00 & 0.25 & 1 & 1.8 & 0.4 \\
\hline 35 & & NP-B54 & & Bughole & 1.75 & 1.00 & 0.00 & 0.25 & 11 & 19.2 & 4.8 \\
\hline \multirow[t]{2}{*}{39} & & NP-B55 & Tongue & Spalling & 2.50 & 1.75 & 0.00 & 0.25 & 1 & 4.4 & 1.1 \\
\hline & 35 & NP-B57 & Wall & Honeycombing & 3.00 & 2.00 & 0.00 & 0.06 & 1 & 6.0 & 0.4 \\
\hline 35 & & NP-B57 & & Honeycombing & 3.00 & 2.00 & 0.00 & 0.06 & 1 & 6.0 & 0.4 \\
\hline
\end{tabular}


Table 9. (continued).

\begin{tabular}{|c|c|c|c|c|c|c|c|c|c|c|c|}
\hline SNR & NCR & $\begin{array}{c}\text { Component } \\
\text { ID }^{\mathbf{a}} \\
\end{array}$ & $\begin{array}{c}\text { Where } \\
\text { Damaged }\end{array}$ & $\begin{array}{c}\text { Nonconforming } \\
\text { Condition } \\
\end{array}$ & $\begin{array}{l}\text { Length } \\
\text { (in) }\end{array}$ & $\begin{array}{c}\text { Width } \\
1 \\
\text { (in) } \\
\end{array}$ & $\begin{array}{c}\text { Width } \\
2 \\
\text { (in) } \\
\end{array}$ & $\begin{array}{c}\text { Depth } \\
\text { (in) }\end{array}$ & $\begin{array}{c}\text { Number of } \\
\text { Defects }\end{array}$ & $\begin{array}{c}\text { Defect } \\
\text { Area } \\
\left(\text { in }^{2}\right) \\
\end{array}$ & $\begin{array}{c}\text { Defect } \\
\text { Volume } \\
\left(\text { in }^{3}\right)\end{array}$ \\
\hline 35 & & NP-B58 & & Bughole & 2.00 & 0.50 & 0.00 & 0.13 & 1 & 1.0 & 0.1 \\
\hline & 35 & NP-B58 & Wall & Bughole & 2.00 & 0.50 & 0.00 & 0.13 & 1 & 1.0 & 0.1 \\
\hline 36 & & NP-B58 & & & 0.00 & 0.00 & 0.00 & 0.00 & 0 & 0.0 & 0.0 \\
\hline 35 & & NP-B59 & & Bughole & 1.56 & 0.75 & 0.00 & 0.19 & 1 & 1.2 & 0.2 \\
\hline & 35 & NP-B59 & Wall & Bughole & 1.56 & 0.75 & 0.00 & 0.19 & 1 & 1.2 & 0.2 \\
\hline 35 & & NP-B60 & & Bughole & 2.00 & 1.00 & 0.00 & 0.50 & 1 & 2.0 & 1.0 \\
\hline & 35 & NP-B60 & Wall & Bughole & 2.00 & 1.00 & 0.00 & 0.50 & 1 & 2.0 & 1.0 \\
\hline 37 & & NP-P1 & Wall & Crack & 4.00 & 0.04 & 0.00 & 0.06 & 1 & 0.2 & 0.0 \\
\hline 37 & & NP-P1 & Edge & Spalling & 2.00 & 2.25 & 0.00 & 0.50 & 5 & 22.5 & 11.2 \\
\hline 37 & & NP-P2 & Edge & Spalling & 3.00 & 2.50 & 0.00 & 0.50 & 3 & 22.5 & 11.2 \\
\hline 12 & & NP-P2 & Wall & Bughole & 2.00 & 2.00 & 0.00 & 0.23 & 1 & 4.0 & 0.9 \\
\hline 86 & & NP-P2 & & Crack & 11.50 & 0.01 & 0.00 & 0.00 & 1 & 0.1 & 0.0 \\
\hline 37 & & NP-P3 & Edge & Spalling & 6.50 & 1.25 & 1.00 & 0.50 & 5 & 73.1 & 36.6 \\
\hline 12 & & NP-P3 & Wall & Bughole & 2.00 & 2.00 & 0.00 & 0.23 & 1 & 4.0 & 0.9 \\
\hline 86 & & NP-P3 & & Crack & 6.50 & 0.01 & 0.00 & 0.00 & 1 & 0.1 & 0.0 \\
\hline 37 & & NP-P4 & Edge & Spalling & 7.88 & 1.50 & 1.25 & 0.63 & 1 & 21.7 & 13.5 \\
\hline 37 & & NP-P4 & & Honeycombing & 3.75 & 1.88 & 0.00 & 0.50 & 5 & 35.2 & 17.6 \\
\hline 86 & & NP-P4 & & Crack & 5.50 & 0.01 & 0.00 & 0.00 & 1 & 0.1 & 0.0 \\
\hline 37 & & NP-P5 & Edge & Spalling & 2.00 & 1.25 & 0.00 & 0.50 & 1 & 2.5 & 1.3 \\
\hline 86 & & NP-P5 & & Crack & 11.00 & 0.01 & 0.00 & 0.00 & 1 & 0.1 & 0.0 \\
\hline 12 & & NP-P5 & Wall & Bughole & 2.00 & 2.00 & 0.00 & 0.23 & 1 & 4.0 & 0.9 \\
\hline 86 & & NP-P6 & & Crack & 7.00 & 0.01 & 0.00 & 0.00 & 1 & 0.1 & 0.0 \\
\hline 115 & & NP-P6 & Edge & Spalling & 16.50 & 0.63 & 6.50 & 0.88 & 1 & 118.0 & 103.0 \\
\hline 37 & & NP-P6 & Edge & Spalling & 11.90 & 1.25 & 1.00 & 0.50 & 6 & 161.0 & 80.3 \\
\hline 86 & & NP-P7 & & Crack Depth & 3.50 & 2.00 & 2.25 & 1.84 & 1 & 14.9 & 27.4 \\
\hline 86 & & NP-P7 & & Crack Depth & 5.00 & 2.50 & 0.00 & 0.41 & 1 & 12.5 & 5.1 \\
\hline 158 & & NP-P7 & Edge & Spalling & 6.00 & 2.50 & 0.50 & 0.50 & 1 & 18.0 & 9.0 \\
\hline 86 & & NP-P7 & & Crack Depth & 5.00 & 1.38 & 1.50 & 0.88 & 1 & 14.4 & 12.6 \\
\hline
\end{tabular}


Table 9. (continued).

\begin{tabular}{|c|c|c|c|c|c|c|c|c|c|c|c|}
\hline SNR & NCR & $\begin{array}{c}\text { Component } \\
\text { ID }^{\mathbf{a}} \\
\end{array}$ & $\begin{array}{c}\text { Where } \\
\text { Damaged }\end{array}$ & $\begin{array}{c}\text { Nonconforming } \\
\text { Condition } \\
\end{array}$ & $\begin{array}{l}\text { Length } \\
\text { (in) }\end{array}$ & $\begin{array}{c}\text { Width } \\
1 \\
\text { (in) } \\
\end{array}$ & $\begin{array}{c}\text { Width } \\
2 \\
\text { (in) } \\
\end{array}$ & $\begin{array}{c}\text { Depth } \\
\text { (in) }\end{array}$ & $\begin{array}{c}\text { Number of } \\
\text { Defects }\end{array}$ & $\begin{array}{c}\text { Defect } \\
\text { Area } \\
\left(\text { in }^{2}\right) \\
\end{array}$ & $\begin{array}{c}\text { Defect } \\
\text { Volume } \\
\left(\text { in }^{3}\right)\end{array}$ \\
\hline 86 & & NP-P7 & & Crack Depth & 2.50 & 4.25 & 0.00 & 0.50 & 1 & 10.6 & 5.3 \\
\hline 12 & & NP-P7 & Wall & Bughole & 2.00 & 2.00 & 0.00 & 0.23 & 1 & 4.0 & 0.9 \\
\hline 158 & & NP-P7 & Edge & Spalling & 6.00 & 1.50 & 0.50 & 0.50 & 1 & 12.0 & 6.0 \\
\hline 86 & & NP-P7 & & Crack & 20.00 & 0.02 & 0.00 & 0.00 & 1 & 0.4 & 0.0 \\
\hline 37 & & NP-P7 & Edge & Spalling & 9.00 & 1.00 & 0.75 & 0.25 & 2 & 31.5 & 7.9 \\
\hline 37 & & NP-P8 & & Honeycombing & 1.50 & 1.00 & 0.00 & 0.88 & 1 & 1.5 & 1.3 \\
\hline 12 & & NP-P8 & Wall & Bughole & 2.00 & 2.00 & 0.00 & 0.23 & 1 & 4.0 & 0.9 \\
\hline 37 & & NP-P8 & Edge & Spalling & 2.00 & 1.00 & 1.25 & 0.13 & 1 & 4.5 & 0.6 \\
\hline 86 & & NP-P9 & & Crack & 8.00 & 0.01 & 0.00 & 0.00 & 1 & 0.1 & 0.0 \\
\hline 111 & & NP-P10 & Edge & Spalling & 8.50 & 1.25 & 4.50 & 0.75 & 1 & 48.9 & 36.7 \\
\hline 37 & & NP-P10 & & Honeycombing & 2.00 & 1.25 & 0.00 & 0.88 & 2 & 5.0 & 4.4 \\
\hline 37 & & NP-P10 & Edge & Spalling & 2.00 & 1.25 & 0.88 & 0.63 & 3 & 12.8 & 8.0 \\
\hline 37 & & NP-P11 & Edge & Spalling & 2.50 & 1.00 & 1.00 & 0.75 & 1 & 5.0 & 3.8 \\
\hline 12 & & NP-P11 & Wall & Bughole & 2.00 & 2.00 & 0.00 & 0.23 & 1 & 4.0 & 0.9 \\
\hline 157 & & NP-P12 & Edge & Spalling & 24.00 & 2.50 & 1.00 & 0.88 & 1 & 84.0 & 73.9 \\
\hline 37 & & NP-P12 & Edge & Spalling & 1.88 & 1.75 & 1.50 & 0.88 & 1 & 6.1 & 5.4 \\
\hline 12 & & NP-P13 & Wall & Bughole & 2.00 & 2.00 & 0.00 & 0.23 & 1 & 4.0 & 0.9 \\
\hline 37 & & NP-P13 & Edge & Spalling & 1.88 & 1.00 & 1.25 & 0.63 & 1 & 4.2 & 2.6 \\
\hline 37 & & NP-P13 & & Honeycombing & 6.50 & 3.00 & 0.00 & 0.50 & 4 & 78.0 & 39.0 \\
\hline 157 & & NP-P14 & Corner & Spalling & 6.75 & 8.00 & 6.75 & 0.00 & 1 & 99.6 & 0.0 \\
\hline 12 & & NP-P14 & Wall & Bughole & 2.00 & 2.00 & 0.00 & 0.23 & 1 & 4.0 & 0.9 \\
\hline 37 & & NP-P15 & Edge & Spalling & 36.00 & 2.00 & 0.00 & 0.25 & 4 & 288.0 & 72.0 \\
\hline 37 & & NP-P15 & Edge & Spalling & 2.63 & 1.25 & 0.00 & 0.25 & 1 & 3.3 & 0.8 \\
\hline 37 & & NP-P15 & & Bughole & 1.25 & 0.50 & 0.00 & 0.50 & 2 & 1.3 & 0.6 \\
\hline 37 & & NP-P16 & Edge & Spalling & 2.00 & 1.25 & 0.00 & 0.50 & 1 & 2.5 & 1.3 \\
\hline 37 & & NP-P18 & Edge & Spalling & 3.50 & 1.25 & 0.88 & 0.63 & 2 & 14.9 & 9.3 \\
\hline 37 & & NP-P18 & & Honeycombing & 2.13 & 1.25 & 0.00 & 0.50 & 2 & 5.3 & 2.7 \\
\hline 37 & & NP-P19 & Edge & Spalling & 2.38 & 1.25 & 0.88 & 0.63 & 2 & 10.1 & 6.3 \\
\hline
\end{tabular}


Table 9. (continued).

\begin{tabular}{|c|c|c|c|c|c|c|c|c|c|c|c|}
\hline SNR & NCR & $\begin{array}{c}\text { Component } \\
\text { ID }^{\mathbf{a}} \\
\end{array}$ & $\begin{array}{c}\text { Where } \\
\text { Damaged }\end{array}$ & $\begin{array}{c}\text { Nonconforming } \\
\text { Condition } \\
\end{array}$ & $\begin{array}{l}\text { Length } \\
\text { (in) }\end{array}$ & $\begin{array}{c}\text { Width } \\
1 \\
\text { (in) } \\
\end{array}$ & $\begin{array}{c}\text { Width } \\
2 \\
\text { (in) } \\
\end{array}$ & $\begin{array}{c}\text { Depth } \\
\text { (in) }\end{array}$ & $\begin{array}{c}\text { Number of } \\
\text { Defects }\end{array}$ & $\begin{array}{c}\text { Defect } \\
\text { Area } \\
\left(\text { in }^{2}\right) \\
\end{array}$ & $\begin{array}{c}\text { Defect } \\
\text { Volume } \\
\left(\text { in }^{3}\right)\end{array}$ \\
\hline 37 & & NP-P19 & & Honeycombing & 5.00 & 2.75 & 0.00 & 0.38 & 7 & 96.2 & 36.1 \\
\hline 86 & & NP-P19 & & Crack & 11.00 & 0.01 & 0.00 & 0.00 & 1 & 0.1 & 0.0 \\
\hline 157 & & NP-P20 & Corner & Spalling & 5.00 & 3.13 & 5.00 & 0.00 & 1 & 40.7 & 0.0 \\
\hline 12 & & NP-P21 & Wall & Bughole & 2.00 & 2.00 & 0.00 & 0.23 & 1 & 4.0 & 0.9 \\
\hline 37 & & NP-P23 & Edge & Spalling & 1.25 & 0.88 & 0.38 & 0.25 & 4 & 6.3 & 1.6 \\
\hline 37 & & NP-P23 & & Honeycombing & 8.00 & 3.75 & 0.00 & 0.38 & 3 & 90.0 & 33.8 \\
\hline 37 & & NP-P24 & Edge & Spalling & 1.50 & 1.25 & 0.88 & 0.25 & 3 & 9.6 & 2.4 \\
\hline 37 & & NP-P25 & Edge & Spalling & 1.25 & 1.25 & 0.00 & 0.50 & 2 & 3.1 & 1.6 \\
\hline 12 & & NP-P25 & Wall & Bughole & 2.00 & 2.00 & 0.00 & 0.23 & 1 & 4.0 & 0.9 \\
\hline 37 & & NP-P26 & & Honeycombing & 8.50 & 3.50 & 0.00 & 0.38 & 2 & 59.5 & 22.3 \\
\hline 37 & & NP-P26 & & Bughole & 2.50 & 0.38 & 0.00 & 0.38 & 5 & 4.7 & 1.8 \\
\hline 37 & & NP-P26 & Edge & Spalling & 3.50 & 0.88 & 0.25 & 0.25 & 2 & 7.9 & 2.0 \\
\hline 157 & & NP-P26 & Edge & Spalling & 27.20 & 4.00 & 1.25 & 1.00 & 1 & 143.0 & 143.0 \\
\hline 157 & & NP-P30 & Corner & Spalling & 8.50 & 3.50 & 8.50 & 0.00 & 1 & 102.0 & 0.0 \\
\hline 12 & & NP-P31 & Wall & Bughole & 2.00 & 2.00 & 0.00 & 0.23 & 1 & 4.0 & 0.9 \\
\hline 12 & & NP-P35 & Wall & Bughole & 2.00 & 2.00 & 0.00 & 0.23 & 1 & 4.0 & 0.9 \\
\hline 35 & & NP-P37 & & Honeycombing & 5.00 & 1.00 & 0.00 & 0.50 & 3 & 15.0 & 7.5 \\
\hline & 35 & NP-P37 & Wall & Honeycombing & 5.00 & 1.00 & 0.00 & 0.50 & 3 & 15.0 & 7.5 \\
\hline 35 & & NP-P37 & & Honeycombing & 5.00 & 1.00 & 0.00 & 0.50 & 3 & 15.0 & 7.5 \\
\hline 37 & & NP-P37 & Edge & Spalling & 1.00 & 1.00 & 0.00 & 0.63 & 2 & 2.0 & 1.3 \\
\hline 12 & & NP-P38 & Wall & Bughole & 2.00 & 2.00 & 0.00 & 0.23 & 1 & 4.0 & 0.9 \\
\hline 157 & & NP-P38 & Corner & Spalling & 3.75 & 1.50 & 3.75 & 0.00 & 1 & 19.7 & 0.0 \\
\hline 111 & & NP-P39 & Edge & Spalling & 8.00 & 1.25 & 3.00 & 0.75 & 1 & 34.0 & 25.5 \\
\hline 111 & & NP-P39 & Edge & Spalling & 6.50 & 1.00 & 5.00 & 0.63 & 1 & 39.0 & 24.4 \\
\hline 37 & & NP-P39 & Edge & Spalling & 2.50 & 1.00 & 0.75 & 0.75 & 1 & 4.4 & 3.3 \\
\hline 157 & & NP-P42 & Corner & Spalling & 4.00 & 8.50 & 4.00 & 0.00 & 1 & 50.0 & 0.0 \\
\hline 86 & & NP-P45 & & Crack & 14.80 & 0.01 & 0.00 & 0.00 & 1 & 0.2 & 0.0 \\
\hline 109 & & NP-P49 & Edge & Spalling & 4.50 & 0.75 & 3.50 & 0.75 & 1 & 19.1 & 14.3 \\
\hline
\end{tabular}


Table 9. (continued).

\begin{tabular}{|c|c|c|c|c|c|c|c|c|c|c|c|}
\hline SNR & NCR & $\begin{array}{c}\text { Component } \\
\text { ID }^{\mathrm{a}} \\
\end{array}$ & $\begin{array}{c}\text { Where } \\
\text { Damaged }\end{array}$ & $\begin{array}{c}\text { Nonconforming } \\
\text { Condition }\end{array}$ & $\begin{array}{l}\text { Length } \\
\text { (in) }\end{array}$ & $\begin{array}{c}\text { Width } \\
1 \\
\text { (in) } \\
\end{array}$ & $\begin{array}{c}\text { Width } \\
2 \\
\text { (in) } \\
\end{array}$ & $\begin{array}{l}\text { Depth } \\
\text { (in) }\end{array}$ & $\begin{array}{c}\text { Number of } \\
\text { Defects }\end{array}$ & $\begin{array}{c}\text { Defect } \\
\text { Area } \\
\left(\text { in }^{2}\right) \\
\end{array}$ & $\begin{array}{c}\text { Defect } \\
\text { Volume } \\
\left(\text { in }^{3}\right)\end{array}$ \\
\hline 109 & & NP-P49 & Edge & Spalling & 10.00 & 0.25 & 3.00 & 0.25 & 1 & 32.5 & 8.1 \\
\hline 157 & & NP-P52 & Edge & Spalling & 18.80 & 3.00 & 1.00 & 1.00 & 1 & 75.0 & 75.0 \\
\hline 86 & & NP-P53 & & Crack & 11.80 & 0.01 & 0.00 & 0.00 & 1 & 0.1 & 0.0 \\
\hline 37 & & NP-P53 & Edge & Spalling & 3.50 & 1.25 & 0.75 & 0.25 & 1 & 7.0 & 1.8 \\
\hline \multirow[t]{2}{*}{35} & & NP-P55 & & Bughole & 1.75 & 0.50 & 0.00 & 0.25 & 1 & 0.9 & 0.2 \\
\hline & 35 & NP-P55 & Wall & Bughole & 1.75 & 0.50 & 0.00 & 0.25 & 1 & 0.9 & 0.2 \\
\hline \multirow[t]{2}{*}{35} & & NP-P56 & & Bughole & 1.00 & 0.63 & 0.00 & 1.00 & 1 & 0.6 & 0.6 \\
\hline & 35 & NP-P56 & Wall & Bughole & 1.00 & 0.63 & 0.00 & 1.00 & 1 & 0.6 & 0.6 \\
\hline \multirow[t]{2}{*}{35} & & NP-P57 & & Bughole & 4.00 & 1.00 & 0.00 & 0.13 & 1 & 4.0 & 0.5 \\
\hline & 35 & NP-P57 & Wall & Bughole & 4.00 & 1.00 & 0.00 & 0.13 & 3 & 12.0 & 1.5 \\
\hline 77 & & FTC-U1A & Top Edge & Spalling & 4.00 & 0.13 & 1.88 & 1.00 & 4 & 32.1 & 32.1 \\
\hline 77 & & FTC-U1A & & Honeycombing & 8.25 & 0.88 & 0.00 & 0.06 & 2 & 14.4 & 0.9 \\
\hline 77 & & FTC-U9 & $\begin{array}{l}\text { Bottom } \\
\text { Edge }\end{array}$ & Spalling & 10.50 & 3.63 & 2.00 & 1.88 & 2 & 118.0 & 222.0 \\
\hline 76 & & FTC-U10 & & Bughole & 1.00 & 0.75 & 0.00 & 1.06 & 1 & 0.8 & 0.8 \\
\hline 95 & & FTC-U14 & Tongue & Spalling & 17.00 & 3.00 & 0.00 & 4.50 & 1 & 51.0 & 230.0 \\
\hline 95 & & FTC-U14 & Tongue & Spalling & 17.00 & 2.63 & 0.00 & 4.25 & 1 & 44.7 & 190.0 \\
\hline 98 & 18 & FTC-U21 & Edge & Spalling & 16.00 & 2.00 & 3.00 & 3.50 & 1 & 80.0 & 280.0 \\
\hline \multirow[t]{2}{*}{98} & & FTC-U21 & Edge & Spalling & 16.00 & 3.00 & 0.00 & 3.50 & 1 & 48.0 & 168.0 \\
\hline & 27 & FTC-U22 & Edge & Spalling & 6.50 & 0.75 & 2.50 & 0.50 & 1 & 21.1 & 10.6 \\
\hline 96 & 28 & FTC-U24 & Edge & Spalling & 10.50 & 9.00 & 1.50 & 0.50 & 1 & 110.0 & 55.1 \\
\hline 130 & 47 & FTC-U24 & Edge & Spalling & 15.50 & 3.50 & 1.50 & 3.50 & 1 & 77.5 & 271.0 \\
\hline 76 & & FTC-U26 & & Honeycombing & 8.50 & 6.00 & 0.00 & 1.25 & 1 & 51.0 & 63.8 \\
\hline 70 & 12 & FTC-U29 & Edge & Spalling & 3.50 & 1.75 & 0.44 & 0.38 & 1 & 7.7 & 2.9 \\
\hline 76 & & FTC-U31 & & Crack & 6.75 & 0.01 & 0.00 & 0.03 & 1 & 0.1 & 0.0 \\
\hline 76 & & FTC-U34 & & Honeycombing & 7.50 & 5.00 & 1.25 & 1.38 & 1 & 46.9 & 64.7 \\
\hline 120 & & FTC-U34 & Edge & Spalling & 10.00 & 5.00 & 0.00 & 0.88 & 1 & 50.0 & 43.8 \\
\hline 77 & & FTC-U34 & & Honeycombing & 7.50 & 5.00 & 0.00 & 1.38 & 1 & 37.5 & 51.8 \\
\hline 77 & & FTC-U34 & & Crack & 2.75 & 0.01 & 0.00 & 0.13 & 1 & 0.0 & 0.0 \\
\hline
\end{tabular}


Table 9. (continued).

\begin{tabular}{|c|c|c|c|c|c|c|c|c|c|c|c|}
\hline SNR & NCR & $\begin{array}{c}\text { Component } \\
\text { ID }^{\mathrm{a}}\end{array}$ & $\begin{array}{c}\text { Where } \\
\text { Damaged }\end{array}$ & $\begin{array}{c}\text { Nonconforming } \\
\text { Condition }\end{array}$ & $\begin{array}{l}\text { Length } \\
\text { (in) }\end{array}$ & $\begin{array}{c}\text { Width } \\
1 \\
\text { (in) }\end{array}$ & $\begin{array}{c}\text { Width } \\
2 \\
\text { (in) }\end{array}$ & $\begin{array}{l}\text { Depth } \\
\text { (in) }\end{array}$ & $\begin{array}{l}\text { Number of } \\
\text { Defects }\end{array}$ & $\begin{array}{c}\text { Defect } \\
\text { Area } \\
\left(\text { in }^{2}\right)\end{array}$ & $\begin{array}{c}\text { Defect } \\
\text { Volume } \\
\left(\text { in }^{3}\right)\end{array}$ \\
\hline 77 & & FTC-U37 & $\begin{array}{l}\text { Bottom } \\
\text { Edge }\end{array}$ & Spalling & 8.00 & 7.00 & 1.75 & 1.13 & 1 & 70.0 & 79.1 \\
\hline 130 & 46 & FTC-U37 & Edge & Spalling & 8.00 & 1.00 & 6.50 & 1.00 & 1 & 60.0 & 60.0 \\
\hline 77 & & FTC-U37 & Tongue & Spalling & 27.10 & 3.25 & 0.00 & 3.25 & 1 & 88.1 & 286.0 \\
\hline 130 & 46 & FTC-U37 & Edge & Spalling & 23.00 & 3.50 & 2.00 & 3.50 & 1 & 126.0 & 443.0 \\
\hline & 25 & FTC-U50 & Edge & Spalling & 8.00 & 6.00 & 1.50 & 1.00 & 1 & 60.0 & 60.0 \\
\hline & 21 & FTC-U51 & Edge & Spalling & 10.00 & 7.00 & 1.00 & 0.63 & 1 & 80.0 & 50.0 \\
\hline 77 & & FTC-U54 & & Parition & 13.00 & 3.00 & 1.25 & 0.63 & 1 & 55.2 & 34.5 \\
\hline 77 & & FTC-U54 & Top Edge & Spalling & 10.00 & 3.25 & 2.00 & 1.25 & 1 & 52.5 & 65.6 \\
\hline 77 & & FTC-U79 & & Crack & 5.25 & 0.02 & 0.00 & 0.00 & 1 & 0.1 & 0.0 \\
\hline 127 & & FTC-U80 & $\begin{array}{l}\text { Inner } \\
\text { partition }\end{array}$ & Crack & 27.00 & 0.03 & 0.00 & 0.00 & 3 & 2.0 & 0.0 \\
\hline 101 & & FTC-U80 & Top Edge & Spalling & 7.75 & 1.38 & 3.13 & 0.75 & 1 & 35.0 & 26.2 \\
\hline 127 & & FTC-U80 & $\begin{array}{l}\text { Inner } \\
\text { partition }\end{array}$ & Crack & 10.50 & 0.02 & 0.00 & 0.00 & 1 & 0.2 & 0.0 \\
\hline 120 & & FTC-U86 & & Honeycombing & 49.00 & 3.00 & 0.00 & 1.25 & 1 & 147.0 & 184.0 \\
\hline 123 & & FTC-U87 & $\begin{array}{l}\text { Inner } \\
\text { partition }\end{array}$ & Spalling & 11.00 & 3.25 & 0.00 & 1.25 & 1 & 35.8 & 44.7 \\
\hline 123 & & FTC-U90 & $\begin{array}{l}\text { Inner } \\
\text { partition }\end{array}$ & Spalling & 24.00 & 8.50 & 0.00 & 2.00 & 1 & 204.0 & 408.0 \\
\hline 132 & & FTC-U91 & Edge & Spalling & 57.00 & 3.50 & 3.50 & 0.50 & 1 & 399.0 & 200.0 \\
\hline 77 & & FTC-B1A & Top Edge & Spalling & 4.19 & 2.75 & 1.25 & 0.38 & 1 & 16.8 & 6.3 \\
\hline 76 & & FTC-B8 & Edge & Spalling & 2.00 & 1.50 & 0.88 & 0.25 & 1 & 4.8 & 1.2 \\
\hline 77 & & FTC-B10 & Top Edge & Spalling & 8.50 & 3.13 & 2.25 & 1.13 & 1 & 45.7 & 51.7 \\
\hline 77 & & FTC-B13 & Top Edge & Spalling & 6.00 & 2.00 & 1.88 & 1.00 & 1 & 23.3 & 23.3 \\
\hline 76 & & FTC-B15 & Edge & Spalling & 6.00 & 2.13 & 1.38 & 1.13 & 1 & 21.1 & 23.8 \\
\hline 90 & 20 & FTC-B26 & Edge & Spalling & 12.50 & 3.25 & 0.63 & 0.50 & 1 & 48.4 & 24.2 \\
\hline 89 & 19 & FTC-B28 & Edge & Spalling & 7.00 & 4.00 & 0.75 & 0.75 & 2 & 66.5 & 49.9 \\
\hline 104 & & FTC-B34 & Edge & Spalling & 5.50 & 0.88 & 6.00 & 0.88 & 1 & 37.8 & 33.1 \\
\hline 102 & & FTC-B72 & Edge & Spalling & 24.00 & 1.88 & 16.00 & 1.88 & 1 & 429.0 & 807.0 \\
\hline
\end{tabular}


Table 9. (continued).

\begin{tabular}{|c|c|c|c|c|c|c|c|c|c|c|c|}
\hline SNR & NCR & $\begin{array}{c}\text { Component } \\
\text { ID }^{\mathbf{a}} \\
\end{array}$ & $\begin{array}{c}\text { Where } \\
\text { Damaged }\end{array}$ & $\begin{array}{c}\text { Nonconforming } \\
\text { Condition } \\
\end{array}$ & $\begin{array}{c}\text { Length } \\
\text { (in) }\end{array}$ & $\begin{array}{c}\text { Width } \\
1 \\
\text { (in) } \\
\end{array}$ & $\begin{array}{c}\text { Width } \\
2 \\
\text { (in) }\end{array}$ & $\begin{array}{c}\begin{array}{c}\text { Depth } \\
\text { (in) }\end{array} \\
\end{array}$ & $\begin{array}{c}\text { Number of } \\
\text { Defects }\end{array}$ & $\begin{array}{c}\text { Defect } \\
\text { Area } \\
\left(\text { in }^{2}\right)\end{array}$ & $\begin{array}{c}\begin{array}{c}\text { Defect } \\
\text { Volume } \\
\left(\text { in }^{3}\right)\end{array} \\
\end{array}$ \\
\hline 131 & & FTC-B79 & Liftlug & Spalling & 0.63 & 0.50 & 0.00 & 1.25 & 5 & 1.6 & 2.0 \\
\hline 82 & & FTC-P4 & Edge & Spalling & 3.00 & 2.00 & 1.00 & 2.00 & 0 & 0.0 & 0.0 \\
\hline 87 & & FTC-P4 & Edge & Spalling & 3.00 & 2.00 & 1.00 & 2.00 & 2 & 18.0 & 36.0 \\
\hline 116 & & FTC-P7 & Edge & Spalling & 6.00 & 2.38 & 1.00 & 1.25 & 1 & 20.3 & 25.4 \\
\hline 156 & & FTC-P10 & Corner & Spalling & 7.00 & 3.25 & 7.00 & 0.00 & 1 & 71.8 & 0.0 \\
\hline 82 & & FTC-P11 & Edge & Spalling & 2.00 & 2.50 & 1.25 & 0.13 & 2 & 15.0 & 1.9 \\
\hline 82 & & FTC-P13 & Edge & Spalling & 2.88 & 2.00 & 0.94 & 0.50 & 1 & 8.5 & 4.2 \\
\hline \multirow[t]{2}{*}{82} & & FTC-P17 & Edge & Spalling & 3.00 & 1.63 & 0.81 & 0.88 & 2 & 14.7 & 12.8 \\
\hline & 29 & FTC-P38 & Edge & Spalling & 5.00 & 0.44 & 1.75 & 0.25 & 1 & 10.9 & 2.7 \\
\hline 156 & & FTC-P40 & Edge & Spalling & 5.00 & 2.50 & 1.25 & 0.75 & 1 & 18.8 & 14.1 \\
\hline \multirow[t]{2}{*}{158} & & FTC-P42 & Corner & Spalling & 4.50 & 2.00 & 4.50 & 0.00 & 1 & 29.2 & 0.0 \\
\hline & 23 & FTC-P46 & Wall & Crack & 9.00 & 0.01 & 0.00 & 0.00 & 2 & 0.2 & 0.0 \\
\hline 82 & & FTC-P48 & Edge & Spalling & 8.50 & 6.50 & 3.04 & 1.75 & 1 & 81.1 & 142.0 \\
\hline \multirow[t]{2}{*}{87} & & FTC-P48 & Edge & Spalling & 8.50 & 6.50 & 2.00 & 1.75 & 1 & 72.2 & 126.0 \\
\hline & 23 & FTC-P50 & Wall & Crack & 4.50 & 0.01 & 0.00 & 0.00 & 1 & 0.0 & 0.0 \\
\hline \multirow[t]{2}{*}{116} & & FTC-P58 & Edge & Spalling & 3.38 & 2.50 & 0.50 & 0.50 & 1 & 10.1 & 5.1 \\
\hline & 31 & FTC-P60 & Liftlug & Spalling & 0.00 & 0.00 & 0.00 & 0.50 & 1 & 0.0 & 0.0 \\
\hline 87 & & FTC-P62 & & Honeycombing & 14.00 & 1.00 & 0.00 & 1.62 & 1 & 14.0 & 22.7 \\
\hline 87 & & FTC-P62 & & Honeycombing & 16.00 & 1.00 & 0.00 & 1.03 & 1 & 16.0 & 16.5 \\
\hline 87 & & FTC-P64 & & Honeycombing & 19.00 & 1.00 & 0.00 & 1.48 & 1 & 19.0 & 28.1 \\
\hline 156 & & FTC-P64 & Edge & Spalling & 5.25 & 2.88 & 1.00 & 0.75 & 1 & 20.4 & 15.3 \\
\hline \multirow[t]{2}{*}{156} & & FTC-P66 & Corner & Spalling & 6.50 & 6.00 & 6.50 & 0.00 & 1 & 81.2 & 0.0 \\
\hline & 29 & FTC-P69 & & Crack & 3.00 & 0.01 & 0.00 & 0.00 & 1 & 0.0 & 0.0 \\
\hline 156 & & FTC-P84 & Edge & Spalling & 13.50 & 2.63 & 1.00 & 0.63 & 1 & 49.0 & 30.9 \\
\hline 119 & & FTC-P84 & Edge & Spalling & 15.30 & 2.25 & 8.50 & 2.13 & 1 & 164.0 & 350.0 \\
\hline 119 & & FTC-P84 & Edge & Spalling & 5.00 & 4.50 & 1.75 & 0.25 & 1 & 31.2 & 7.8 \\
\hline 108 & & FTC-P88 & Edge & Spalling & 4.00 & 2.38 & 0.94 & 0.50 & 1 & 13.3 & 6.6 \\
\hline 108 & & FTC-P88 & & Crack & 2.50 & 0.01 & 0.00 & 0.00 & 1 & 0.0 & 0.0 \\
\hline
\end{tabular}


Table 9. (continued).

\begin{tabular}{|c|c|c|c|c|c|c|c|c|c|c|c|}
\hline SNR & NCR & $\begin{array}{c}\text { Component } \\
\text { ID }^{\mathbf{a}} \\
\end{array}$ & $\begin{array}{c}\text { Where } \\
\text { Damaged }\end{array}$ & $\begin{array}{c}\text { Nonconforming } \\
\text { Condition } \\
\end{array}$ & $\begin{array}{c}\text { Length } \\
\text { (in) }\end{array}$ & $\begin{array}{c}\text { Width } \\
1 \\
\text { (in) } \\
\end{array}$ & $\begin{array}{c}\text { Width } \\
2 \\
\text { (in) } \\
\end{array}$ & $\begin{array}{c}\text { Depth } \\
\text { (in) }\end{array}$ & $\begin{array}{c}\text { Number of } \\
\text { Defects }\end{array}$ & $\begin{array}{c}\text { Defect } \\
\text { Area } \\
\left(\text { in }^{2}\right) \\
\end{array}$ & $\begin{array}{c}\text { Defect } \\
\text { Volume } \\
\left(\text { in }^{3}\right)\end{array}$ \\
\hline 156 & & FTC-P90 & Edge & Spalling & 5.75 & 2.13 & 0.88 & 0.75 & 1 & 17.3 & 13.0 \\
\hline 27 & & PA-U2 & Wall & Bughole & 2.25 & 2.25 & 0.00 & 0.11 & 1 & 5.1 & 0.6 \\
\hline 27 & & PA-B1 & Wall & Bughole & 1.88 & 1.88 & 0.00 & 0.26 & 4 & 14.1 & 3.7 \\
\hline 27 & & PA-B2 & Wall & Bughole & 1.88 & 1.88 & 0.00 & 0.26 & 4 & 14.1 & 3.7 \\
\hline 154 & & PA-PA1 & Edge & Spalling & 6.25 & 2.75 & 2.00 & 0.00 & 1 & 29.7 & 0.0 \\
\hline 154 & & PA-PA2 & Edge & Spalling & 5.00 & 1.00 & 2.25 & 0.75 & 1 & 16.2 & 12.2 \\
\hline 28 & & PA-P1 & Edge & Spalling & 1.50 & 3.00 & 3.00 & 0.37 & 1 & 9.0 & 3.3 \\
\hline 12 & & PA-P1 & Wall & Bughole & 2.00 & 2.00 & 0.00 & 0.23 & 1 & 4.0 & 0.9 \\
\hline
\end{tabular}

a. $\mathrm{U}=$ upper rise $\mathrm{B}=\mathrm{PA}$ - $\mathrm{P}$ -

b. Component NP-B2 was rejected based on the maximum crack width and the number of cracks found in this component. The defect/damage and crack dimensions are reported here for completeness. 


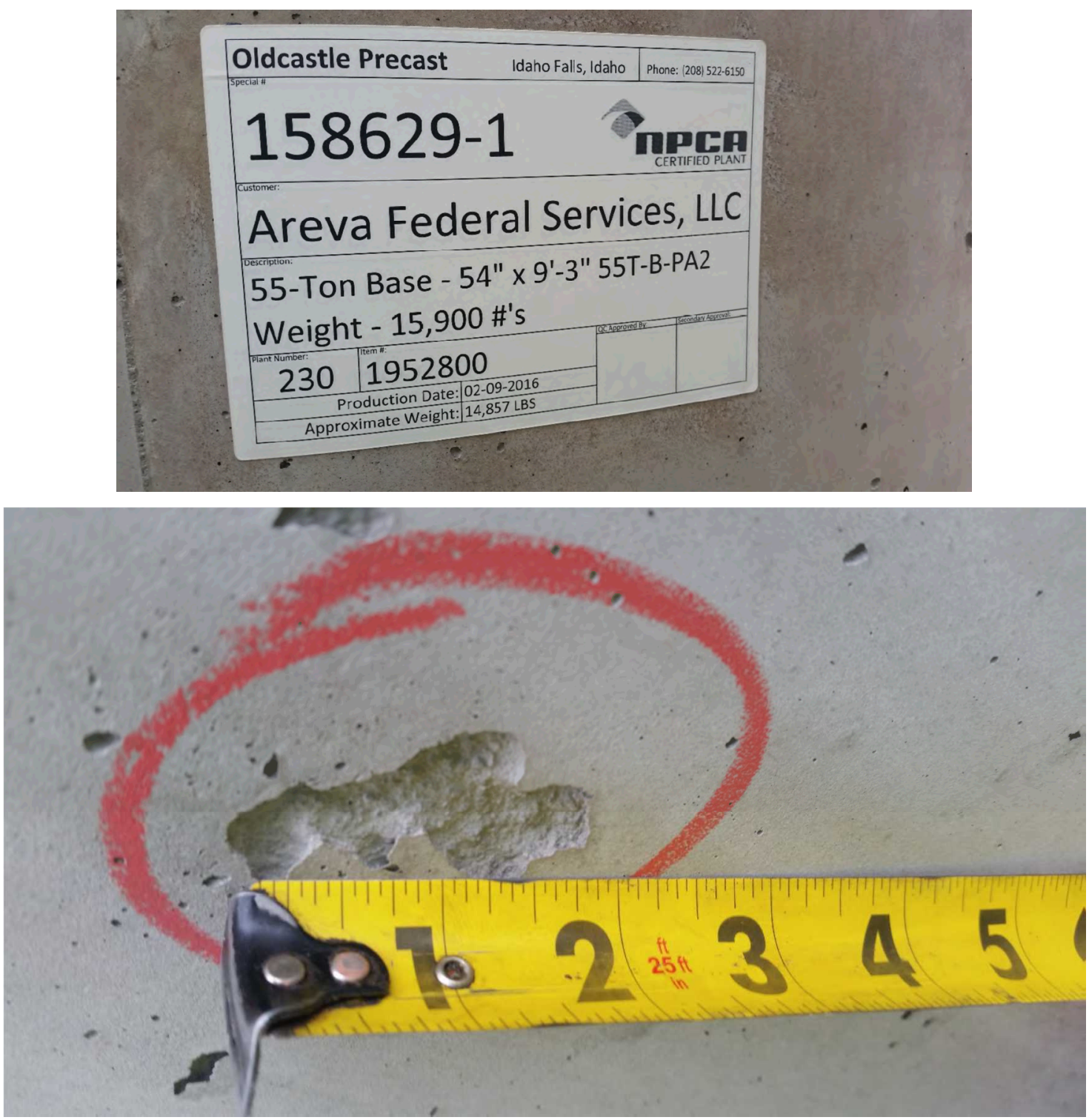

Figure 4. Example photograph of a bughole with measurement from SNR-027. The damage relative to the component dimensions is quantified in Table 9 and is insignificant. 

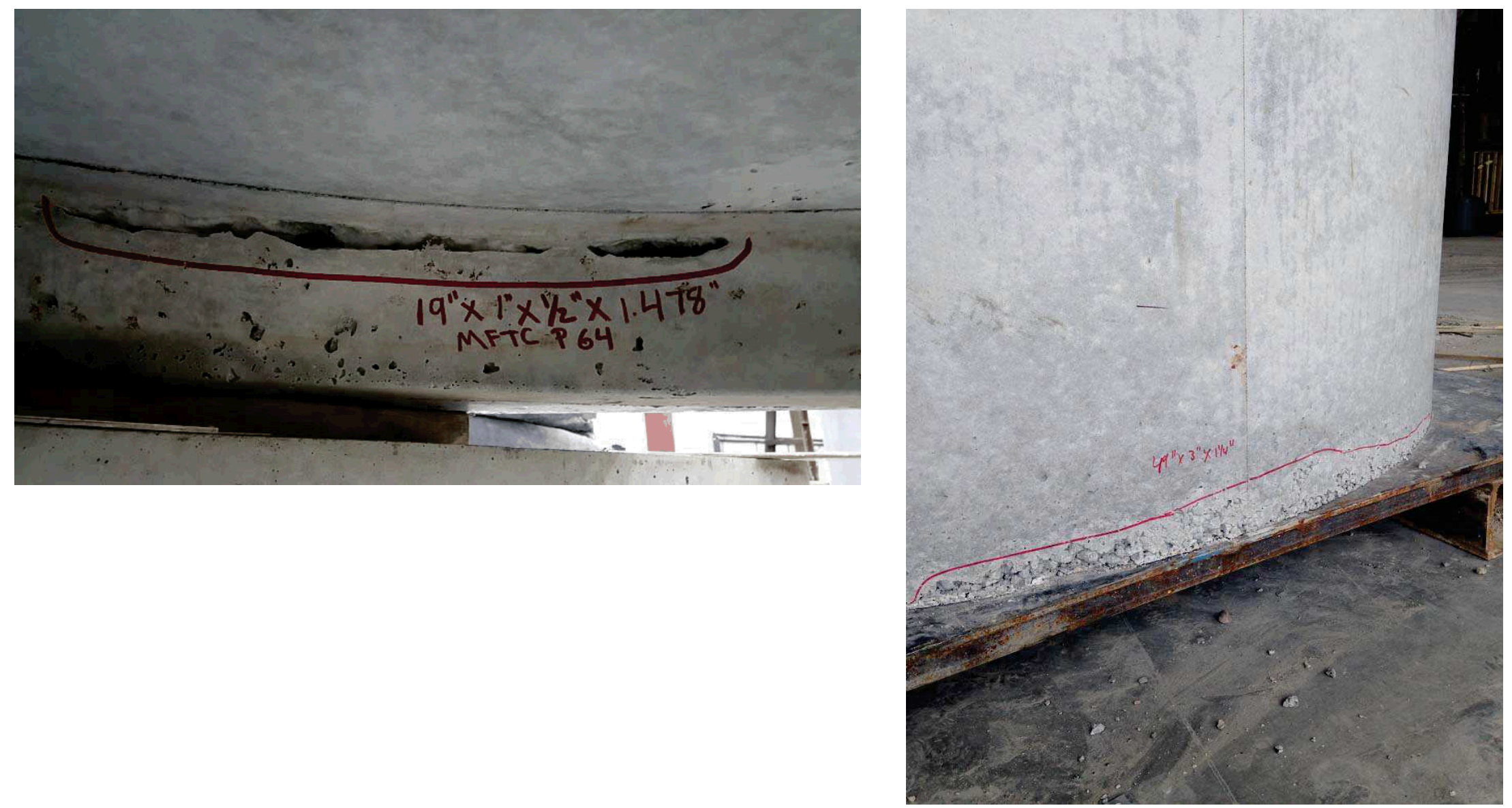

Figure 5. Example photograph of honeycombing along tongue edge from SNR-087 (left) and along bottom edge from SNR-120 (right). The damage relative to the component dimensions is quantified in Table 9 and is insignificant. 

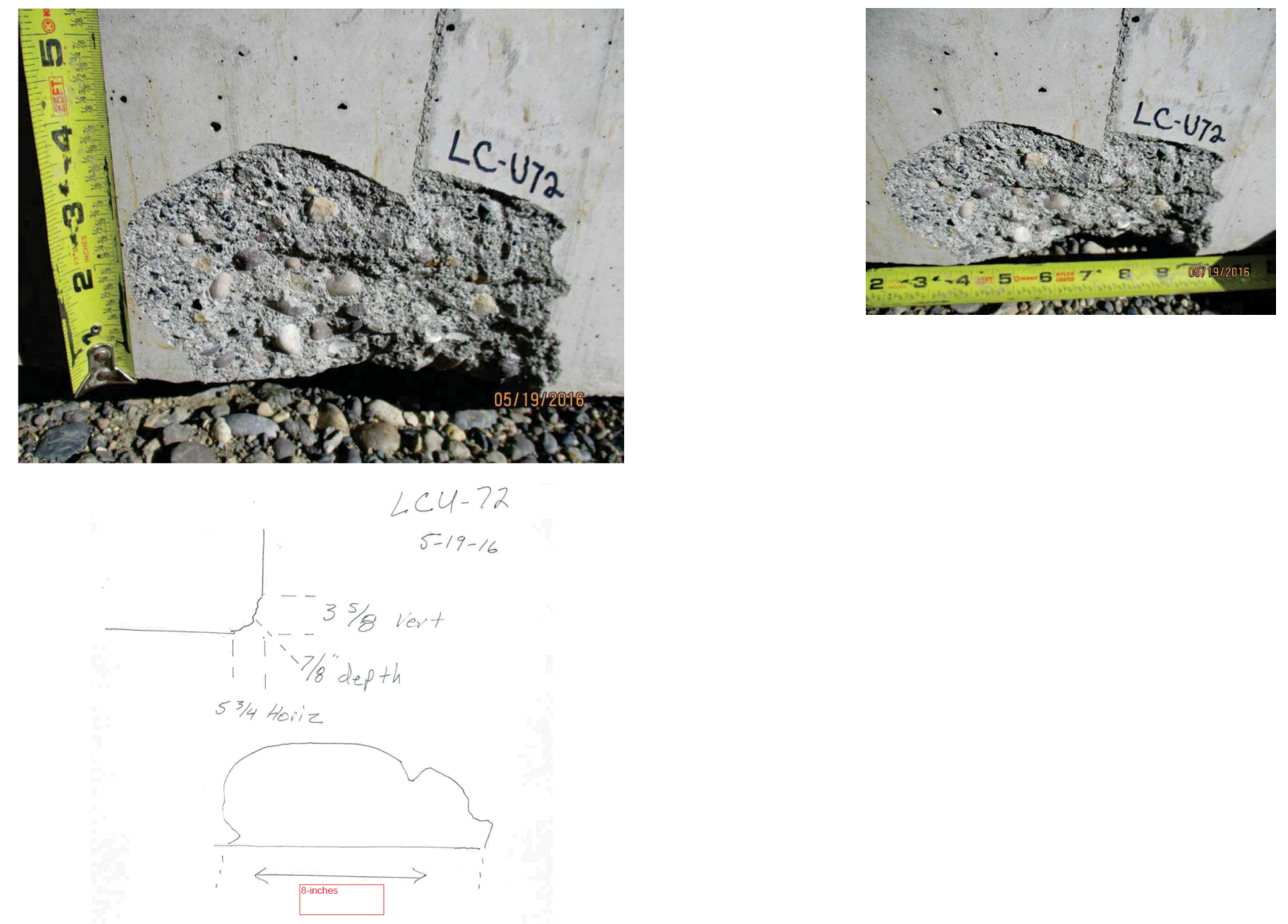

Figure 6. Diagram and photos showing the dimensions for damage during shipping for LCC vault riser LCU-72 from NCR-013. The damage relative to the component dimensions is quantified in Table 9 and is insignificant. 

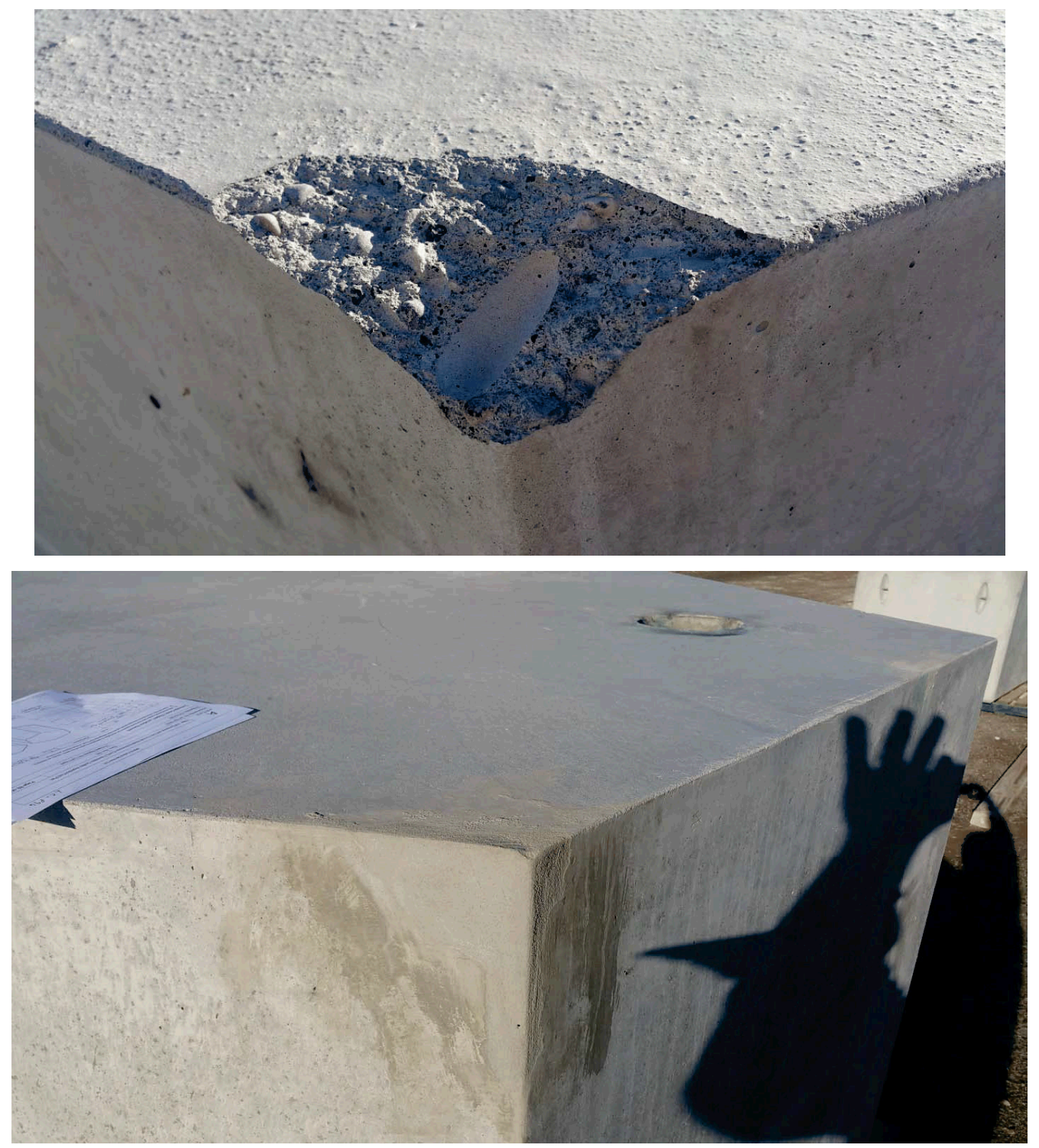

Figure 7. Example photograph of spalling on plug LC-P29 before and after repair from SNR-108. The damage relative to the component dimensions is quantified in Table 9 and is insignificant. 

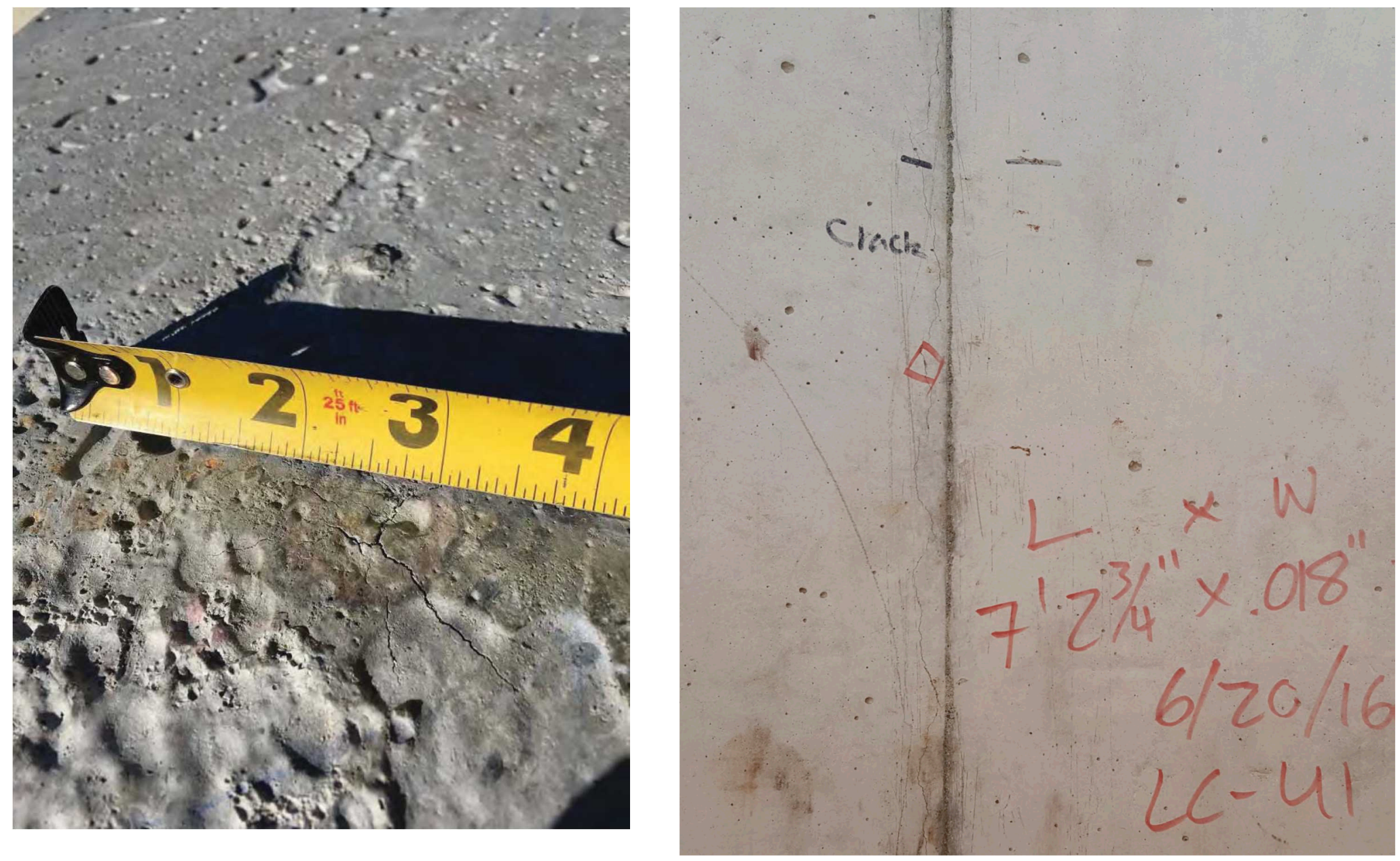

Figure 8. Level 3 crack with a width 0.03-in. on component HFEF-U5 from SNR-056 (left) and portion of crack in component LC-U1, exceeding 0.01-in. width from SNR-077. Note the widest cracks occur on the portion of the component not credited for durability; the longest crack parallels a seam in the concrete form. The damage relative to the component dimensions is quantified in Table 9 and is insignificant. 
Table 10. Summary of Level 3 concrete component defects and damage by component type and vault array.

\begin{tabular}{|c|c|c|c|c|c|c|c|c|c|}
\hline \multicolumn{10}{|c|}{ Vault Upper Riser Sections } \\
\hline & \multicolumn{3}{|c|}{ Component Data } & \multicolumn{3}{|c|}{ Summary Defect Data } & \multicolumn{3}{|c|}{ Defect Impact to Components in Array } \\
\hline Array & $\begin{array}{c}\text { Number } \\
\text { of Upper } \\
\text { Risers in } \\
\text { Array } \\
\end{array}$ & $\begin{array}{l}\text { Surface Area } \\
\text { of a Single } \\
\text { Upper Riser } \\
{\text { (in. }{ }^{2} \text { ) }}\end{array}$ & $\begin{array}{l}\text { Volume of a } \\
\text { Single } \\
\text { Upper Riser } \\
{\left.\text { (in. }{ }^{3}\right)}\end{array}$ & $\begin{array}{l}\text { Number of } \\
\text { Upper } \\
\text { Risers with } \\
\text { Defects } \\
\end{array}$ & $\begin{array}{l}\text { Defect Area } \\
\text { in Upper } \\
\text { Risers (in. }{ }^{2} \text { ) } \\
\end{array}$ & $\begin{array}{l}\text { Defect } \\
\text { Volume in } \\
\text { Upper } \\
\text { Risers (in. }{ }^{3} \text { ) } \\
\end{array}$ & $\begin{array}{l}\text { Percent of Upper } \\
\text { Risers with } \\
\text { Defects/Damage }\end{array}$ & $\begin{array}{c}\text { Percent of Total Upper } \\
\text { Riser Surface Area with } \\
\text { Defect/Damage in the } \\
\text { Array }\end{array}$ & $\begin{array}{c}\text { Percent of Total Upper } \\
\text { Riser Volume with } \\
\text { Defect/Damage in the } \\
\text { Array }\end{array}$ \\
\hline 55-Ton & 84 & 44,108 & 125,538 & 25 & 406 & 197 & 30 & 0.011 & $1.25 \mathrm{E}-06$ \\
\hline $\mathrm{LCC}^{\mathrm{a}}$ & 255 & 42,072 & 118,074 & 25 & 4,650 & 2,210 & 10 & 0.043 & $1.59 \mathrm{E}-05$ \\
\hline HFEF $^{\mathrm{a}}$ & 15 & 42,072 & 118,074 & 13 & 1,760 & 1,120 & 87 & 0.279 & 8.03E-06 \\
\hline $\mathrm{NuPac}$ & 60 & 52,590 & 147,592 & 36 & 2,900 & 1,390 & 60 & 0.092 & $6.38 \mathrm{E}-06$ \\
\hline FTC & 92 & 52,590 & 147,592 & 21 & 2,210 & 3,630 & 23 & 0.046 & $1.67 \mathrm{E}-05$ \\
\hline $\mathrm{PA}$ & 2 & 44,108 & 125,538 & 1 & 5.1 & 0.6 & 50 & 0.006 & $3.53 \mathrm{E}-09$ \\
\hline \multicolumn{10}{|c|}{ Vault Base Sections } \\
\hline Array & $\begin{array}{l}\text { Number } \\
\text { of Bases } \\
\text { in Array }\end{array}$ & $\begin{array}{l}\text { Surface Area } \\
\text { of a Single } \\
\text { Base Riser } \\
{\text { (in. }{ }^{2} \text { ) }}\end{array}$ & $\begin{array}{l}\text { Volume of a } \\
\text { Single Base } \\
\text { Riser (in. }{ }^{3} \text { ) }\end{array}$ & $\begin{array}{l}\text { Number of } \\
\text { Bases with } \\
\text { Defects }\end{array}$ & $\begin{array}{l}\text { Defect } \\
\text { Area in } \\
\text { Bases } \\
\text { (in. }{ }^{2} \text { ) }\end{array}$ & $\begin{array}{c}\text { Defect } \\
\text { Volume in } \\
\text { Bases (in. }{ }^{3} \text { ) }\end{array}$ & $\begin{array}{l}\text { Percent of Bases } \\
\text { with Defects/ } \\
\text { Damage }\end{array}$ & $\begin{array}{c}\text { Percent of Total Array } \\
\text { Base Riser Surface Area } \\
\text { with Defect/Damage }\end{array}$ & $\begin{array}{c}\text { Percent of Total Array } \\
\text { Base Riser Volume } \\
\text { with Defect/Damage }\end{array}$ \\
\hline 55-Ton & 84 & 44,108 & 125,538 & 30 & 541 & 220 & 36 & 0.015 & $1.40 \mathrm{E}-06$ \\
\hline $\mathrm{LCC}^{\mathrm{a}}$ & 255 & 42,072 & 118,074 & 54 & 1,020 & 785 & 21 & 0.010 & $5.63 \mathrm{E}-06$ \\
\hline $\mathrm{HFEF}^{\mathrm{a}}$ & 15 & 42,072 & 118,074 & 11 & 619 & 251 & 73 & 0.098 & $1.80 \mathrm{E}-06$ \\
\hline $\mathrm{NuPac}$ & 60 & 52,590 & 147,592 & 46 & 1,620 & 435 & 77 & 0.051 & $2.00 \mathrm{E}-06$ \\
\hline FTC & 92 & 52,590 & 147,592 & 10 & 695 & 1,020 & 11 & 0.014 & $4.68 \mathrm{E}-06$ \\
\hline $\mathrm{PA}$ & 2 & 44,108 & 125,538 & 2 & 28.3 & 7.4 & 100 & 0.032 & $4.66 \mathrm{E}-08$ \\
\hline \multicolumn{10}{|c|}{ Vault Shield Plugs } \\
\hline Array & $\begin{array}{l}\text { Number } \\
\text { of Plugs } \\
\text { in Array }\end{array}$ & $\begin{array}{l}\text { Surface Area } \\
\text { of a Single } \\
\text { Plug (in. }{ }^{2} \text { ) } \\
\end{array}$ & $\begin{array}{l}\text { Volume of a } \\
\text { Single Plug } \\
{\text { (in. }{ }^{3} \text { ) }}\end{array}$ & $\begin{array}{l}\text { Number of } \\
\text { Plugs with } \\
\text { Defects } \\
\end{array}$ & $\begin{array}{c}\text { Defect } \\
\text { Area in } \\
\text { Plugs (in. }{ }^{2} \text { ) } \\
\end{array}$ & $\begin{array}{c}\text { Defect } \\
\text { Volume in } \\
\text { Plugs (in. }{ }^{3} \text { ) } \\
\end{array}$ & $\begin{array}{l}\text { Percent of Plugs } \\
\text { with Defects/ } \\
\text { Damage } \\
\end{array}$ & $\begin{array}{l}\text { Percent of Total Vault } \\
\text { Array Plug Surface Area } \\
\text { with Defect/Damage }\end{array}$ & $\begin{array}{l}\text { Percent of Total Array } \\
\text { Plug Volume with } \\
\text { Defect/Damage }\end{array}$ \\
\hline 55-Ton & 84 & 22,364 & 244,518 & 20 & 548 & 151 & 24 & 0.029 & $2.53 \mathrm{E}-07$ \\
\hline $\mathrm{LCC}^{\mathrm{a}}$ & 255 & 28,005 & 340,657 & 31 & 1,470 & 1,250 & 12 & 0.021 & $1.08 \mathrm{E}-06$ \\
\hline HFEF $^{\mathrm{a}}$ & 15 & 28,005 & 340,657 & 7 & 624 & 761 & 47 & 0.149 & $6.56 \mathrm{E}-07$ \\
\hline $\mathrm{NuPac}$ & 60 & 35,951 & 479,995 & 38 & 2,210 & 1,050 & 63 & 0.102 & $4.56 \mathrm{E}-07$ \\
\hline FTC & 92 & 35,951 & 479,995 & 21 & 797 & 862 & 23 & 0.024 & $3.74 \mathrm{E}-07$ \\
\hline PA & 2 & 22,364 & 244,518 & 3 & 58.9 & 16.4 & 150 & 0.132 & $2.74 \mathrm{E}-08$ \\
\hline
\end{tabular}

a HFEF and LCC vaults are located in the same array. 


\subsubsection{Physical Investigation and Repair of Vault Component Cracks}

Cracking exceeding the 0.01-in. width limit imposed by PLN-5460 and PLN-5077 was more frequently observed in the more massive concrete components (such as the vault plugs and interior void partition areas of the HFEF and FTC upper risers and bases) as indicated in Table 9. In some of these components, the width of the crack apparently increased from the time of initial inspection to the time of installation, which in some cases was several months, or were discovered during installation (i.e., see NCR-29). This phenomenon is explained in the attachment found in Appendix A. Simply, as reinforced concrete cures and hydrates, there is an enormous amount of heat generated that results in thermal expansion and contraction of the concrete components during the months-long curing process. In addition, there are local temperature changes that affect the surface temperature of the more massive components requiring very long time periods to cure. Per the Portland Cement Association Design and Control of Concrete Mixtures:

"As the interior concrete increases in temperature and expands, the surface concrete may be cooling and contracting. This causes tensile stresses that may result in thermal cracks at the surface if the temperature differential between the surface and center is too great. The width and depth of cracks depends upon the temperature differential, physical properties of the concrete, and the reinforcing steel."

Therefore, for the more massive components, surface cracking and increase over time of crack widths is expected.

In standard practice, the depth of cracking is controlled by the depth of concrete covering the steel-reinforcing materials. Based on requirements of the RH-LLW Disposal Facility project, at least 2-in. of concrete cover was required for the plugs and riser sections, and prior to pouring the concrete, the rebar depth was inspected and verified to meet the requirements. The temperature environment was controlled during initial component curing and the physical properties of the concrete include high compressive (and, therefore, tensile) strength. The concrete mix design, pouring, and curing process limited cracking to very few components (as noted in Table 9).

Crack widths smaller than 0.01-in. are allowable in these inspection plans based on their potential to heal autogenously as discussed in Section 4.2. Potentially non-healing cracks (i.e., those exceeding the 0.01-in. width limit imposed by the project) were evaluated further based on the relative importance of concrete cracking to concrete strength and durability. In this evaluation, physical crack depths were investigated as reported in SNR-086, SNR-124, and SNR-45 with a letter of explanation provided as Appendix A. These investigations show that the depth of shrinkage cracks exceeding the 0.01 -in. Level 3 crack width limit ranged from 3/8 to 5/8-in. for representative cracks in plug NP-P7 (see SNR-087), 0.448-in. for the longer 47-in. crack found in plug LC-P95 (see SNR-124), and 1/32-in. for the 48-in. long crack found in upper riser NP-U19. From these investigations, the maximum crack depth associated with shrinkage cracks in these reinforced concrete components are roughly equivalent to the $1 / 2$-in. concrete loss allowable for honeycombing, bugholes, and spalling.

Cracks widths 0.01 -in. or larger were repaired by the RH-LLW Disposal Facility project. Cracks were repaired in order to prevent water from entering them and possibly leading to premature component degradation over time. Repairs were made regardless of whether the components were installed above the freeze/thaw depth or below that depth. This determination was made in order to protect shield plugs installed above the freeze/thaw line that could be more susceptible to freeze/thaw expansion cracking and to protect the steel reinforcement from premature corrosion for components installed deeper. 


\section{CONCRETE TEST DATA AND ANALYSIS}

The facility performance specification (SPC-1437) required the design-build contractor to provide the vault system concrete mix design and cured cylinder test plans and results. Concrete data resulting from specified analyses were recorded in either PLN-5077 or PLN-5460. Completed records are maintained in the INL Vendor Data System under Project 31055. Including specific requirements of SPC-1437, the following tests or data were specified in the Vault Concrete Compliance Test Plan (PLN-4956):

- Chemical Composition. These requirements were fulfilled through submittal of the Vault Concrete Mix Design Report (PLN-4953) and strict adherence to the concrete mix through vault fabrication as documented in the Vault Component and Cask-To-Vault Adapting Structures (CVAS) Fabrication Quality Inspection/Test Plan (PLN-5460 or PLN-5077) reports for each component produced at Oldcastle.

- Temperature, Unit Weight, and Yield of Fresh Concrete Samples. The minimum air-dried unit weight (density) was required to show compliance with the minimum $134 \mathrm{lb} / \mathrm{ft}^{3}$ determined by the Vault Plug Shielding Analysis (ECAR+2747). Temperature was required for conformance to curing limitations and yield was recorded for completeness. Concrete samples were tested for density and yield in accordance with ASTM C138. Concrete samples were tested for temperature in accordance with ASTM C1064.

- Air Content. Two separate mix designs were used in fabricating the vault components as discussed in Section 3.2. Mix \#2 contained an air-entraining admixture to provide freeze protection for the shield plugs and perimeter pieces installed above the frost line. Mix \#3 did not contain an air-entraining admixture and was used for the vault upper risers and base sections because they were installed below the frost line. Tests were performed on fresh concrete samples in accordance with ASTM C231.

- Porosity. These requirements were fulfilled in accordance with the requirements of PLN-4956. In addition to porosity, density and absorption were provided. Porosity tests were performed on six random, hardened Mix \#3 (i.e., the concrete mix used for the base and upper riser components installed below the frost line) concrete samples from each vault array (i.e., four arrays total) for a total of 24 samples. The tests were conducted to determine density, percent absorption, and percent voids in accordance with ASTM C642. Test data were collected on three of the samples at an age of 28 days and on the other three samples at an age of 90 days by Certified Testing Laboratories Inc.

- Permeability/Hydraulic Conductivity. These requirements were fulfilled in accordance with the requirements of PLN-4956. The permeability tests were performed on six random Mix \#3 hardened concrete samples from each vault array (i.e., four total) for a total of 24 samples. The permeability was measured in accordance with American Petroleum Institute (API) RP 40, "Recommended Practices for Core Analysis," at the Terra-Tek laboratories in Salt Lake City, Utah.

- Diffusivity (Chloride). Attachment 5 of PLN-4952 contains the chloride diffusivity results obtained during the concrete mix design process for both Mix \#3 and Mix \#2.

- Water Soluble Chloride Content. The water-soluble chloride ion content was tested to verify consistency with mix design testing according to ASTM C1218. The maximum water-soluble chloride ion content in concrete percent by weight was specified to be $0.15 \%$.

- Compressive Strength. Concrete samples for strength tests were cured in accordance with

ASTM C31, with testing performed in compliance with ASTM C39. Tests were performed at 7 days, 14 days, and 28 days. The minimum acceptable 28-day compressive strength specified by SPC-1437 was 5,000 psi. 


\subsection{Concrete Density, Absorption, and Porosity Data}

Concrete density, absorption, and porosity were obtained for six hardened concrete samples taken from each of the four vault arrays destined to receive LLW. Data were collected according to ASTM C642. This test method provides the following:

- Oven Dried Sample Mass. Determined by placing the specimen in a forced draft oven and drying the sample at a temperature of $230 \pm 9^{\circ} \mathrm{F}\left(110 \pm 5^{\circ} \mathrm{C}\right)$ for no less than 24 hours, cooling in dry air to a temperature of $72 \pm 5^{\circ} \mathrm{F}\left(22 \pm 3^{\circ} \mathrm{C}\right)$, and determining the mass. If the specimen was comparatively dry when its mass was first determined and the second mass agrees with the first within $0.5 \%$, consider it dry; otherwise, repeat the drying step. If the difference between values obtained from two successive values of mass exceeds $0.5 \%$ of the lesser value, return the specimens to the oven for an additional 24-hour drying period and repeat the procedure until the difference between any two successive values is less than $0.5 \%$ of the lowest value obtained. Designate this last value to be the oven dry sample mass, which is designated value A.

- Surface Dry Mass in Air after Immersion. Determined by immersing the specimen on its edge in water at $72 \pm 5^{\circ} \mathrm{F}\left(22 \pm 3^{\circ} \mathrm{C}\right)$ and soaking the specimen in water for no less than 48 hours and until two successive mass values for the surface-dried sample at intervals of 24 hours show an increase in mass less than $0.5 \%$ of the larger value. Then the surface moisture is removed using a towel and the immersed surface mass is obtained, which is designated value $\mathrm{B}$.

- Surface Dry Mass in Water after Immersion and Boiling. Determined by first placing the specimen in boiling water for at least 5 hours, followed by cooling through natural loss of heat for no less than 14 hours to a final temperature of $72 \pm 5^{\circ} \mathrm{F}\left(22 \pm 3^{\circ} \mathrm{C}\right)$. After these steps, the sample is suspended in water and weighed, which is designated value $\mathrm{D}$.

- Surface Dry Mass in Air after Immersion and Boiling. Determined by first placing the specimen in boiling water for at least 5 hours, followed by cooling through natural loss of heat for no less than 14 hours to a final temperature of $72 \pm 5^{\circ} \mathrm{F}\left(22 \pm 3^{\circ} \mathrm{C}\right)$. After these steps, the sample is dried and weighed, which is designated value $\mathrm{C}$.

- Absorption after immersion: Absorption $_{i} \%=\left[\frac{B-A}{A}\right] \times 100$

- Absorption after immersion and boiling: Absorption $_{i b} \%=\left[\frac{C-A}{A}\right] \times 100$

- Bulk density, dry: $\rho_{\text {bulk }}=\left[\frac{A}{C-D}\right] \times \rho_{\text {water }} \times 100$

- Bulk density after immersion: $\rho_{i}=\left[\frac{B}{C-D}\right] \times \rho_{\text {water }}$

- Bulk density after immersion and boiling: $\rho_{i b}=\left[\frac{C}{C-D}\right] \times \rho_{\text {water }}$

- Apparent density: $\rho_{A}=\left[\frac{A}{A-D}\right] \times \rho_{\text {water }}$

- Volume of permeable pore space (voids) = total porosity:

$$
\phi_{\text {total }} \%=\left(\rho_{A}-\rho_{\text {bulk }}\right) / \rho_{A} \times 100=[(\mathrm{C}-\mathrm{A}) /(\mathrm{C}-\mathrm{D})] \times 100
$$

where:

$\phi_{\text {total }}=$ total porosity

$\mathrm{A}=$ mass of oven-dried sample in air

$\mathrm{B}=$ mass of surface-dry sample in air after immersion 
$\mathrm{C}=$ mass of surface-dry sample in air after immersion and boiling

$\mathrm{D}=$ apparent mass of sample in water after immersion and boiling

$\rho_{\text {bulk }}=$ bulk density, dry

$\rho_{\mathrm{A}}=$ apparent density

$\rho_{\text {water }}=$ density of water.

Resulting data are given in Table 11 for concrete samples held for either 28 or 90 days. In Table 11, there are two samples with results for hold times at 34 and 40 days. The difference in hold time was an error by the design-build subcontractor and data are provided for information.

Data important to concrete performance include the following:

- Total Porosity. This is important to concrete durability because it can influence the penetration time for water and air to reach the steel reinforcement although the effective porosity is a more representative value to use to describe this process. The average value for total porosity was determined to be $14.3 \%$, with a standard deviation of $1.2 \%$ and coefficient of variation of $8.7 \%$. The porosity data are shown in Figure 9 as a function of time the test cylinder concrete was held after pouring the test cylinders prior to conducting the porosity test (i.e., the hold time). This figure shows the variability in porosity decreases with increasing hold times, with the average value equal to $14.3 \%$, the standard deviation equal to $0.7 \%$, and the coefficient of variation equal to $4.7 \%$ for longer hold times. This trend is typical of test data for concrete with a smaller porosity and coefficient of variation occurring as the concrete continues to cure.

- Bulk Density. This is important to the shielding function of the upper portion of the vault risers. The data shown in this table were not obtained for the shield plugs. Bulk density as reported using the methods in ASTM C642 represents a completely dry environment because the data are obtained after oven drying the samples. The average value for bulk density was determined to be $134 \mathrm{lb} / \mathrm{ft}^{3}$, with a standard deviation of $3 \mathrm{lb} / \mathrm{ft}^{3}$ and coefficient of variation of $2 \%$.

For both data sets, the low coefficients of variation provide an indication that concrete components are uniform and exhibit little overall variability.

Table13 provides the statistical correlation between total porosity and other measured parameters obtained using the ASTM C642 methods. The P-value less than 0.15 for dry bulk density, wet density, apparent density, and wet absorption indicates a relatively high degree of correlation for these parameters to total porosity. As substantiated by the similarity in average value and standard deviation, total porosity is less strongly correlated to the number of days the samples were held prior to taking the test data.

Table 14 provides concrete batch ticket (i.e., mix ticket) data for each of the tested samples. This table contains the amount of aggregate (i.e., gravel and sand) added to the cement, the pozzolan (i.e., flyash) amounts, and the water/cement ratio given in Column 8. The amounts of admixtures used in each of the tested concrete batches are provided in Columns 9 through 11. Summary statistics for concrete components indicate the water/cement ratio is within specifications and the highest variability in concrete component quantities occurs with the accelerator with a coefficient of variation equal to $14 \%$. Variability in water added is accounted for in the water/cement ratio, which accounts for moisture content of the aggregate.

The variation in porosity could partially be accounted for by variation in the NC534 accelerator shown by the low P-value in Table 14. However, there is little correlation with porosity and water/cement ratio or with the Glenium superplasticizer. 
Table 11. Concrete density, absorption, and porosity data.

\begin{tabular}{|c|c|c|c|c|c|c|c|c|c|c|c|c|c|c|c|}
\hline \multirow[b]{2}{*}{$\begin{array}{c}\text { Sample } \\
\text { Name }\end{array}$} & \multirow[b]{2}{*}{$\begin{array}{c}\text { Batch } \\
\text { ID }\end{array}$} & \multicolumn{3}{|c|}{ Dates (2016) } & \multicolumn{4}{|c|}{ Mass (g) } & \multicolumn{4}{|c|}{ Density $\left(\mathbf{l b} / \mathbf{f t}^{\mathbf{3}}\right)$} & \multicolumn{2}{|c|}{$\begin{array}{c}\text { Absorption } \\
\% \\
\end{array}$} & \multirow[b]{2}{*}{$\begin{array}{c}\text { Total } \\
\text { Porosity } \\
\% \\
\left(\phi_{\text {total }}\right) \\
\end{array}$} \\
\hline & & $\begin{array}{c}\text { Poure } \\
\text { d }\end{array}$ & $\begin{array}{c}\text { Teste } \\
\text { d }\end{array}$ & $\begin{array}{c}\text { Held } \\
\text { Day } \\
\text { s } \\
\end{array}$ & $\begin{array}{c}\text { Oven } \\
\text { Dry }\end{array}$ & $\begin{array}{c}\text { Surface } \\
\text { Dry } \\
\text { in Air after } \\
\text { Immersion } \\
\end{array}$ & $\begin{array}{c}\text { Surface } \\
\text { Dry } \\
\text { in Air after } \\
\text { Immersion } \\
\text { and Boiling }\end{array}$ & $\begin{array}{c}\text { Apparent } \\
\text { in Water } \\
\text { after } \\
\text { Immersion } \\
\text { and Boiling }\end{array}$ & $\begin{array}{c}\text { Dry } \\
\text { Bulk } \\
\left(\rho_{\text {bulk }}\right. \\
\quad) \\
\end{array}$ & $\begin{array}{c}\text { After } \\
\text { Immersio } \\
\text { n }\end{array}$ & $\begin{array}{c}\text { After } \\
\text { Immersio } \\
\mathbf{n} \\
\text { and } \\
\text { Boiling } \\
\end{array}$ & $\begin{array}{c}\text { Apparen } \\
\mathbf{t} \\
\left(\rho_{A}\right) \\
\end{array}$ & Dry & Wet & \\
\hline PorNuPac1 & 51958 & $2 / 9$ & $3 / 14$ & 34 & 1,134 & $1,188.5$ & $1,188.4$ & 676.4 & 137.9 & 144.8 & 144.8 & 154.8 & 4.8 & 4.8 & 10.9 \\
\hline PorNuPac3 & 52148 & $2 / 19$ & $3 / 18$ & 28 & $\begin{array}{c}1,019 . \\
2\end{array}$ & $1,099.5$ & $1,102.6$ & 600.8 & 126.7 & 136.7 & 137.3 & 152.3 & 7.9 & 8.2 & 16.8 \\
\hline PorNuPac4 & 52148 & $2 / 19$ & $5 / 19$ & 90 & $\begin{array}{c}1,094 . \\
1 \\
\end{array}$ & $1,165.3$ & $1,165.1$ & 654.9 & 133.5 & 142.3 & 142.3 & 155.4 & 6.5 & 6.5 & 14.1 \\
\hline PorNuPac5 & 52948 & $3 / 23$ & $6 / 21$ & 90 & $\begin{array}{c}1,320 . \\
5\end{array}$ & $1,412.3$ & $1,411.2$ & 790.4 & 132.9 & 141.6 & 141.6 & 155.4 & 7 & 6.9 & 14.5 \\
\hline $\begin{array}{l}\text { Por- } \\
\text { HFEF/LCC- } \\
1\end{array}$ & 53374 & $4 / 5$ & $5 / 3$ & 28 & $\begin{array}{c}1,128 . \\
4\end{array}$ & $1,206.9$ & $1,207.5$ & 676.7 & 132.9 & 141.6 & 141.6 & 156 & 7 & 7 & 14.8 \\
\hline $\begin{array}{l}\text { Por - } \\
\text { HFEF/LCC- } \\
2\end{array}$ & 53441 & $4 / 7 /$ & $7 / 6$ & 90 & 1,337 & $1,418.4$ & $1,421.5$ & 808.3 & 136 & 144.1 & 144.8 & 157.9 & 6.1 & 6.3 & 13.8 \\
\hline $\begin{array}{l}\text { Por - } \\
\text { HFEF/LCC- } \\
3\end{array}$ & 53572 & $4 / 12$ & $5 / 10$ & 28 & $\begin{array}{c}1,103 . \\
2\end{array}$ & $1,183.5$ & $1,183.2$ & 659.3 & 131.7 & 141 & 141 & 155.4 & 7.3 & 7.2 & 15.3 \\
\hline $\begin{array}{l}\text { Por- } \\
\text { HFEF/LCC- } \\
4\end{array}$ & 55073 & $5 / 24$ & $8 / 22$ & 90 & $\begin{array}{c}1,120 . \\
5\end{array}$ & $1,189.7$ & $1,189.8$ & 674.3 & 135.4 & 144.1 & 144.1 & 156.6 & 6.2 & 6.2 & 13.5 \\
\hline $\begin{array}{l}\text { Por- } \\
\text { HFEF/LCC- } \\
5\end{array}$ & 56103 & $6 / 22 /$ & $9 / 20$ & 90 & 1,106 & $1,177.6$ & $1,180.6$ & 669.4 & 134.8 & 143.5 & 144.1 & 157.9 & 6.5 & 6.7 & 14.6 \\
\hline $\begin{array}{l}\text { Por- } \\
\text { HFEF/LCC- } \\
6\end{array}$ & 56430 & $7 / 1$ & $8 / 3$ & 28 & 1,347 & 1,437 & $1,440.9$ & 614.3 & 134.2 & 142.9 & 143.5 & 157.9 & 6.7 & 7 & 15 \\
\hline Por-55T-1 & 53408 & $4 / 6$ & $5 / 4$ & 28 & $\begin{array}{c}1,135 . \\
4\end{array}$ & $1,200.5$ & $1,199.8$ & 685.5 & 137.9 & 145.4 & 145.4 & 157.2 & 5.7 & 5.7 & 12.3 \\
\hline Por-55T-2 & 53485 & $4 / 8$ & $7 / 7$ & 90 & $\begin{array}{c}1,353 \\
3 \\
\end{array}$ & $1,438.7$ & $1,441.7$ & 814.6 & 134.8 & 142.9 & 143.5 & 156.6 & 6.3 & 6.5 & 13.9 \\
\hline Por-55T-3 & 54115 & $4 / 27$ & $7 / 26$ & 90 & $\begin{array}{c}1,339 . \\
1\end{array}$ & $1,422.6$ & $1,422.8$ & 803.9 & 134.8 & 143.5 & 143.5 & 156 & 6.2 & 6.3 & 13.6 \\
\hline
\end{tabular}


Table 11. (continued).

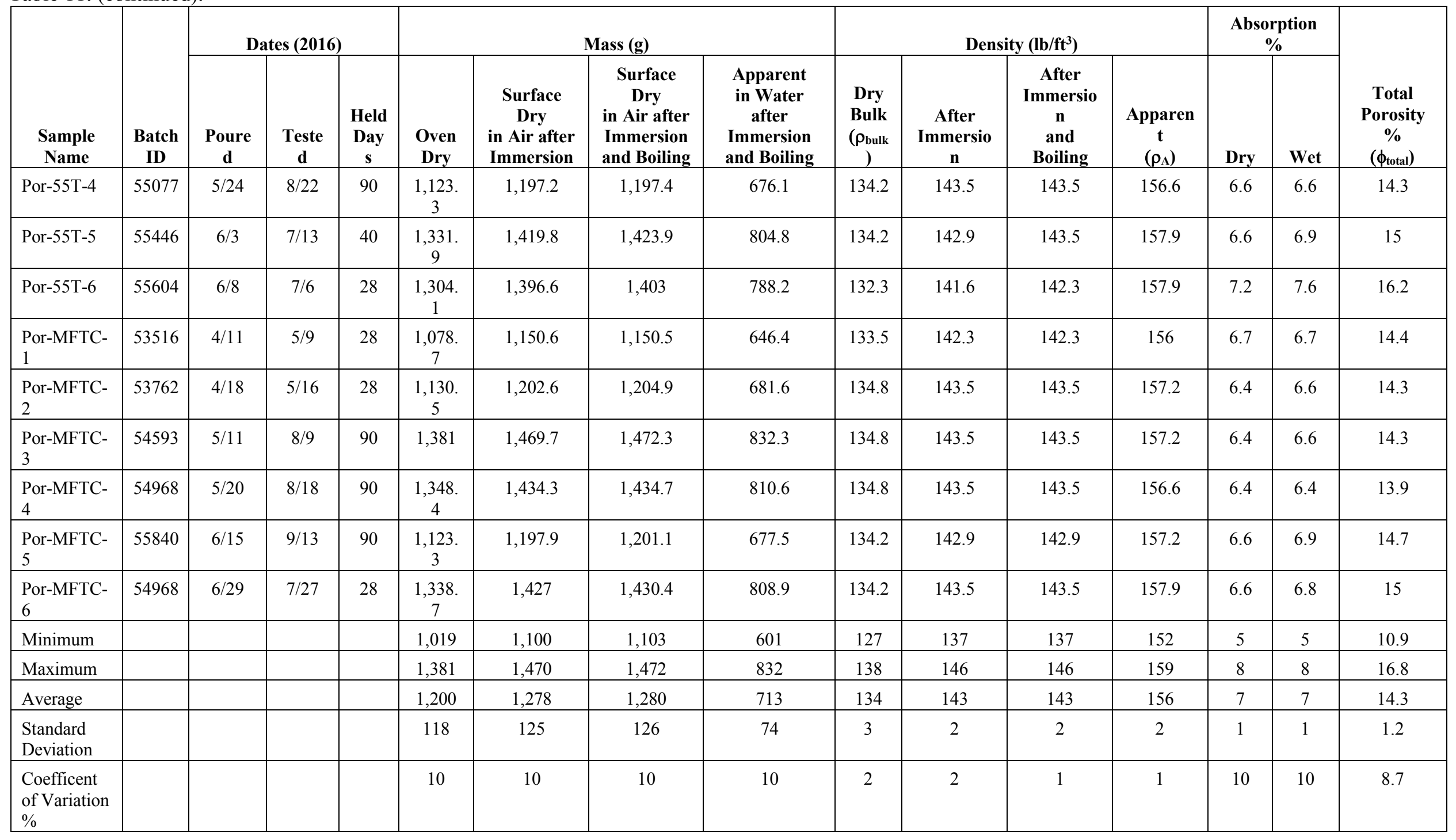




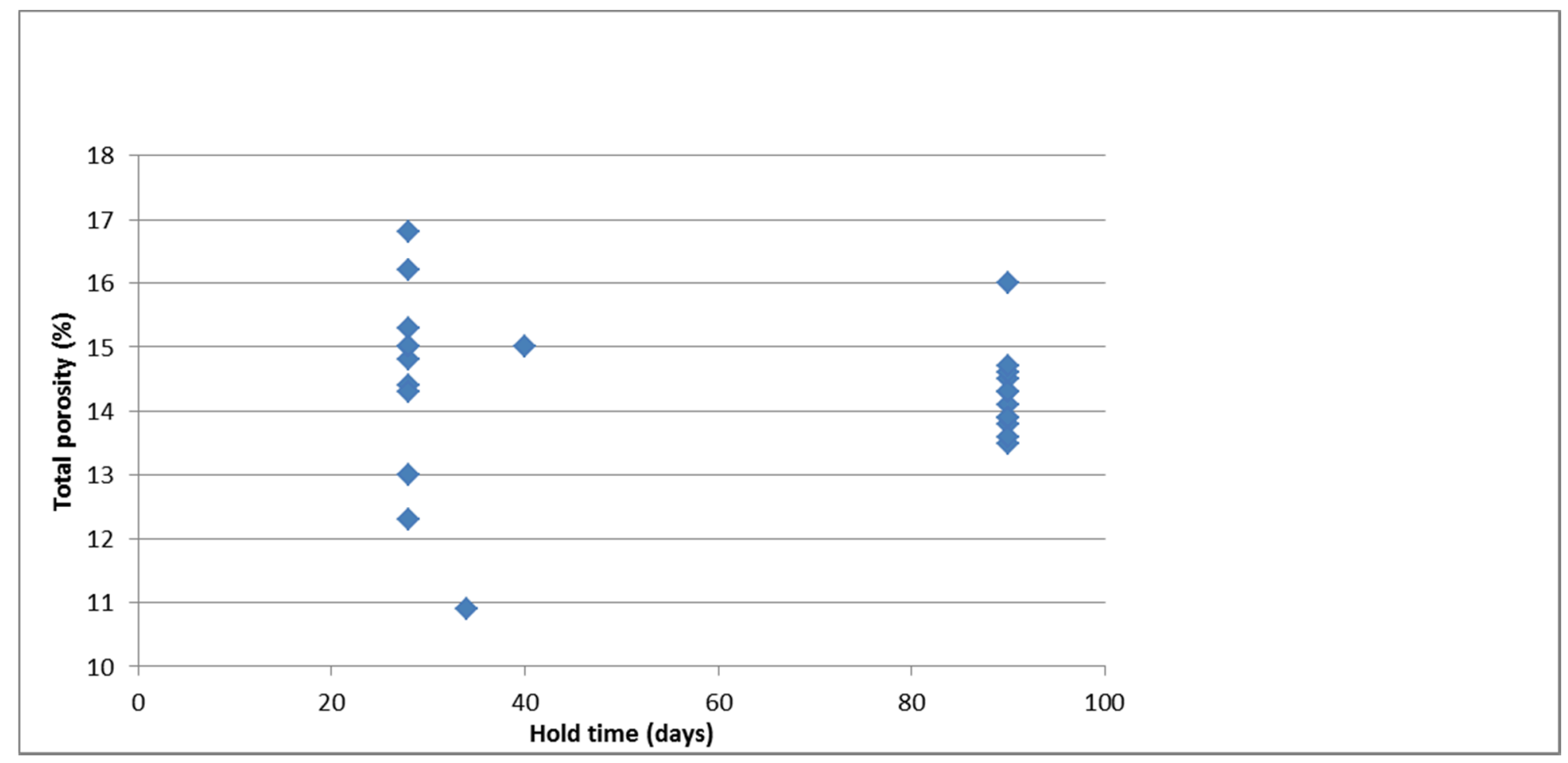

Figure 9. Total porosity as a function of hardened concrete hold time prior to testing. 
Table 12. Correlation between total porosity and other measured values from ASTM C642 data.

\begin{tabular}{lr}
\hline \multicolumn{2}{c}{ Regression Statistics } \\
\hline Multiple R & 0.9999 \\
R Square & 0.9998 \\
Adjusted R Square & 0.9996 \\
Standard Error & 0.0247 \\
Observations & 24 \\
\hline
\end{tabular}

\begin{tabular}{lccccc} 
ANOVA & & & & & \\
& df & SS & MS & F & Significance \\
\hline Regression & 11 & $3.47 \mathrm{E}+01$ & $3.16 \mathrm{E}+00$ & $5.17 \mathrm{E}+0$ & $2.78 \mathrm{E}-20$ \\
& & & & 3 & \\
Residual & 11 & $7.32 \mathrm{E}-03$ & $6.10 \mathrm{E}-04$ & & \\
Total & 22 & $3.47 \mathrm{E}+01$ & & & \\
\hline
\end{tabular}

\begin{tabular}{|c|c|c|c|c|c|c|c|c|}
\hline & $\begin{array}{c}\text { Coefficient } \\
\text { s }\end{array}$ & $\begin{array}{c}\text { Standard } \\
\text { Error }\end{array}$ & t Stat & P-value & Lower $95 \%$ & Upper $95 \%$ & $\begin{array}{l}\text { Lower } \\
95.0 \%\end{array}$ & $\begin{array}{l}\text { Upper } \\
95.0 \%\end{array}$ \\
\hline Intercept & $1.32 \mathrm{E}+01$ & $1.78 \mathrm{E}+00$ & $7.40 \mathrm{E}+00$ & $8.23 \mathrm{E}-06$ & $9.30 \mathrm{E}+00$ & $1.71 \mathrm{E}+01$ & $9.30 \mathrm{E}+00$ & $1.71 \mathrm{E}+01$ \\
\hline Held days & $-6.49 \mathrm{E}-05$ & $2.20 \mathrm{E}-04$ & $-2.96 \mathrm{E}-01$ & 7.73E-01 & $-5.43 \mathrm{E}-04$ & 4.14E-04 & $-5.43 \mathrm{E}-04$ & 4.14E-04 \\
\hline Oven dry mass & $-1.71 \mathrm{E}-02$ & $1.64 \mathrm{E}-02$ & $-1.04 \mathrm{E}+00$ & $3.18 \mathrm{E}-01$ & $-5.28 \mathrm{E}-02$ & $1.87 \mathrm{E}-02$ & $-5.28 \mathrm{E}-02$ & $1.87 \mathrm{E}-02$ \\
\hline Surface dry mass in air after immersion & $1.92 \mathrm{E}-02$ & $2.31 \mathrm{E}-02$ & $8.32 \mathrm{E}-01$ & 4.22E-01 & $-3.10 \mathrm{E}-02$ & $6.94 \mathrm{E}-02$ & $-3.10 \mathrm{E}-02$ & $6.94 \mathrm{E}-02$ \\
\hline Surface dry mass in air after immersion and boiling & $-3.21 \mathrm{E}-03$ & $1.81 \mathrm{E}-02$ & $-1.78 \mathrm{E}-01$ & $8.62 \mathrm{E}-01$ & $-4.26 \mathrm{E}-02$ & $3.62 \mathrm{E}-02$ & $-4.26 \mathrm{E}-02$ & $3.62 \mathrm{E}-02$ \\
\hline $\begin{array}{l}\text { Apparent mass in water after immersion and } \\
\text { boiling }\end{array}$ & $8.88 \mathrm{E}-05$ & $1.57 \mathrm{E}-04$ & $5.67 \mathrm{E}-01$ & $5.81 \mathrm{E}-01$ & $-2.52 \mathrm{E}-04$ & $4.30 \mathrm{E}-04$ & $-2.52 \mathrm{E}-04$ & $4.30 \mathrm{E}-04$ \\
\hline Dry bulk density ( $\rho$ bulk) & $-5.74 \mathrm{E}-01$ & $2.89 \mathrm{E}-02$ & $-1.98 \mathrm{E}+01$ & $1.55 \mathrm{E}-10$ & $-6.37 \mathrm{E}-01$ & $-5.11 \mathrm{E}-01$ & $-6.37 \mathrm{E}-01$ & $-5.11 \mathrm{E}-01$ \\
\hline Wet density $\left(\rho_{\text {wet }}\right)$ & 8.37E-02 & $3.56 \mathrm{E}-02$ & $2.35 \mathrm{E}+00$ & $3.65 \mathrm{E}-02$ & $6.18 \mathrm{E}-03$ & $1.61 \mathrm{E}-01$ & $6.18 \mathrm{E}-03$ & $1.61 \mathrm{E}-01$ \\
\hline Wet density after immersion and boiling & $-6.60 \mathrm{E}-02$ & 4.10E-02 & $-1.61 \mathrm{E}+00$ & $1.34 \mathrm{E}-01$ & $-1.55 \mathrm{E}-01$ & $2.34 \mathrm{E}-02$ & $-1.55 \mathrm{E}-01$ & 2.34E-02 \\
\hline Apparent density $\left(\rho_{\mathrm{A}}\right)$ & $4.80 \mathrm{E}-01$ & $3.75 \mathrm{E}-02$ & $1.28 \mathrm{E}+01$ & $2.37 \mathrm{E}-08$ & $3.98 \mathrm{E}-01$ & $5.62 \mathrm{E}-01$ & $3.98 \mathrm{E}-01$ & $5.62 \mathrm{E}-01$ \\
\hline Dry absorption & $-3.31 \mathrm{E}-01$ & $2.41 \mathrm{E}-01$ & $-1.37 \mathrm{E}+00$ & $1.94 \mathrm{E}-01$ & $-8.55 \mathrm{E}-01$ & $1.94 \mathrm{E}-01$ & $-8.55 \mathrm{E}-01$ & $1.94 \mathrm{E}-01$ \\
\hline Wet absorption & $3.98 \mathrm{E}-01$ & $1.49 \mathrm{E}-01$ & $2.67 \mathrm{E}+00$ & $2.03 \mathrm{E}-02$ & $7.36 \mathrm{E}-02$ & 7.23E-01 & $7.36 \mathrm{E}-02$ & 7.23E-01 \\
\hline
\end{tabular}


Table 13. Concrete porosity and density versus batch ticket data.

\begin{tabular}{|c|c|c|c|c|c|c|c|c|c|c|}
\hline Sample Name & $\begin{array}{c}\text { Cement } \\
\text { (lb) }\end{array}$ & $\begin{array}{c}\text { Flyash } \\
\text { (lb) }\end{array}$ & $\begin{array}{c}\text { Gravel } \\
\text { (lb) }\end{array}$ & $\begin{array}{c}\text { Sand } \\
(\mathbf{l b})\end{array}$ & $\begin{array}{c}\text { Water } \\
\text { (gal) }\end{array}$ & $\begin{array}{l}\text { Prewater } \\
\text { (gal) }\end{array}$ & $\begin{array}{c}\text { Water/Cement } \\
\text { Ratio (w/cm) } \\
\end{array}$ & $\begin{array}{c}\text { Glenium (oz) } \\
\text { Superplasticizer }\end{array}$ & $\begin{array}{l}\text { NC534 (oz) } \\
\text { Accelerator }\end{array}$ & $\begin{array}{c}\text { ASR } 30(0 z) \\
\text { Lithium } \\
\end{array}$ \\
\hline PorNuPac1 & 1,162 & 320 & 2,870 & 2,770 & 32.8 & 24.8 & 0.3700 & 45 & 440 & 488 \\
\hline PorNuPac2 & 1,162 & 320 & 2,870 & 2,770 & 32.8 & 24.8 & 0.3700 & 45 & 440 & 488 \\
\hline PorNuPac3 & 1,162 & 320 & 2,780 & 2,830 & 45.8 & 24.3 & 0.3700 & 50 & 360 & 488 \\
\hline PorNuPac4 & 1,162 & 320 & 2,780 & 2,830 & 45.8 & 24.3 & 0.3700 & 50 & 360 & 488 \\
\hline PorNuPac5 & 1,160 & 320 & 2,810 & 2,785 & 37 & 24.3 & 0.3720 & 45 & 398 & 488 \\
\hline PorNuPac6 & 1,158 & 320 & 2,790 & 2,850 & 39.5 & 24.5 & 0.3710 & 45 & 400 & 488 \\
\hline Por-HFEF/LCC-1 & 1,164 & 320 & 2,800 & 2,920 & 34.3 & 24.5 & 0.3700 & 400 & 488 & 1,164 \\
\hline Por -HFEF/LCC-2 & 1,158 & 320 & 2,785 & 2,825 & 45.3 & 24.5 & 0.3740 & 300 & 488 & 1,158 \\
\hline Por -HFEF/LCC-3 & 1,160 & 320 & 2,790 & 2,790 & 43.8 & 24.3 & 0.3710 & 400 & 488 & 1,160 \\
\hline Por-HFEF/LCC-4 & 1,158 & 320 & 2,805 & 2,915 & 32 & 24.5 & 0.3710 & 400 & 488 & 1,158 \\
\hline Por-HFEF/LCC-5 & 1,158 & 320 & 2,785 & 2,825 & 45.3 & 24.5 & 0.3710 & 300 & 488 & 1,158 \\
\hline Por-HFEF/LCC-6 & 1,160 & 320 & 2,790 & 2,880 & 37.3 & 24.5 & 0.3700 & 250 & 488 & 1,160 \\
\hline Por-55T-1 & 1,158 & 320 & 2,785 & 2,880 & 41.8 & 24.5 & 0.3700 & 46 & 400 & 488 \\
\hline Por-55T-2 & 1,156 & 320 & 2,810 & 2,745 & 38 & 24.5 & 0.3720 & 44 & 400 & 488 \\
\hline Por-55T-3 & 1,156 & 320 & 2,785 & 2,885 & 40 & 24.3 & 0.3690 & 45 & 400 & 488 \\
\hline Por-55T-4 & 1,156 & 320 & 2,805 & 2,880 & 32 & 24.5 & 0.3700 & 45 & 400 & 488 \\
\hline Por-55T-5 & 1,162 & 320 & 2,790 & 2,866 & 37.8 & 24.5 & 0.3710 & 52 & 300 & 488 \\
\hline Por-55T-6 & 1,158 & 320 & 2,795 & 2,810 & 38.8 & 24.8 & 0.3710 & 47 & 300 & 488 \\
\hline Por-MFTC-1 & 1,160 & 320 & 2,795 & 2,800 & 45 & 24.5 & 0.3700 & 44 & 400 & 488 \\
\hline Por-MFTC-2 & 1,160 & 320 & 2,790 & 2,820 & 45.3 & 24.5 & 0.3700 & 45 & 400 & 488 \\
\hline Por-MFTC-3 & 1,160 & 320 & 2,800 & 2,805 & 43.3 & 24.5 & 0.3700 & 47 & 400 & 488 \\
\hline Por-MFTC-4 & 1,158 & 320 & 2,800 & 2,880 & 33.5 & 24.5 & 0.3720 & 47 & 400 & 488 \\
\hline Por-MFTC-5 & 1,160 & 320 & 2,780 & 2,875 & 37.5 & 24.5 & 0.3700 & 46 & 300 & 488 \\
\hline Por-MFTC-6 & 1,158 & 320 & 2,785 & 2,850 & 40.3 & 24.5 & 0.3690 & 250 & 488 & 1,158 \\
\hline Minimum & 1,156 & 320 & 2,780 & 2,745 & 32 & 24.3 & 0.3690 & 43 & 250 & 488 \\
\hline Maximum & 1,164 & 320 & 2,870 & 2,920 & 46 & 25 & 0.3740 & 52 & 440 & 488 \\
\hline Average & 1,159 & 320 & 2,800 & 2,836 & 39 & 24 & 0.3706 & 46 & 372 & 488 \\
\hline Standard Deviation & 2 & 0 & 24 & 48 & 5 & 0 & 0.0011 & 2 & 52 & 0 \\
\hline Coefficent of Variation $\%$ & 0 & 0 & 1 & 2 & 13 & 1 & 0.2968 & 5 & 14 & 0 \\
\hline
\end{tabular}


Table 14. Correlation data for concrete porosity as a function of concrete mix components.

\begin{tabular}{lr}
\hline \multicolumn{1}{c}{ Regression Statistics } \\
\hline Multiple R & 0.41 \\
R Square & 0.17 \\
Adjusted R Square & 0.04 \\
Standard Error & 1.20 \\
Observations & 24 \\
\hline
\end{tabular}

ANOVA

\begin{tabular}{|c|c|c|c|c|c|}
\hline & df & SS & MS & $\mathbf{F}$ & Significance F \\
\hline Regression & 3 & 5.81 & 1.94 & 1.34 & 0.29 \\
\hline Residual & 20 & 28.91 & 1.45 & & \\
\hline Total & 23 & 34.72 & & & \\
\hline
\end{tabular}

\begin{tabular}{|c|c|c|c|c|c|c|c|c|}
\hline & Coefficients & Standard Error & t Stat & P-value & Lower 95\% & Upper $95 \%$ & Lower $95.0 \%$ & Upper $95.0 \%$ \\
\hline Intercept & $6.34 \mathrm{E}+01$ & $8.66 \mathrm{E}+01$ & 7.33E-01 & 4.72E-01 & $-1.17 \mathrm{E}+02$ & $2.44 \mathrm{E}+02$ & $-1.17 \mathrm{E}+02$ & $2.44 \mathrm{E}+02$ \\
\hline Water/cement ratio $(\mathrm{w} / \mathrm{cm})$ & $-1.32 \mathrm{E}+02$ & $2.37 \mathrm{E}+02$ & $-5.57 \mathrm{E}-01$ & $5.84 \mathrm{E}-01$ & $-6.25 \mathrm{E}+02$ & $3.62 \mathrm{E}+02$ & $-6.25 \mathrm{E}+02$ & $3.62 \mathrm{E}+02$ \\
\hline Glenium superplasticizer & 5.92E-02 & $1.06 \mathrm{E}-01$ & $5.57 \mathrm{E}-01$ & $5.84 \mathrm{E}-01$ & $-1.62 \mathrm{E}-01$ & $2.81 \mathrm{E}-01$ & $-1.62 \mathrm{E}-01$ & $2.81 \mathrm{E}-01$ \\
\hline NC534 accelerator & $-8.16 \mathrm{E}-03$ & $4.43 \mathrm{E}-03$ & $-1.84 \mathrm{E}+00$ & 8.02E-02 & $-1.74 \mathrm{E}-02$ & $1.08 \mathrm{E}-03$ & $-1.74 \mathrm{E}-02$ & $1.08 \mathrm{E}-03$ \\
\hline
\end{tabular}




\subsection{Permeability Test Data}

Air-saturated permeability tests were obtained for six random Mix \#3 hardened concrete samples from each vault array. Tests were performed by TerraTek, a subsidiary of Schlumberger, using methods recommended by API RP-40. The following test methods were applied to samples dried at $104^{\circ} \mathrm{C}$ until the weights were stable:

- Helium Porosimetry. Helium expansion was used to determine grain volume, using the Boyles' Law technique. Gas porosimetry (for grain volume) is based on Boyle's Law, which holds that for an ideal gas, at constant temperature, the volume of the gas will vary inversely with pressure according to: $\frac{P_{1}}{P_{2}}=\frac{V_{2}}{V_{1}}$, where $\mathrm{P}_{1}$ is the initial pressure in the initial volume $\mathrm{V}_{1}$ and $\mathrm{P}_{2}$ is the final pressure at volume $\mathrm{V}_{2}$. The porosimeter consists of a steel vessel connected to a gas reservoir through high-pressure tubing. The porosimeter is calibrated by placing a series of steel billets of known volume into a gas expansion chamber. Calibration consists of sequentially increasing volume $\mathrm{V}_{2}$ by known amounts. As $\mathrm{V}_{2}$ increases, the ratio $\mathrm{P} 1 / \mathrm{P} 2$ also increases. Linear regression is performed to determine the relationship between the measured ratio, $\mathrm{P}_{1} / \mathrm{P}_{2}$, and the sample volume such that: $V_{s}=m \times \frac{P_{1}}{P_{2}}+b$. The experimentally determined slope, $m$, thus gives the proportionality between the sample volume and the pressure ratio; whereas the Vs intercept, $b$, represents the zero offset (i.e., due to the dead volume in the porosimeter). These values of $m$ and $b$ are used in subsequent measurements of grain volume. To determine grain density, the billets are replaced by the sample, and the resultant pressure is measured, allowing calculation of $\mathrm{V}_{\mathrm{g}}$.

- Bulk volume $\mathrm{V}_{\mathrm{b}}$ was determined from the fluid volume displaced by the submerged test sample.

- Sample masses were determined using electronic balances.

- Effective porosity was calculated as: $=1-\frac{\rho_{d}}{\rho_{g}}$, where $\rho_{\mathrm{d}}$ is the dry bulk density and $\rho_{\mathrm{g}}$ is the grain density.

- Grain density was determined as: $\rho_{g}=\frac{m_{d}}{V_{g}}$, where $m d$ is the mass of the dry sample and $\mathrm{V}_{\mathrm{g}}$ is the corresponding grain volume.

- Grain volume, Vg was determined using the Boyle's Law double cell technique. The specimens were not subject to confining stress during the tests.

- Single-Phase Gas Permeability (Nitrogen). Gas-phase permeability was measured at four different hydrostatic-confining pressures using the pressure fall off method (API RP 40 6.4.1.1, PressureFalloff, Axial Gas Flow). During the tests, the pore fluid was nitrogen gas and the samples were jacketed in Viton tubing to prevent fluid bypassing the sample. Gas permeability $\mathrm{k}_{\mathrm{g}}$ was calculated using the Darcy equation modified for a compressible gas:

$$
k_{g}=-\frac{Q_{2}}{A}\left[\frac{2 P_{2} L}{P_{2}^{2}-P_{1}^{2}}\right] \mu=v_{2}\left(\frac{P_{2}}{P_{m}}\right)\left(\frac{L}{\Delta P}\right) \mu
$$

where $\mathrm{v}_{2}=\mathrm{Q}_{2} / \mathrm{A}$ and $\mathrm{Q}_{2}$ is the volumetric flow rate (or "discharge rate") at the downstream end, $\mathrm{A}$ is the cross-sectional area of the sample, $\mathrm{P}_{1}$ and $\mathrm{P}_{2}$ are the gas pressures at the upstream and downstream reservoirs, $\mu$ is the gas viscosity, $\mathrm{L}$ is the length of the sample in the macroscopic flow direction, and $\mathrm{P}_{\mathrm{m}}=1 / 2\left(\mathrm{P}_{1}+\mathrm{P}_{2}\right)$.

Resultant data are given in Table 16 for the 24 hardened concrete samples. Table 16, Column 1 contains the sample designator and Column 2 contains the concrete batch ticket number. Columns 3 through 5 contain the dates the test cylinders were poured, the dates the permeability data were measured, and the hold time between the two dates. Columns 6 through 8 contain the as-received concrete sample density, the dry density after oven drying, and the calculated grain density used to determine effective 
porosity. Column 9 contains effective porosity that can be compared to total porosity given in Table 11 . Gas-phase (nitrogen) permeability is given in milliDarcies in Columns 10 through 13 at increasing confining pressures as indicated in the table header.

Data important to concrete performance include the following:

- Dry Bulk Density. This is important to the shielding function of the upper portion of the vault risers. The data shown in Table 16 were not obtained for the shield plugs. The dry density reported in Table 16 can be compared to the bulk density reported using the methods in ASTM C642 in Table 11. The average value for bulk density using the ASTM C642 method for concrete samples with hold times of 28 to 90 days was determined to be $134 \mathrm{lb} / \mathrm{ft}^{3}$ with a standard deviation of $3 \mathrm{lb} / \mathrm{ft}^{3}$ and a coefficient of variation of $2 \%$. Using the AP RP-40 method, the average dry bulk density for concrete samples ranging in hold times of 15 to 104 days is $135 \mathrm{lb} / \mathrm{ft}^{3}$, with a standard deviation of $3 \mathrm{lb} / \mathrm{ft}^{3}$ and a coefficient of variation of $2.1 \%$. Therefore, the dry bulk density using both methods is equivalent.

- Effective Porosity. Effective porosity is more useful than total porosity provided in Section 5.1 because it gives a measure of the interconnected pore space influencing travel times for chemicals, air, and water. The average effective porosity was determined to be $11.9 \%$ compared to a total porosity of $14.3 \%$, with a standard deviation of $1.2 \%$ (compared to $1.2 \%$ for total porosity) and coefficient of variation of $10.2 \%$. While the average effective porosity is smaller than the average total porosity, the standard deviations and coefficient of variation for effective porosity is equivalent or higher. This is attributable to the wider range in hold times prior to sample testing as explained in Section 5.1. For comparison, Figure 10 provides effective porosity versus total porosity for samples having the same batch ticket number. While this figure is somewhat informative, note that sample hold times where not equivalent for each measured value, making direct use of the data problematic.

During the concrete mix-design selection process, four cured concrete samples were tested using the same procedure by TerraTek. The reported values are shown in Figure 11. The range of effective porosity values was 9.73 to $11.76 \%$, which is lower than the values measured on the cured concrete cylinders tested during production of the prefabricated concrete components.

- Gas-Phase Permeability at Low Confining Pressures. Gas-phase permeability is important to concrete durability because it determines the flow rate of gases through concrete under given pressure gradients and can be scaled to determine the water-phase flow rate through concrete. Gas-phase permeability for all confining pressures is given in Figure 12. As shown in the figure, the gas-phase permeability decreases with increasing confining pressure as the confining pressure exerts a higher stress field on the core sample. Gas-phase permeability under low confining pressures is more appropriate for the vault component than under high confining pressures because of the shallow burial and relatively loose fill around the vaults during operations and after the final engineered cover is emplaced. At 500-psi confining pressure, the average gas-phase permeability was reported to be $0.083 \mathrm{mDarcy}$ with a standard deviation of $0.014 \mathrm{mDarcy}$ and coefficient of variation of $16.76 \%$. The range of gas-phase permeability was 0.045 to $0.1 \mathrm{mDarcy}$, which is quite small.

During the concrete mix-design selection process, four cured concrete samples were tested using the same procedure by TerraTek. The reported values are shown in Figure 11. At a confining pressure of $500 \mathrm{psi}$, the range of values was 0.031 to $0.045 \mathrm{mDarcy}$, which is lower than the values measured on the cured concrete cylinders tested during production of the prefabricated concrete components.

Given that the range in hold times is quite large for these data, the relatively small coefficient of variation for dry bulk density, and effective porosity shows that concrete component properties are uniform with very little overall variability.

Table 17 provides the statistical correlation between the gas-phase permeability at 500-psi confining pressure and other measured parameters obtained using the API RP-40 methods. The P-value less than 0.1 for dry bulk density, grain density, and effective porosity indicates a relatively high degree of correlation 
for these parameters to gas-phase permeability, although a linear relationship between gas-phase permeability and effective porosity is not apparent (see Figure 13).

Table 18 provides the concrete batch ticket (i.e., mix ticket data) for each of the tested samples. This table contains the amount of aggregate (i.e., gravel and sand) added to the cement, the pozzolan (i.e., flyash) amounts, and the water/cement ratio given in Column 8. The amounts of admixtures used in each of the tested concrete batches are provided in Columns 9 through 11. Summary statistics for the concrete components indicate that the water/cement ratio is within specifications and the highest variability in concrete component quantities occurs with the accelerator with a coefficient of variation equal to $15 \%$. Variability in the water added is accounted for in the water/cement ratio, which accounts for the moisture content of the aggregate.

Variation in gas-phase permeability is not attributable to variation in the NC534 accelerator as shown by the low P-value in Table 19. Additionally, there is little correlation between permeability and water/cement ratio or with the Glenium superplasticizer.

\subsection{Chloride Diffusion Coefficient}

The apparent diffusion coefficient for chloride was obtained during the concrete mix design process for Mix \#2 and Mix \#3 using ASTM C1556-11a, "Standard Test Method for Determining the Apparent Chloride Diffusion Coefficient of Cementitious Mixtures by Bulk Diffusion." Results are shown in Figures 14 and 15 and are reproduced from PLN-4952. The diffusion coefficient for Mix \#2 was determined to be $1.6 \mathrm{E}-12 \mathrm{~m}^{2} / \mathrm{sec}$ and $1.7 \mathrm{E}-12 \mathrm{~m} / \mathrm{sec}$ for Mix $\# 3$.

\subsection{Density and Compressive Strength Test Data}

Fresh concrete density and compressive strength were measured for each component fabricated (a total of 448 bases, risers, and plugs; two CVASs, and 247 perimeter blocks). Dry density at 14 and 28-days was also measured for all plugs, perimeter blocks, and CVASs. Individual measurements are recorded on either PLN-5077 or PLN-5460. Completed records are maintained in the INL Vendor Data System under Project 31055. Summary statistical analyses are provided in Table 15.

Design criteria for dry density was determined via calculation for radiation shielding performance (ECAR-2747). It was determined that plugs and CVASs should have a minimum dry density of 134 pounds per cubic foot (pcf); no minimum dry density requirement was established for the vault bases and risers. Design criteria for compressive strength is identified in SPC-1437 as a minimum 28-day compressive strength of 5,000 psi for all concrete components.

As shown in Table 15, the as-fabricated concrete vault components meet or exceed the design criteria. The as-constructed density and compressive strength data have been incorporated into the analyses supporting the updated PA.

\subsection{Alkali-Silica Reaction Test Data}

As determined in the RP-212 report and confirmed in concrete mix design trials for RH-LLW vault components, the aggregate sources used are subject to ASR with concrete. To mitigate the ASR potential, the concrete mix designs for vault components shown in the Vault Concrete Mix Design Report (PLN-4953) (i.e., a low-alkali cement, a pozzolan [fly ash], and a lithium-based chemical admixture) were used as recommended by ACI 318-11. With the specific admixtures identified in PLN-4952, the potential for ASR was reduced to $0.02 \%$ average length change. The admixture dosage specified in PLN-4952 is identified in batch tickets that are included in component fabrication quality control records. Completed quality control records are maintained in the INL Vendor Data System under Project 31055. Review of the batch tickets confirms that the admixture dosage met design specifications. 
Table 15. Concrete density and compressive strength summary statistics by component type.

\begin{tabular}{|c|c|c|c|c|c|}
\hline & Plug & CVAS & Base & Upper & Perimeter \\
\hline \multicolumn{6}{|l|}{ Wet Density } \\
\hline Mean (pcf) & 137.1 & 138.5 & 142.6 & 142.6 & 136.9 \\
\hline Standard Deviation (pcf) & 0.1 & NA & NA & 0.0 & 0.1 \\
\hline Minimum (pcf) & 134.3 & 138.5 & 139.9 & 139.9 & 134.3 \\
\hline Maximum (pcf) & 141.0 & 138.5 & 145.0 & 145.0 & 141.0 \\
\hline Number & 448 & 2 & 448 & 448 & 247 \\
\hline \multicolumn{6}{|l|}{ Dry Density (28-day) } \\
\hline Mean (pcf) & 136.2 & 137.8 & NA & NA & NA \\
\hline Standard Deviation (pcf) & 0.1 & NA & NA & NA & NA \\
\hline Minimum (pcf) & $132.5^{\mathrm{a}}$ & 137.8 & NA & NA & NA \\
\hline Maximum (pcf) & 140.3 & 137.8 & NA & NA & NA \\
\hline Number & 448 & 2 & NA & NA & NA \\
\hline \multicolumn{6}{|c|}{ Compressive Strength (28-day) } \\
\hline Mean (psi) & $6,467.8$ & $7,680.0$ & $7,878.4$ & $7,871.8$ & $6,419.2$ \\
\hline Standard Deviation (psi) & 15.8 & 0.0 & 24.4 & 24.5 & 18.4 \\
\hline Minimum (psi) & $5,700.0$ & $7,680.0$ & $6,450.0$ & $6,450.0$ & $5,700.0$ \\
\hline Maximum (psi) & $7,700.0$ & $7,680.0$ & $10,940.0$ & $10,940.0$ & $7,150.0$ \\
\hline Number & 448 & 2 & 448 & 448 & 247 \\
\hline
\end{tabular}

\section{CONCLUSIONS}

This report summarizes the concrete component testing process, including the quality assurance process imposed during vault fabrication, and data necessary to support quantitative assessment of concrete durability. The vault quality assurance program resulted in components with insignificant defects and damage during the fabrication stage and vault installation stage. The test data summarized in this report are within the expected variation for each concrete parameter, with the exception of gas-phase permeability and effective proposity in the cured concrete, which are slightly higher than data used to select the concrete mix designs. These differences are evaluated in Appendix D of the PA (DOE-ID 2017). The PA demonstrates, based on the combined influence of hydrologic and concrete performance, that the vault system is expected to exceed the 500 year concrete longevity requirement specified in SPC-1437. 
Table 16. Concrete permeability, porosity, and density data using API RP-40 methods.

\begin{tabular}{|c|c|c|c|c|c|c|c|c|c|c|c|c|}
\hline \multirow[b]{2}{*}{ Sample Name } & \multirow[b]{2}{*}{$\begin{array}{c}\text { Batch } \\
\text { ID }\end{array}$} & \multicolumn{3}{|c|}{ Dates (2016) } & \multicolumn{3}{|c|}{ Density $\left(\mathbf{l b} / \mathbf{f t}^{\mathbf{3}}\right)$} & \multirow[b]{2}{*}{$\begin{array}{c}\text { Effective } \\
\text { (Ambient) } \\
\text { Porosity }\left(\phi_{\mathrm{eff}}\right)\end{array}$} & \multicolumn{4}{|c|}{ Gas Permeability (mD) } \\
\hline & & Poured & Tested & $\begin{array}{l}\text { Held } \\
\text { Days } \\
\end{array}$ & $\begin{array}{c}\text { As Received } \\
\left(\rho_{a r}\right)\end{array}$ & $\begin{array}{c}\text { Dry Bulk } \\
\left(\rho_{\text {bulk }}\right)\end{array}$ & $\begin{array}{l}\text { Grain } \\
\left(\rho_{\text {grain }}\right)\end{array}$ & & $\begin{array}{c}\mathbf{5 0 0} \mathbf{p s i} \\
\text { Confining } \\
\text { Stress } \\
\end{array}$ & $\begin{array}{c}750 \text { psi } \\
\text { Confining } \\
\text { Stress } \\
\end{array}$ & $\begin{array}{c}1,000 \text { psi } \\
\text { Confining Stress } \\
\end{array}$ & $\begin{array}{c}1,250 \text { psi } \\
\text { Confining Stress }\end{array}$ \\
\hline PorNuPac1 & 51598 & $2 / 9$ & $6 / 2$ & 114 & 140.0 & 131.9 & 150.3 & 12.3 & 0.111 & 0.103 & 0.095 & 0.089 \\
\hline PorNuPac2 & 52148 & $2 / 19$ & $6 / 2$ & 104 & 145.5 & 138.7 & 153.4 & 9.6 & 0.045 & 0.041 & 0.038 & 0.035 \\
\hline PorNuPac3 & 52948 & $3 / 23$ & $6 / 2$ & 71 & 142.5 & 134.5 & 151.3 & 11.1 & 0.072 & 0.065 & 0.061 & 0.057 \\
\hline PorNuPac4 & 53325 & $4 / 4$ & $6 / 2$ & 59 & 147.0 & 140.7 & 155.3 & 9.4 & 0.08 & 0.074 & 0.069 & 0.064 \\
\hline PorNuPac5 & 53368 & $4 / 5$ & $6 / 2$ & 58 & 139.7 & 130.5 & 149.7 & 12.8 & 0.096 & 0.088 & 0.082 & 0.077 \\
\hline PorNuPac6 & 53405 & $4 / 6$ & $6 / 3$ & 58 & 143.8 & 136.5 & 152.9 & 10.8 & 0.069 & 0.062 & 0.056 & 0.052 \\
\hline Por-HFEF/LCC-1 & 53441 & $4 / 7$ & $6 / 3$ & 57 & 144.0 & 135.8 & 152.4 & 10.9 & 0.08 & 0.073 & 0.068 & 0.064 \\
\hline Por-HFEF/LCC-2 & 53572 & $4 / 12$ & $6 / 3$ & 52 & 140.7 & 132.1 & 151.5 & 12.8 & 0.093 & 0.086 & 0.081 & 0.078 \\
\hline Por-HFEF/LCC-3 & 54498 & $5 / 9$ & $6 / 3$ & 25 & 142.4 & 133.7 & 152.7 & 12.5 & 0.092 & 0.083 & 0.077 & 0.072 \\
\hline Por-HFEF/LCC-4 & 55127 & $5 / 25$ & $6 / 9$ & 15 & 141.0 & 132.3 & 153.3 & 13.7 & 0.088 & 0.079 & 0.072 & 0.067 \\
\hline Por-HFEF/LCC-5 & 56103 & $6 / 22$ & $7 / 29$ & 37 & 143.0 & 135.5 & 153.9 & 12.0 & 0.098 & 0.089 & 0.08 & 0.075 \\
\hline Por-HFEF/LCC-6 & 57100 & $7 / 26$ & $8 / 16$ & 21 & 142.1 & 133.9 & 152.5 & 12.2 & 0.083 & 0.077 & 0.072 & 0.068 \\
\hline Por-55T-1 & 53485 & $4 / 8$ & $6 / 3$ & 56 & 143.3 & 135.1 & 152.8 & 11.6 & 0.084 & 0.077 & 0.071 & 0.066 \\
\hline Por-55T-2 & 53485 & $4 / 18$ & $6 / 3$ & 46 & 144.3 & 136.8 & 154.5 & 11.5 & 0.098 & 0.09 & 0.081 & 0.075 \\
\hline Por-55T-3 & 53770 & $5 / 9$ & $6 / 3$ & 25 & 140.3 & 131.7 & 152.1 & 13.4 & 0.079 & 0.073 & 0.068 & 0.063 \\
\hline Por-55T-4 & 54500 & $5 / 25$ & $6 / 9$ & 15 & 144.8 & 137.5 & 156.1 & 11.9 & 0.084 & 0.075 & 0.07 & 0.066 \\
\hline Por-55T-5 & 55077 & $6 / 3$ & $7 / 15$ & 42 & 147.6 & 141.2 & 157.2 & 10.2 & 0.086 & 0.073 & 0.068 & 0.063 \\
\hline Por-55T-6 & 55446 & $6 / 8$ & $7 / 15$ & 37 & 144.6 & 137.2 & 155.8 & 11.9 & 0.076 & 0.065 & 0.06 & 0.056 \\
\hline Por-MFTC-1 & 55604 & $4 / 11$ & $6 / 3$ & 53 & 142.3 & 134.5 & 152.0 & 11.6 & 0.1 & 0.092 & 0.085 & 0.081 \\
\hline Por-MFTC-2 & 53516 & $4 / 18$ & $6 / 3$ & 46 & 143.1 & 135.2 & 152.7 & 11.5 & 0.065 & 0.059 & 0.054 & 0.05 \\
\hline Por-MFTC-3 & 53762 & $5 / 11$ & $6 / 9$ & 29 & 142.8 & 135.0 & 153.9 & 12.3 & 0.079 & 0.072 & 0.066 & 0.063 \\
\hline Por-MFTC-4 & 54593 & $5 / 20$ & $6 / 9$ & 20 & 143.1 & 135.2 & 154.4 & 12.5 & 0.083 & 0.074 & 0.068 & 0.064 \\
\hline Por-MFTC-5 & 54968 & $6 / 15$ & $7 / 15$ & 30 & 140.4 & 131.2 & 153.4 & 14.5 & 0.077 & 0.07 & 0.066 & 0.063 \\
\hline Por-MFTC-6 & 55840 & $7 / 6$ & $7 / 29$ & 23 & 143.8 & 136.2 & 155.4 & 12.4 & 0.066 & 0.06 & 0.055 & 0.052 \\
\hline Minimum & & & & & 139.7 & 130.5 & 149.7 & 9.4 & 0.05 & 0.04 & 0.04 & 0.04 \\
\hline Maximum & & & & & 147.6 & 141.2 & 157.2 & 14.5 & 0.10 & 0.09 & 0.09 & 0.08 \\
\hline Average & & & & & 143.0 & 135.1 & 153.3 & 11.9 & 0.08 & 0.08 & 0.07 & 0.07 \\
\hline Std. Dev. & & & & & 2.1 & 2.8 & 1.8 & 1.2 & 0.01 & 0.01 & 0.01 & 0.01 \\
\hline $\begin{array}{l}\text { Coefficent of } \\
\text { Variation } \%\end{array}$ & & & & & 1.5 & 2.1 & 1.2 & 10.2 & 16.76 & 17.42 & 17.32 & 17.68 \\
\hline
\end{tabular}




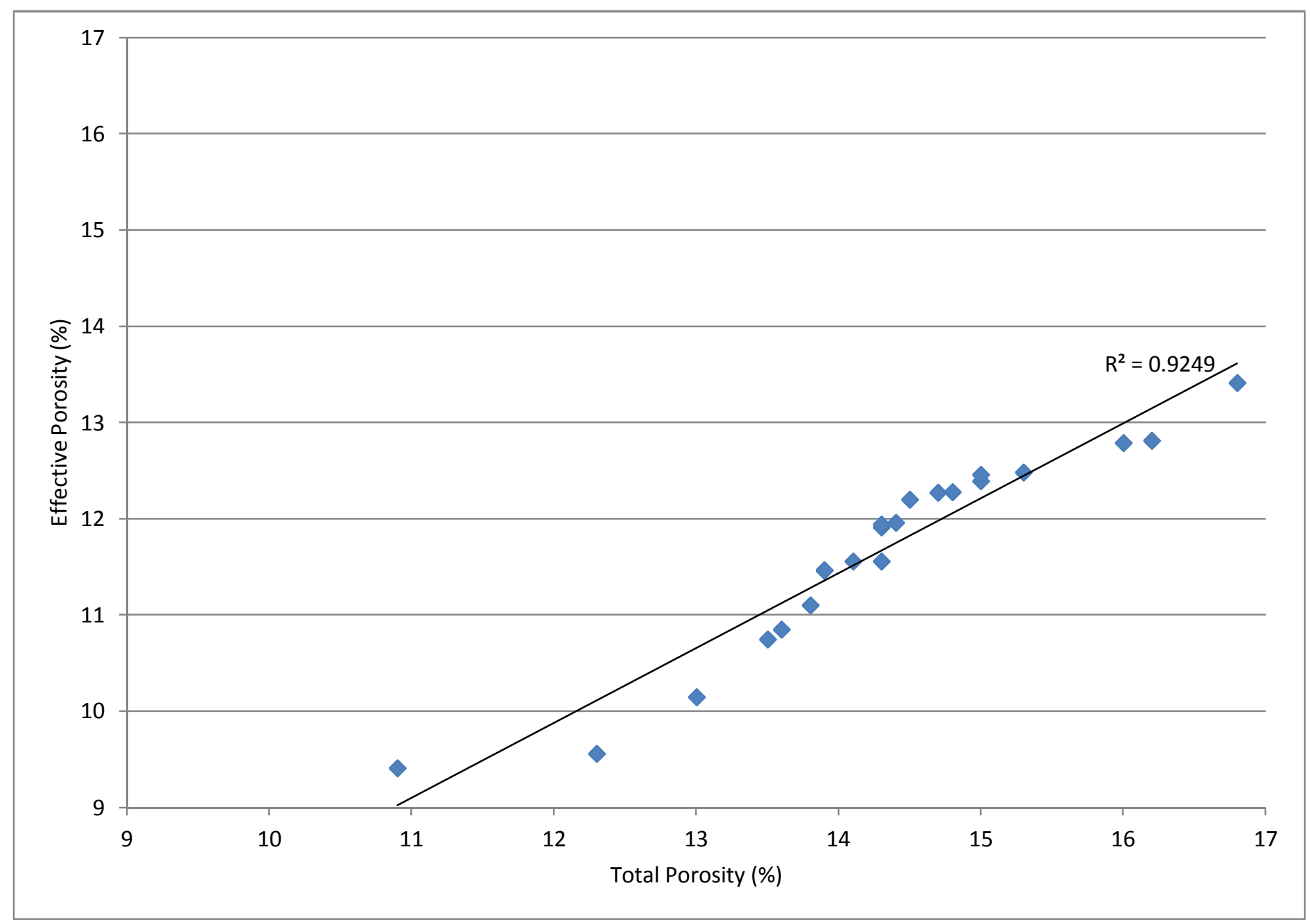

Figure 10. Effective porosity versus total porosity for samples having the same batch ticket number. 


\begin{tabular}{|c|c|c|c|c|c|c|c|}
\hline \multicolumn{6}{|c|}{$\begin{array}{l}\text { AREVA Federal Services LLC } \\
\text { Oldcastle Concrete } \\
\text { Routine Core Analysis Results Summary } \\
504914 \\
\text { February 6, } 2015\end{array}$} & \multicolumn{2}{|c|}{ 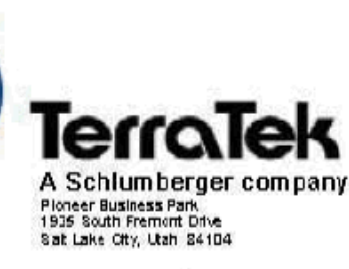 } \\
\hline Sample ID & $\begin{array}{l}\text { Sample } \\
\text { Length } \\
\text { (cm) }\end{array}$ & $\begin{array}{c}\text { Sample } \\
\text { Diameter } \\
\text { (cm) }\end{array}$ & $\begin{array}{c}\text { Dry Bulk } \\
\text { Density } \\
\text { (g/cc) }\end{array}$ & $\begin{array}{c}\text { Grain } \\
\text { Density } \\
\text { (g/cc) }\end{array}$ & $\begin{array}{c}\text { Ambient } \\
\text { Porosity } \\
(\%)\end{array}$ & $\begin{array}{c}\text { SS Gas } \\
\text { Permeability } \\
\text { (mD) }\end{array}$ & \\
\hline $3 A-500 \mathrm{psi}$ & 2.494 & 3.813 & 2.233 & 2.489 & 10.28 & 0.045 & \\
\hline $750 \mathrm{psi}$ & & & & & & 0.041 & \\
\hline $1000 \mathrm{psi}$ & & & & & & 0.038 & \\
\hline $1250 \mathrm{psi}$ & & & & & & 0.036 & \\
\hline $3 \mathrm{~B}-500 \mathrm{psi}$ & 2.477 & 3.811 & 2.183 & 2.474 & 11.76 & 0.034 & \\
\hline $750 \mathrm{psi}$ & & & & & & 0.031 & \\
\hline $1000 \mathrm{psi}$ & & & & & & 0.029 & \\
\hline $1250 \mathrm{psi}$ & & & & & & 0.027 & \\
\hline $4 \mathrm{~A}-500 \mathrm{psi}$ & 2.482 & 3.810 & 2.188 & 2.445 & 10.54 & 0.031 & \\
\hline $750 \mathrm{psi}$ & & & & & & 0.028 & \\
\hline $1000 \mathrm{psi}$ & & & & & & 0.026 & \\
\hline $1250 \mathrm{psi}$ & & & & & & 0.025 & \\
\hline $4 \mathrm{~B}-500 \mathrm{psi}$ & 2.509 & 3.813 & 2.257 & 2501 & 9.73 & 0.043 & \\
\hline $750 \mathrm{psi}$ & & & & & & 0.039 & \\
\hline $1000 \mathrm{psi}$ & & & & & & 0.037 & \\
\hline $1250 \mathrm{psi}$ & & & & & & 0.035 & \\
\hline
\end{tabular}

Figure 11. Effective porosity and gas-phase permeability for test samples used to select the concrete mix designs from PLN-4952. 


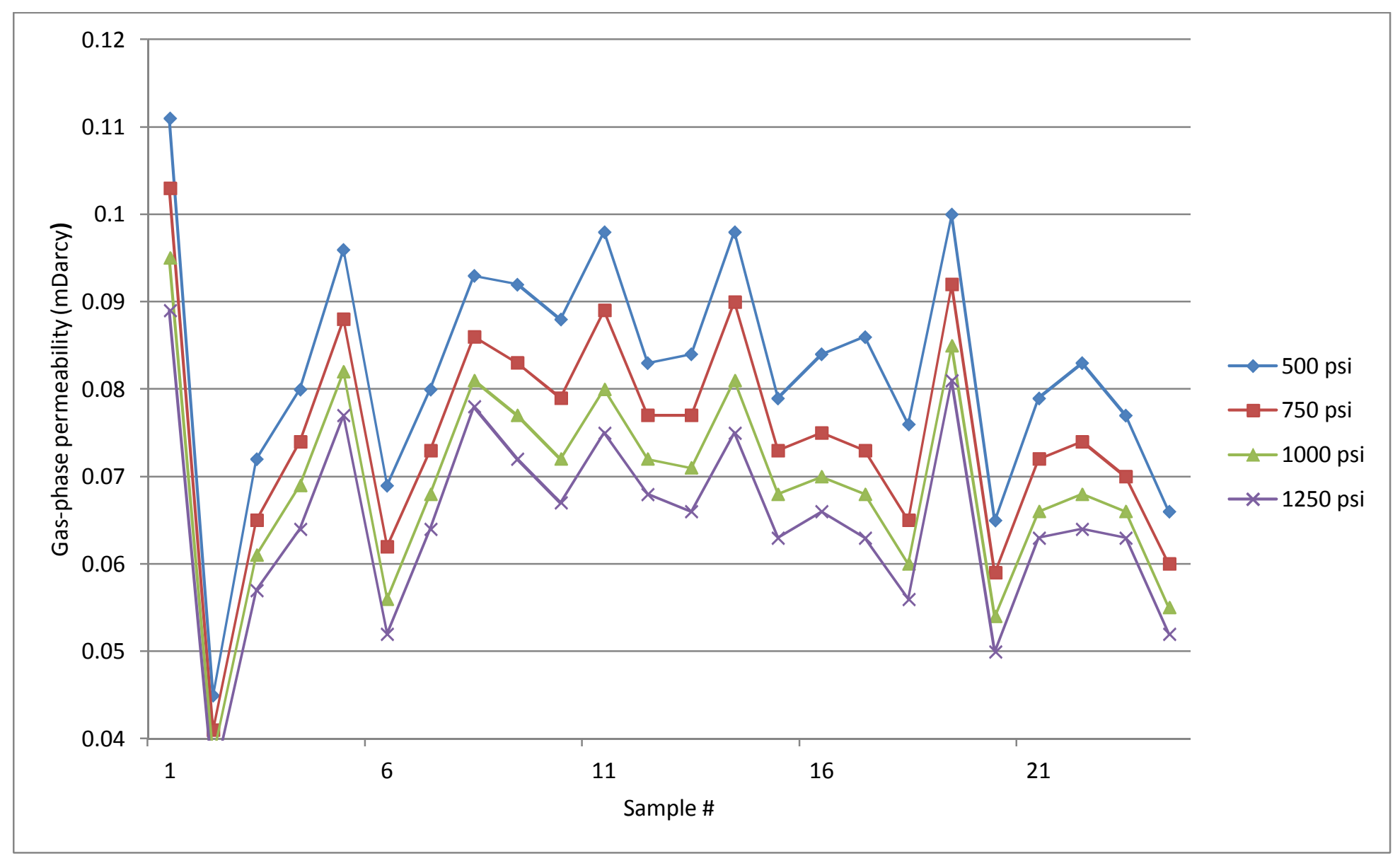

Figure 12. Gas-phase permeability at four different confining pressures. 
Table 17. Correlation between measured values for the gas-phase permeability at 750-psi confining pressure and other API RP-40 data.

\begin{tabular}{lr}
\hline \multicolumn{2}{c}{ Regression Statistics } \\
\hline Multiple R & 0.519 \\
R Square & 0.270 \\
Adjusted R Square & 0.160 \\
Standard Error & 0.013 \\
Observations & 24 \\
\hline
\end{tabular}

\section{ANOVA}

\begin{tabular}{|c|c|c|c|c|c|}
\hline & df & SS & MS & $\mathbf{F}$ & Significance F \\
\hline Regression & 3 & 0.001 & 0.000 & 2.460 & 0.092 \\
\hline Residual & 20 & 0.003 & 0.000 & & \\
\hline Total & 23 & 0.004 & & & \\
\hline
\end{tabular}

\begin{tabular}{|c|c|c|c|c|c|c|c|c|}
\hline & Coefficients & Standard Error & t Stat & P-value & Lower 95\% & Upper 95\% & Lower $95.0 \%$ & Upper $95.0 \%$ \\
\hline Intercept & -3.77 & 2.17 & -1.73 & 0.10 & -8.30 & 0.77 & -8.30 & 0.77 \\
\hline Dry bulk density & 0.21 & 0.11 & 1.87 & 0.08 & -0.02 & 0.45 & -0.02 & 0.45 \\
\hline Grain density & -0.19 & 0.10 & -1.88 & 0.07 & -0.39 & 0.02 & -0.39 & 0.02 \\
\hline Effective porosity & 0.33 & 0.17 & 1.88 & 0.07 & -0.04 & 0.69 & -0.04 & 0.69 \\
\hline
\end{tabular}




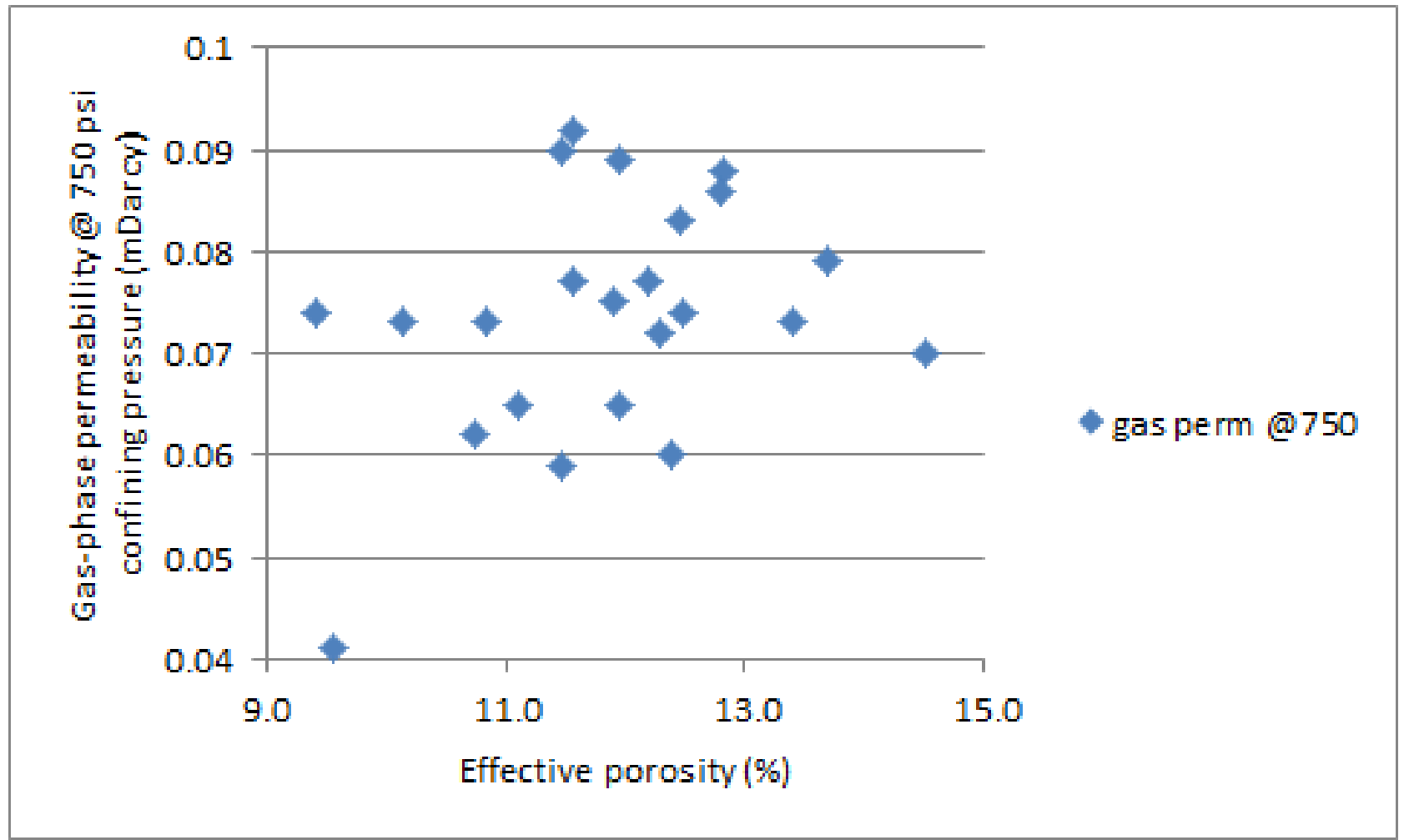

Figure 13. Gas-phase permeability versus effective porosity. 
Table 18. Concrete permeability, porosity, and density sample batch ticket data.

\begin{tabular}{|c|c|c|c|c|c|c|c|c|c|c|c|}
\hline Sample Name & $\begin{array}{c}\text { Batch } \\
\text { ID }\end{array}$ & $\begin{array}{c}\text { Cement } \\
\text { (lb) }\end{array}$ & $\begin{array}{c}\text { Flyash } \\
\text { (lb) }\end{array}$ & $\begin{array}{c}\text { Gravel } \\
\text { (lb) }\end{array}$ & $\begin{array}{c}\text { Sand } \\
\text { (lb) }\end{array}$ & $\begin{array}{l}\text { Water } \\
\text { (gal) }\end{array}$ & $\begin{array}{c}\text { Prewater } \\
\text { (gal) }\end{array}$ & $\begin{array}{c}\text { Water/Cement } \\
\text { Ratio (w/cm) }\end{array}$ & $\begin{array}{c}\text { Glenium (oz) } \\
\text { Superplasticizer } \\
\end{array}$ & $\begin{array}{l}\text { NC534 (oz) } \\
\text { Accelerator } \\
\end{array}$ & $\begin{array}{l}\text { ASR } 30(0 z) \\
\text { Lithium }\end{array}$ \\
\hline PorNuPac1 & 51598 & 1,162 & 320 & 2,870 & 2,770 & 32.8 & 24.8 & 0.3700 & 45 & 440 & 488 \\
\hline PorNuPac2 & 52148 & 1,158 & 320 & 2,780 & 2,830 & 45.8 & 24.3 & 0.3700 & 50 & 360 & 488 \\
\hline PorNuPac3 & 52948 & 1,160 & 320 & 2,810 & 2,785 & 37 & 24.3 & 0.3720 & 45 & 398 & 488 \\
\hline PorNuPac4 & 53325 & 1,158 & 320 & 2,790 & 2,850 & 39.5 & 24.5 & 0.3710 & 45 & 400 & 488 \\
\hline PorNuPac5 & 53368 & 1,160 & 320 & 2,805 & 2,790 & 41 & 24.3 & 0.3700 & 47 & 400 & 488 \\
\hline PorNuPac6 & 53405 & 1,158 & 320 & 2,805 & 2,785 & 42.5 & 24.5 & 0.3700 & 45 & 400 & 488 \\
\hline Por-HFEF/LCC-1 & 53441 & 1,158 & 320 & 2,780 & 2,830 & 44.3 & 24.3 & 0.3740 & 46 & 400 & 488 \\
\hline Por -HFEF/LCC-2 & 53572 & 1,160 & 320 & 2,790 & 2,790 & 43.8 & 24.3 & 0.3710 & 43 & 400 & 488 \\
\hline Por -HFEF/LCC-3 & 54498 & 1,158 & 320 & 2,790 & 2,840 & 39.5 & 24.3 & 0.3710 & 46 & 400 & 488 \\
\hline Por-HFEF/LCC-4 & 55127 & 1,158 & 320 & 2,780 & 2,860 & 35.5 & 24.5 & 0.3700 & 45 & 400 & 488 \\
\hline Por-HFEF/LCC-5 & 56103 & 1,158 & 320 & 2,785 & 2,825 & 45.3 & 24.5 & 0.3710 & 48 & 300 & 488 \\
\hline Por-HFEF/LCC-6 & 57100 & 1,158 & 320 & 2,785 & 2,825 & 44.3 & 24.5 & 0.3700 & 51 & 250 & 488 \\
\hline Por-55T-1 & 53485 & 1,156 & 320 & 2,810 & 2,745 & 38 & 24.5 & 0.3720 & 44 & 400 & 488 \\
\hline Por-55T-2 & 53485 & 1,160 & 320 & 2,785 & 2,840 & 41.8 & 24.3 & 0.3720 & 45 & 400 & 488 \\
\hline Por-55T-3 & 53770 & 1,158 & 320 & 2,800 & 2,820 & 39.5 & 24.8 & 0.3710 & 45 & 400 & 488 \\
\hline Por-55T-4 & 54500 & 1,156 & 320 & 2,805 & 2,880 & 32 & 24.5 & 0.3710 & 45 & 400 & 488 \\
\hline Por-55T-5 & 55077 & 1,162 & 320 & 2,790 & 2,865 & 37.8 & 24.5 & 0.3700 & 52 & 300 & 488 \\
\hline Por-55T-6 & 55446 & 1,158 & 320 & 2,795 & 2,810 & 38.8 & 24.8 & 0.3710 & 47 & 300 & 488 \\
\hline Por-MFTC-1 & 55604 & 1,160 & 320 & 2,795 & 2,800 & 45 & 24.5 & 0.3710 & 44 & 400 & 488 \\
\hline Por-MFTC-2 & 53516 & 1,160 & 320 & 2,790 & 2,820 & 45.3 & 24.5 & 0.3700 & 45 & 400 & 488 \\
\hline Por-MFTC-3 & 53762 & 1,160 & 320 & 2,800 & 2,805 & 43.3 & 24.5 & 0.3700 & 47 & 400 & 488 \\
\hline Por-MFTC-4 & 54593 & 1,158 & 320 & 2,805 & 2,880 & 33.5 & 24.5 & 0.3700 & 47 & 400 & 488 \\
\hline Por-MFTC-5 & 54968 & 1,160 & 320 & 2,780 & 2,875 & 37.5 & 24.5 & 0.3720 & 46 & 300 & 488 \\
\hline Por-MFTC-6 & 55840 & 1,158 & 320 & 2,780 & 2,815 & 45 & 24.5 & 0.3700 & 42 & 250 & 488 \\
\hline Minimum & & 1,156 & 320 & 2,780 & 2,745 & 32 & 24 & 0.370 & 42 & 250 & 488 \\
\hline Maximum & & 1,162 & 320 & 2,810 & 2,880 & 46 & 25 & 0.374 & 52 & 400 & 488 \\
\hline Average & & 1,159 & 320 & 2,796 & 2,822 & 40 & 24 & 0.371 & 46 & 371 & 488 \\
\hline Standard Deviation & & 2 & 0 & 19 & 35 & 4 & 0 & 0.001 & 2 & 54 & 0 \\
\hline Coefficent of Variation $\%$ & & 0 & 0 & 1 & 1 & 11 & 1 & 0.272 & 5 & 15 & 0 \\
\hline
\end{tabular}


Table 19. Correlation data for concrete gas-phase permeability at 500-psi confining pressure as a function of concrete mix components.

\begin{tabular}{lr}
\hline \multicolumn{2}{c}{ Regression Statistics } \\
\hline Multiple R & 0.266 \\
R Square & 0.071 \\
Adjusted R Square & -0.069 \\
Standard Error & 0.014 \\
Observations & 24 \\
\hline
\end{tabular}

\begin{tabular}{|c|c|c|c|c|c|}
\hline & df & SS & MS & $\mathbf{F}$ & Significance F \\
\hline Regression & 3 & 0.0003 & 0.0001 & 0.5078 & 0.6814 \\
\hline Residual & 20 & 0.0041 & 0.0002 & & \\
\hline Total & 23 & 0.0044 & & & \\
\hline
\end{tabular}

\begin{tabular}{|c|c|c|c|c|c|c|c|c|}
\hline & Coefficients & Standard Error & t Stat & P-value & Lower 95\% & Upper $95 \%$ & Lower $95.0 \%$ & Upper $95.0 \%$ \\
\hline Intercept & -0.2234 & 1.1538 & -0.1936 & 0.8484 & -2.6301 & 2.1833 & -2.6301 & 2.1833 \\
\hline Glenium superplasticizer & -0.0001 & 0.0014 & -0.0654 & 0.9485 & -0.0031 & 0.0029 & -0.0031 & 0.0029 \\
\hline NC534 accelerator & 0.0001 & 0.0001 & 1.0300 & 0.3153 & -0.0001 & 0.0002 & -0.0001 & 0.0002 \\
\hline Water/cement ratio $(\mathrm{w} / \mathrm{cm})$ & 0.7746 & 3.0687 & 0.2524 & 0.8033 & -5.6265 & 7.1758 & -5.6265 & 7.1758 \\
\hline
\end{tabular}




\begin{tabular}{llll} 
& & \\
\hline Client: & Applus RTD & CTLGroup Project No: & 391202 \\
Project: & AREVA RH LLW Project & CTLGroup Project Mgr.: & Joni Jones \\
& & Analyst: & MS \\
Contact: & Jerry Harper & Approved: & Cyler Hayes \\
Submitter: & Jerry Harper & Date Analyzed: & December 30, 2014 \\
Date Received: & November 5. 2014 & Date Reported: & December 30, 2014 \\
\hline
\end{tabular}

\begin{tabular}{|c|c|c|}
\hline \multicolumn{3}{|c|}{ ASTM C1556 - 11a } \\
\hline \multicolumn{3}{|c|}{$\begin{array}{l}\text { Standard Test Method for Determining the Apparent Chloride Diffusion Coefficient } \\
\text { of Cementitious Mixtures by Bulk Diffusion }\end{array}$} \\
\hline \multicolumn{3}{|c|}{ Mix 2A, Cylinder 1 - CTLGroup Work Request 38558} \\
\hline Mid-Layer Depth & Measured Chloride & Calculated Chloride \\
\hline $\mathrm{mm}$ & $\mathrm{Cm}, \%$ & Cc, \% \\
\hline 0.5 & 1.086 & 1.072 \\
\hline 1.5 & 0.760 & 0.772 \\
\hline 2.5 & 0.496 & 0.516 \\
\hline 4 & 0.267 & 0.244 \\
\hline 6 & 0.079 & 0.070 \\
\hline 8 & 0.015 & 0.019 \\
\hline 10.5 & 0.008 & 0.009 \\
\hline 14 & 0.007 & 0.008 \\
\hline 55.0 & 0.008 & 0.008 \\
\hline Exposure time, $t$, days & \multicolumn{2}{|c|}{35} \\
\hline Initial Chloride Content, Ci, \% & \multicolumn{2}{|c|}{0.008} \\
\hline Surface Chloride Content, $C_{s,} \%$ & \multicolumn{2}{|c|}{1.23} \\
\hline Calculated Diffusion Coefficient, & \multicolumn{2}{|c|}{1.6} \\
\hline
\end{tabular}

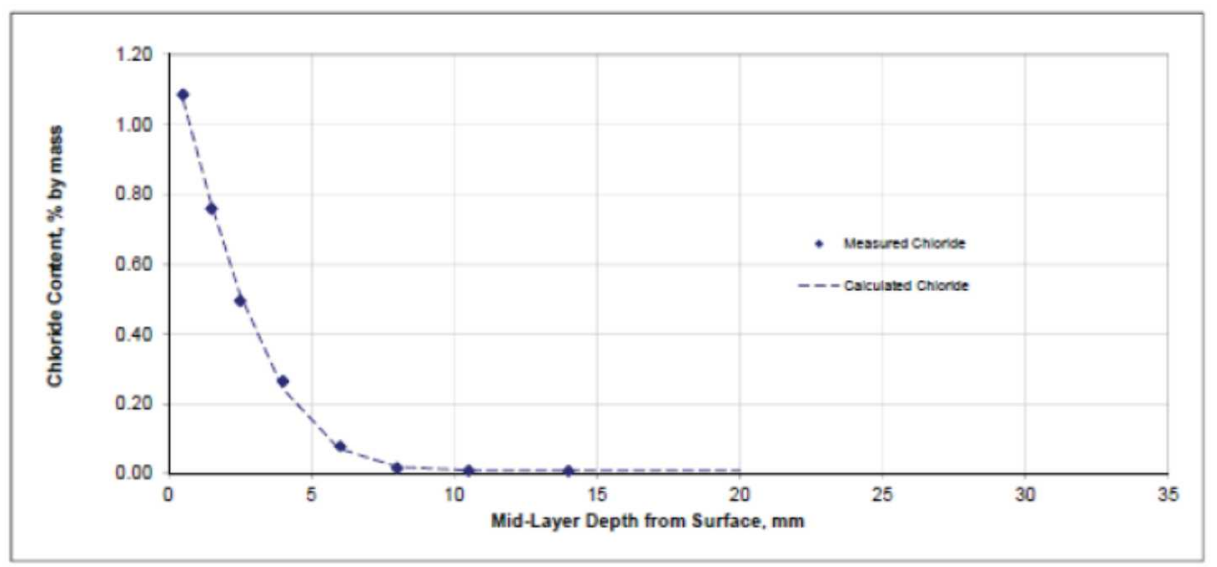

Notes:

1. This report represents specifically the sample provided.

2. The sample was obtained, treated, prepared and calculations conducted following ASTM C1556 - 11a.

3. The chloride content was determined by ASTM C1152-04(2012)

4. This report may not be reproduced except in its entirety.

Figure 14. Apparent chloride diffusion test data for Mix \#2A. 


\section{CTL)GROUP}

\begin{tabular}{|c|c|c|c|c|}
\hline Client: & Applus RTD & & CTLGroup Project No: & 391202 \\
\hline \multirow[t]{2}{*}{ Project: } & \multirow{2}{*}{\multicolumn{2}{|c|}{ AREVA RH LLW Project }} & CTLGroup Project Mgr:: & Joni Jones \\
\hline & & & Analyst: & MS \\
\hline Contact: & Jerry Harper & & Approved: & Cyler Hayes \\
\hline Submitter: & Jerry Harper & & Date Analyzed: & December 30,20 \\
\hline \multirow[t]{20}{*}{ Date Received: } & November 5,2014 & & Date Reported: & December 30,20 \\
\hline & \multicolumn{4}{|c|}{ ASTM C1556-11a } \\
\hline & \multirow{2}{*}{\multicolumn{4}{|c|}{$\begin{array}{l}\text { Standard Test Method for Determining the Apparent Chloride Diffusion Coefficient } \\
\text { of Cementitious Mixtures by Bulk Diffusion }\end{array}$}} \\
\hline & & & & \\
\hline & \multicolumn{4}{|c|}{ Mix 2B, Cylinder 2-CTLGroup Work Request 38558} \\
\hline & Mid-Layer Depth & Measured Chloride & \multicolumn{2}{|c|}{ Calculated Chloride } \\
\hline & $\mathrm{mm}$ & $\mathrm{Cm}, \%$ & \multicolumn{2}{|c|}{$\mathrm{Co}, \%$} \\
\hline & 0.5 & 1.234 & \multicolumn{2}{|c|}{1.210} \\
\hline & 1.5 & 0.857 & \multicolumn{2}{|c|}{0.885} \\
\hline & 2.5 & 0.583 & \multicolumn{2}{|c|}{0.804} \\
\hline & 4 & 0.316 & \multicolumn{2}{|c|}{0.297} \\
\hline & 6 & 0.118 & \multicolumn{2}{|c|}{0.091} \\
\hline & 8 & 0.025 & \multicolumn{2}{|c|}{0.025} \\
\hline & 10.5 & 0.016 & \multicolumn{2}{|c|}{0.009} \\
\hline & 14 & 0.009 & \multicolumn{2}{|c|}{0.008} \\
\hline & 55.0 & 0.008 & \multicolumn{2}{|c|}{0.008} \\
\hline & \multicolumn{2}{|l|}{ Exposure time, $t$, days } & 35 & \\
\hline & Initial Chloride Content, $\mathrm{Ci}, \%$ & \multicolumn{2}{|r|}{0.008} & \\
\hline & Surface Chloride Content, $C_{n}, 96$ & \multicolumn{2}{|r|}{1.38} & \\
\hline & Calculated Diffusion Coefficient, D, $\left(\times 10^{-12}\right)$ & & 1.7 & \\
\hline
\end{tabular}

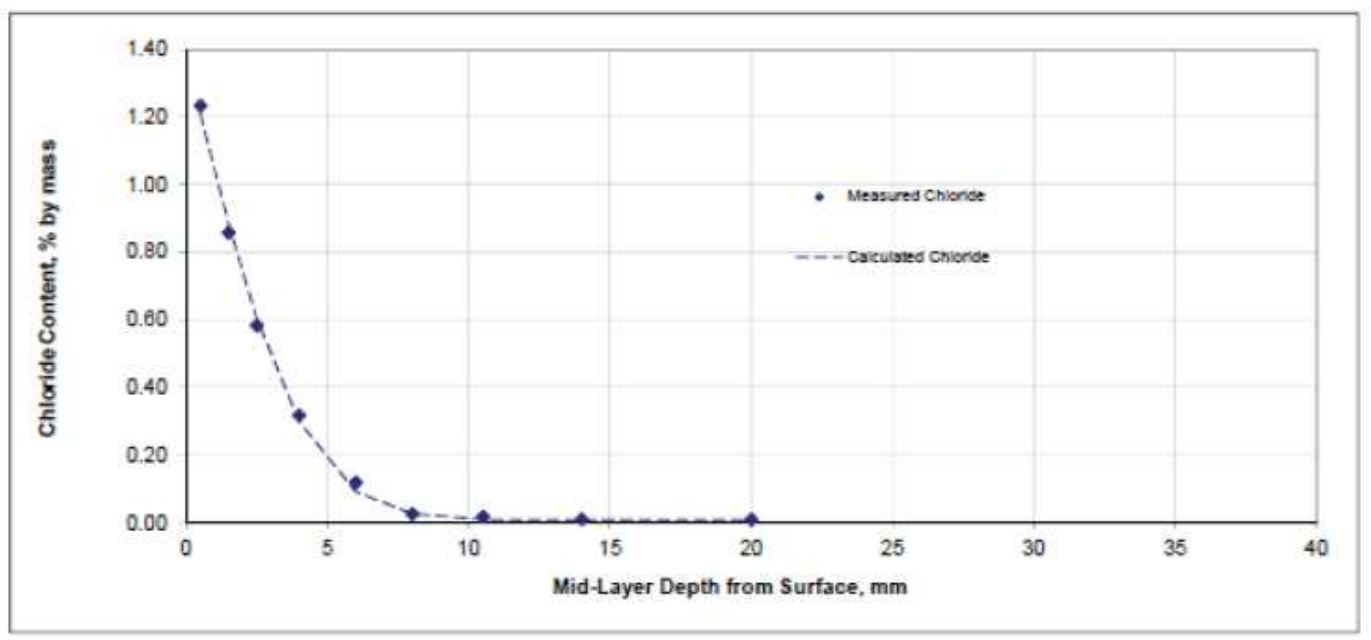

Notes:

1. This report represents specifically the sample provided.

2. The sample was obtained, treated, prepared and calculations conducted following ASTM C1558 - 11 a,

3. The chloride content was determined by ASTM C1152-04(2012) $\boldsymbol{c t}^{\text {t }}$

4. This report may not be reproduced except in its entirety

Figure 15. Apparent chloride diffusion test data for Mix \#3. 


\section{REFERENCES}

ACI 201.2R, “Guide to Durable Concrete,” 2008 Edition, American Concrete Institute.

ACI 224R-01, "Control of Cracking in Concrete Structures," American Concrete Institute, 2001.

ACI 301, "Specifications for Structural Concrete,” American Concrete Institute, 2010.

ACI 318-11, "Building Code Requirements for Structural Concrete and Commentary," American Concrete Institute, 2011.

ACI 349-06, "Code Requirements for Nuclear Safety-Related Concrete Structures and Commentary," American Concrete Institute, 2006 Edition.

ACI 446.1R-91, "Fracture Mechanics of Concrete,” American Concrete Institute, 1991.

American Geotechnics, 2011, Geotechnical Investigation of the Proposed RH-LLW Facility, Butte County, Idaho, American Geotechnics, File No. 10B-G2163, Revision 1.

AWWA C301-99, 1999, "Prestressed Concrete Pressure Pipe, Steel-Cylinder Type," American Water Works Association.

API RP-40, “Recommended Practice for Core Analysis,” American Petroleum Institute.

ASTM C31-17, "Standard Practice for Making and Curing Concrete Test Specimens in the Field," American Society for Testing and Materials, 2017.

ASTM C33, "Standard Specification for Concrete Aggregates," American Society for Testing and Materials.

ASTM C39-14, "Standard Test Method for Compressive Strength of Cylindrical Concrete Specimens," American Society of Testing and Materials, 2014.

ASTM C109-16, "Standard Test Method for Compressive Strength of Hydraulic Cement Mortars (Using 2-in. or [50-mm] Cube Specimens)," American Society of Testing and Materials, 2016.

ASTM C138-17, "Standard Test Method for Density (Unit Weight), Yield, and Air Content (Gravimetric) of Concrete," American Society of Testing and Materials, 2017.

ASTM C150-12, "Standard Specification for Portland Cement," American Society of Testing and Materials, 2012.

ASTM C190-85, "Method of Test for Tensile Strength of Hydraulic Cement Mortars," American Society of Testing and Materials, 1985, withdrawn in 1990.

ASTM C191-13, "Standard Test Methods for Time Setting of Hydraulic Cement by Vicat Needle," American Society of Testing and Materials, 2013.

ASTM C231-14, "Standard Test Method for Air Content of Freshly Mixed Concrete by the Pressure Method," American Society of Testing and Materials, 2014. 
ASTM C260-16, “Standard Specification for Air-Entraining Admixtures for Concrete," American Society of Testing and Materials, 2016.

ASTM C348-14, "Standard Test Method for Flexural Strength of Hydraulic-Cement Mortars," American Society of Testing and Materials, 2014.

ASTM C494-17, "Standard Specification for Chemical Admixtures for Concrete," American Society of Testing and Materials, 2017.

ASTM C596-09, "Standard Test Method for Drying Shrinkage of Mortar Containing Hydraulic Cement," American Society of Testing and Materials, 2009.

ASTM C618-12, "Standard Specification for Coal Fly Ash and Raw or Calcined Natural Pozzolan for Use in Concrete," American Society of Testing and Materials, 2012.

ASTM C642-13, "Standard Test Method for Density, Absorption, and Voids in Hardened Concrete," American Society of Testing and Materials, 2013.

ASTM C1042-99, "Standard Test Method for Bond Strength of Latex Systems Used with Concrete by Slant Shear," American Society of Testing and Materials, 1999, withdrawn in 2008.

ASTM C1064-17, "Standard Test Method for Temperature of Freshly Mixed Hydraulic-Cement Concrete, 2017.

ASTM C1218-99(2008), "Standard Test for Water-Soluble Chloride in Mortar and Concrete," American Society of Testing and Materials, 2008.

ASTM C1556-11, "Standard Test Method for Determining the Apparent Chloride Diffusion Coefficient of Cementitious Mixtures by Bulk Diffusion," American Society of Testing and Materials, 2011.

ASTM C1562-10, "Standard Guide for Evaluation of Materials Used in Extended Service of Interim Spent Nuclear Fuel Dry Storage,” American Society of Testing and Materials, 2010.

DOE-ID, 2012, "Performance Assessment (PA) for the Idaho National Laboratory (INL) Remote-Handled Low-Level Waste (RH-LLW) Disposal Facility," DOE/ID-11466, Revision 1, U.S. Department of Energy Idaho Operations Office, May 2012.

DOE-ID, 2017, "Performance Assessment (PA) for the Idaho National Laboratory (INL) Remote-Handled Low-Level Waste (RH-LLW) Disposal Facility,” DOE/ID-11466, Revision 2, U.S. Department of Energy Idaho Operations Office, January 2017.

DOE Order 435.1, "Radioactive Waste Management," U.S. Department of Energy.

Drawing 788644, Site Layout Plan, Revision 1

Drawing 788645, “55-Ton Cask Vault Array,” Revision 1, Idaho National Laboratory.

Drawing 788648, “NUPAC 14 210L Cask Vault Array,” Revision 1, Idaho National Laboratory.

Drawing 788651, "HFEF-5 Cask and Large Concept Cask Vault Arrays,” Revision 1, Idaho National Laboratory. 
Drawing 788652, "HFEF-5 Cask and Large Concept Cask Vaults," Revision 2, Idaho National Laboratory.

Drawing 788654, “Modified FTC Cask Vault Array,” Revision 1, Idaho National Laboratory.

Drawing 788655, "Modified FTC Cask Vaults,” Revision 2, Idaho National Laboratory.

Drawing 788657, “Performance Assessment Vault Array,” Revision 1, Idaho National Laboratory.

Drawing 788658, “Installation Section and Detail,” Revision 2, Idaho National Laboratory.

Drawing 788766, “Excavation Plan,” Revision 1, Idaho National Laboratory.

Drawing 788767, “Excavation Sections,” Revision 1, Idaho National Laboratory.

Drawing 788768, “Grading Plan - Vault Yard,” Revision 1, Idaho National Laboratory.

Drawing 788769, "Vault Yard Sections,” Revision 0, Idaho National Laboratory.

Drawing 788770, “Vault Yard Section,” Revision 1, Idaho National Laboratory.

ECAR-2747, "Radiation Shielding for the RH—LLW Facility," Revision 4, AREVA Federal Services LLC.

ECAR-2810, "Vault System Structural Design,” Revision 2, AREVA Federal Services LLC.

Edvardson, C., 1999, "Water Permeability and Autogenous Healing of Cracks in Concrete," ACI Materials Journal Technical Paper Title No. 96-M56, ACI Materials Journal, July and August 1999.

INL, 2017, Assessment of the Idaho National Laboratory Remote Handled Low Level Waste Disposal Facility Hydraulic Performance, INL/EXT-17-41649, Idaho National Laboratory, March 2017.

Klinkenberg L. J., 1941, "The Permeability of Porous Media to Liquids and Gases," in Drilling and Productions Practices: American Petroleum Institute, 200-213.

Neville, 2002, “Autogenous Healing - a concrete miracle?” Concrete International, November 2002.

VDR-536953, 2017, QA-RHLLW.07, Revision 3, "Vault Array Field Inspection, Sampling, and Testing Procedure," DelHur Industries .

Report RP-212, 2014, "Lithologic Characterization of Active ITD Aggregate Sources and Implications for Aggregate Quality," March 2014, prepared for the Idaho Transportation Department by the Idaho Geological Survey.

PLN-4952, "Vault Concrete Selection Report,” Revision 1, AREVA Federal Services LLC.

PLN-4953, "Vault Concrete Mix Design Report,” Revision 3, AREVA Federal Services LLC.

PLN-4954, "Vault Concrete Safety-Related Design Parameters," Revision 2, AREVA Federal Services LLC. 
PLN-4956, "Vault Concrete Compliance Test Plan,” Revision 6, AREVA Federal Services LLC.

PLN-4989, Vault Concrete Durability Test Plan,” Revision 0, AREVA Federal Services LLC.

PLN-5077, "Vault Component and Cask-To-Vault Adapting Structures (CVAS) Fabrication Quality Inspection Plan,” Revision 6, AREVA Federal Services LLC.

PLN-5460, "Vault Component and Cask-To-Vault Adapting Structures (CVAS) Fabrication Quality Inspection Plan," Revision 6, AREVA Federal Services LLC.

SDD-410, 2015, "System Design Description for the Remote-Handled Low-Level Waste Disposal Vault System" Revision 2, Idaho National Laboratory, September 2015.

SPC-1437, 2012, "Design-Build-Operate Performance Specification for the Remote-Handled Low-Level Waste Disposal Project," Revision 0, Idaho National Laboratory.

SPC-1857, "Construction Specification - Vault Fabrication for the RH LLW Disposal Project," Revision 6, AREVA Federal Services LLC.

STD-139, 2015, “INL Engineering Standards,” Revision 5, Idaho National Laboratory.

TFR-483, 2015, "Technical and Functional Requirements for Remote-Handled Low-Level Waste Disposal Project," Revision 5, Idaho National Laboratory, May 2015.

Thouvenot, P., Bildstein, O., Munier, I., Cochepin, B., Poyet, S., Bourbon, X., and Treille, E., 2013, "Modeling concrete carbonation in deep geological disposal of intermediate level waste," EPJ Web of Conferences 56, 05004, 2013, article available at http://www.epj-conferences.org or http://dx.doi.org/10.1051/epjconf/20135605004. 


\section{Appendix A, Evaluation of Crack Depth and Explanation of Shrinkage Crack Causes}

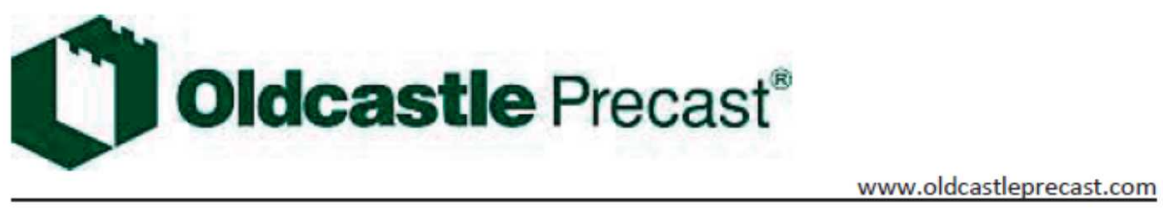

To: Bob Ballard

From: Mike Blackham

\section{Cause}

The plugs are a large mass of concrete with reinforcing throughout to help prevent shrinkage/temperature type cracking. When pouring large mass concrete (minimum dimension in any direction is 5' thick) you always have the possibility and the reality that there will be cracking. As the concrete cures and hydrates there is an enourmous amount of heat that is generated and the product itself expands and contracts during the curing process. This expansion and contraction causes the product to crack. The reinforcing is spaced throughout the product per specification, but is held approximately $1.5^{\prime \prime}$ away from any surface. So the surface of the concrete is the area that is at risk of cracking and is usually the spot that the product does crack. These cracks are typically shallow cracks and do not extend beyond the reinforcing that is placed. In addition to the heat generated during the curing process with mass concrete, you also have the potential for temperature changes during the curing process. Any major change in the concrete temperature adds to the potential of the product expanding and contracting even more, and causes surface cracking. A perfect example of this is any slab on grade concrete. The requirements are to go in and put expansion joints/lines in the concrete at consistent intervals. This gives a relief point for the concrete to release built up stresses from the curing process and the possible temperature changes. It allows for a place for the concrete to crack so that you have a controlled cracking point. The following are descriptions of this process taken from the PCA (Portland Cement Association) Design and Control of Concrete Mixtures:

"Mass concrete is defined by $\mathrm{ACl}$ as any volume of concrete in which a combination of dimensions of the member being cast, the boundary conditions, the characterstics of the conrete mixture, and the ambient conditions can lead to undesirable thermal stresses, cracking, deleterious chemical reactions, or reduction in long term strength as a result of elevated concrete temperature due to heat from hydration. Mass concrete includes not only low-cementitous-content concrete in dams and other massive structures, but also moderate to high-cementitous-content concrete in structural members of bridges and buildings."

\footnotetext{
"As the interior concrete increases in temperature and expands, the surface concrete may be cooling and contracting. This causes tensile stresses that may result in thermal cracks at the surface if the temperature differential between the surface and center is too great. The width and depth of cracks depends upon the temperature differential, physical properties of the concrete, and the reinforcing steel."

"Temperature changes that result in shortening can crack concrete members that are highly restrained by another part of the structure or by ground friction. Consider a long restrained concrete member cast without joints that, after moist curing, is allowed to drop in temperature. As the temperature drops, the
} 
www.oldcastleprecast.com

concrete wants to shorten, but can not because it is restrained longitudinally. The resulting tensile stresses cause the conrete to crack."

"Drying shrinkage is an inherent, unavoidable property of concrete, However, properly positioned reinforcing steel is used to reduce crack widths, or joints are used to predetermine and control the location of cracks. Thermal stress due to fluctuations in ambient temperature also can cause cracking, particularly at an early age."

\section{Verification}

Evaluation on the crack depth was conducted by MTI and Oldcastle. The cracks on component NP-P7 were ground down and the bottom of the cracks exposed. This piece was chosen because it appeared to have the worst cracks. The locations that were chosen were two CAR condition cracks and two others that represent over $90 \%$ of the cracks found on all the plugs. See attached pictures and report completed by Craig Reese. The results show that the cracks ranged from 3/8" deep to 5/8" deep. These were cracks that were measured to be up to 0.019 " in width, which is worst case.

\section{Solution}

After evaluating the cracks and showing that they appear to be shallow type cracks as thought, it confirms that the cracks are more than likely an outcome of pouring mass concrete and temperature fluctuations within the concrete, curing, and yarding. As mentioned in PCA Design and Control of Concrete Mixtures these cracks typically form early in the curing/hydration process of concrete and are near the surface of the product.

The cracks are not structural in nature. All reinforcing was placed in the plug to help prevent and limit cracking per $\mathrm{ACl}$ code.

The cracks are not expected to affect the durability of the concrete. As shown, the cracks only go a maximum of $5 / 8^{\prime \prime}$ into the plug. All reinforcing has a minimum 1.5 " clearance, so the reinforcing does not have exposure to any potential chemical or weathering attack.

NCHRP (National Cooperative Highway Research Program) 18-14 report "Evaluation and Repair Procedures for Precast/Prestressed Concrete Girders with Longitudinal Cracking in the Web" goes through the evaluation of cracking in bridge girders. 
The report suggests the following:

"Cracks narrower than $0.012 \mathrm{in.}$ may be left unrepaired. Cracks ranging from 0.012 to 0.025 in. should be repaired by filling the cracks with approved specialty cementitious materials and the end four feet of the girder side faces coated with an approved sealant."

All cracks noted in AFS RH LLW-SNR-086 are in the range of the mentioned tolerances above. Oldcastle proposes to follow this same criteria, with the exception that the $0.012 \mathrm{in}$. tolerance be reduced to 0.01 in. to stay consistent with current job specifications. This criteria would read that anything narrower than $0.01 \mathrm{in}$. may be left unrepaired, and cracks ranging from $0.01 \mathrm{in}$. to $0.025 \mathrm{in}$. would be repaired by filling the cracks with an approved repair material. The $0.01 \mathrm{in}$. compared to the listed $0.012 \mathrm{in}$. crack criteria is more conservative. This is an approved method for state highway girders that are a structural item exposed to the elements, so Oldcastle feels it is a sufficient guideline for the plugs which are also exposed to the elements. The sealant on the girder faces is not included in the recommendation for the plugs since it is not related to cracks in the concrete.

Based on a request by BEA during BEA's visit to the Oldcastle site to look at the plugs included in AFS' SNR-086, for all plugs included in the SNR, all cracks located on the tops of the plugs and any cracks extending from the top of the plug to 1 foot below the top edge along the sides will also be repaired no matter what width.

Oldcastle recommends that JetSet Smooth material be used as the cementitious material for the crack repairs.

Mike Blackham, PE

Oldcastle Precast Engineering Manager

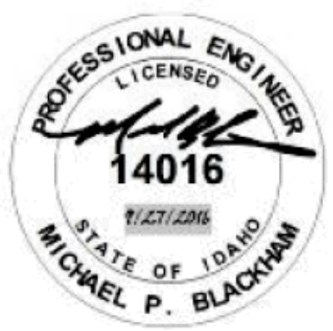

